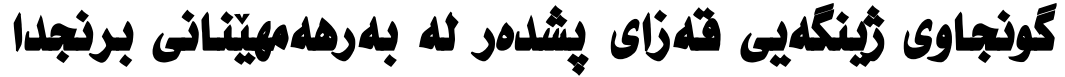

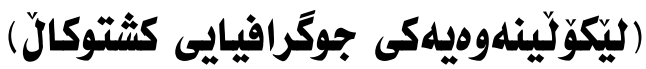

\section{لهزنجه صلاح عبدالله} بـاشى جوكرافيا، كوَليَّىى زانسته مروّثايهتييهكان، زانكوَى سليمانى، سليمانى، هـريّمى كوردستان، عيّراق. Lيمهاهل: Lanja.abdulla@univsul.edu.iq

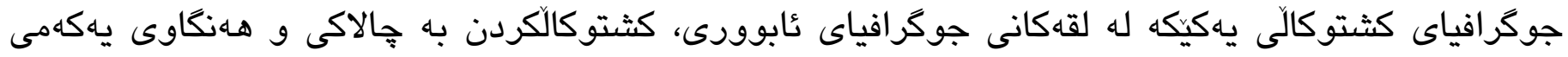

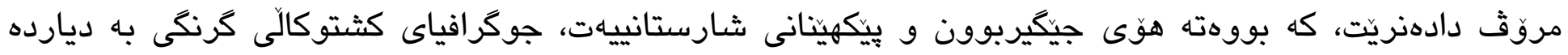

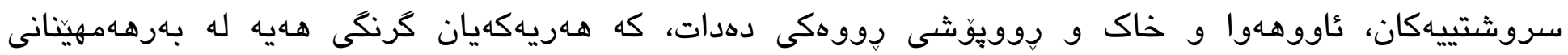

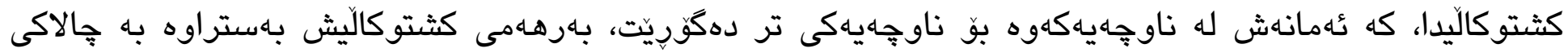

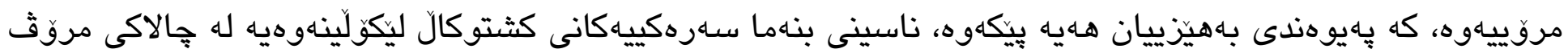

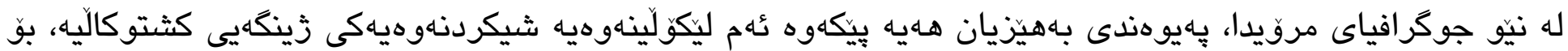

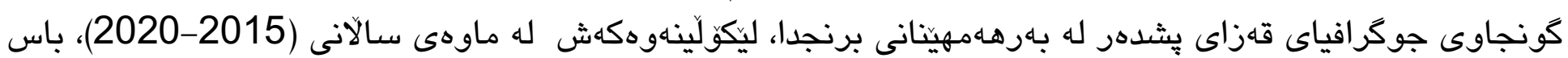

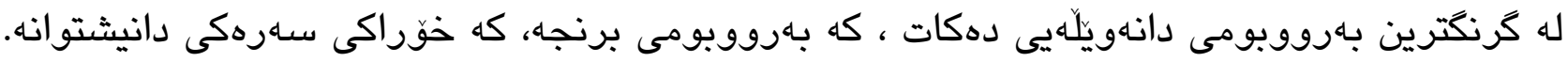

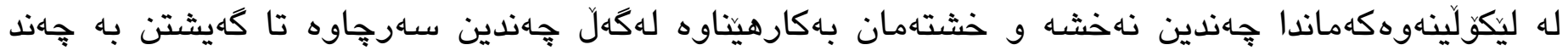

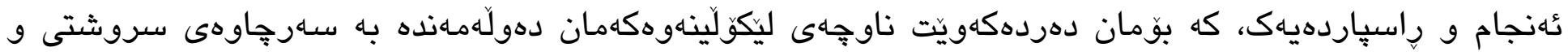

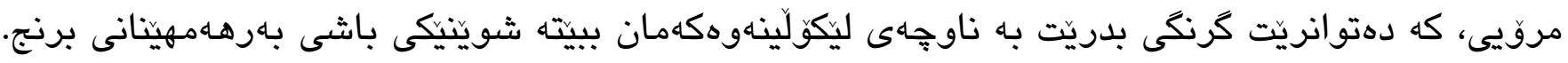

كايله وشُشكان: برنج، تاووهـوا، كثتوكال، بـرهـه، قهزاى يشدهر. 
جوكرافى ناسهان كثتوكالكردن به يهكيك له لقهكانى جوكرافيا دادهنين، كه كرنكى دهدات به ليكولَينهوهى

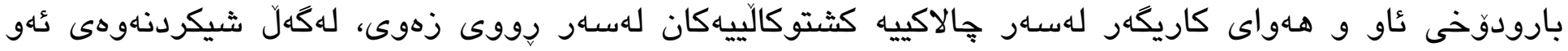

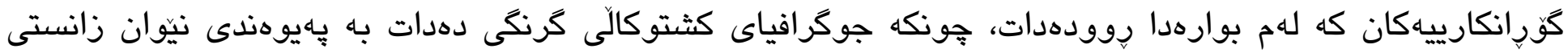

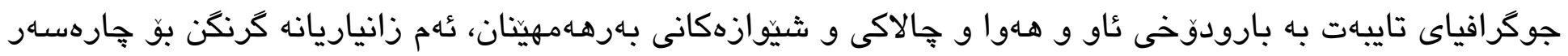

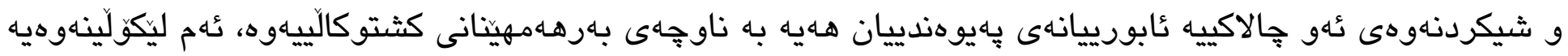

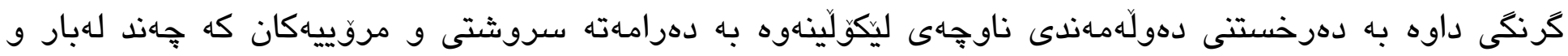

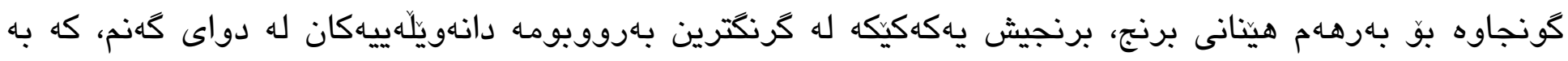

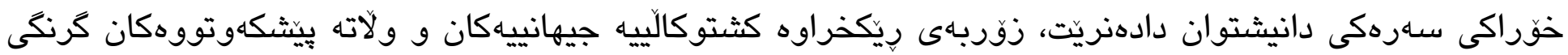

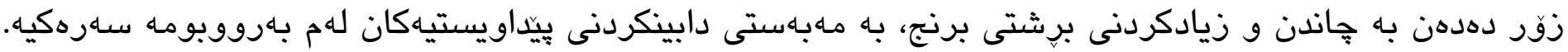

\section{كرنى ليكولَينهومكه:}

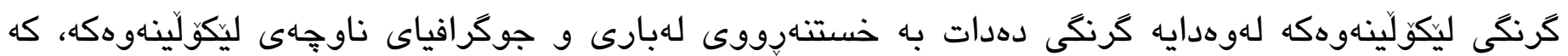

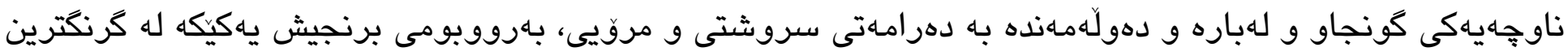

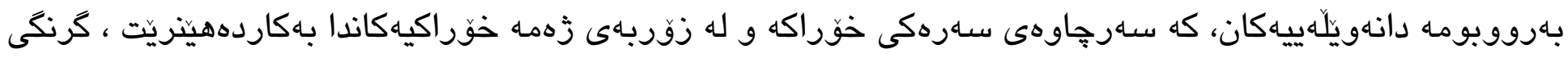

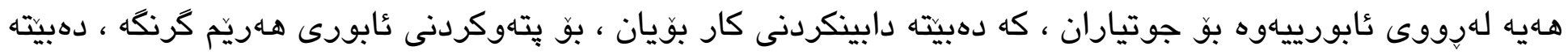

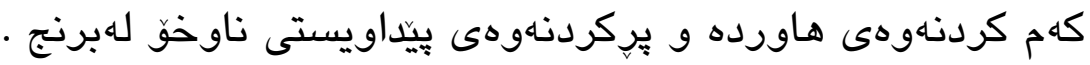

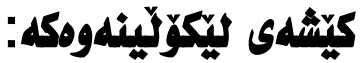

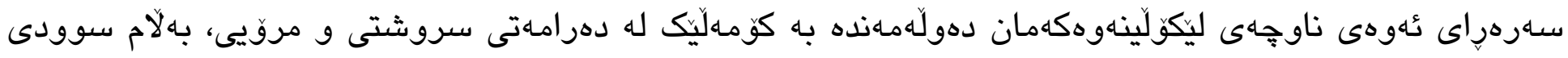

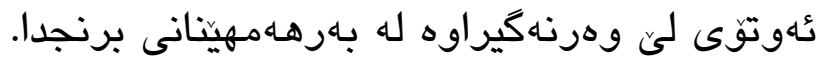

\section{كريماندى ليكوّلينهووكه:}

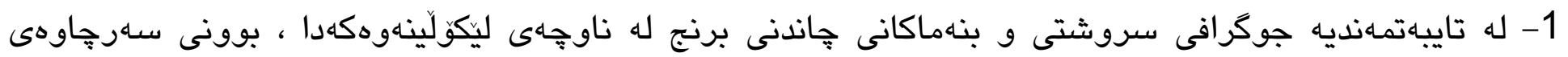

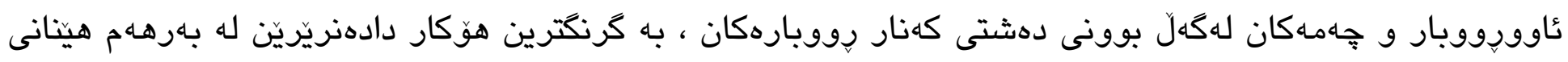

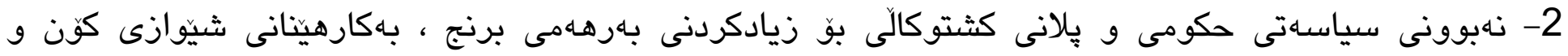

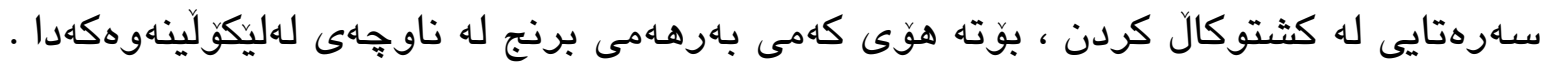

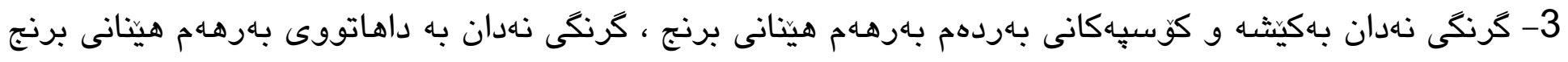

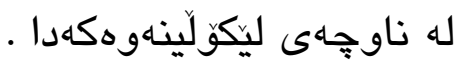




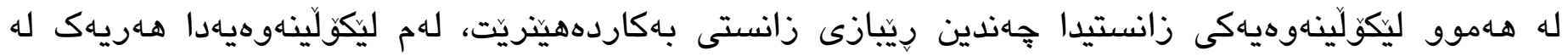

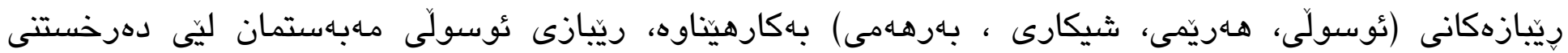

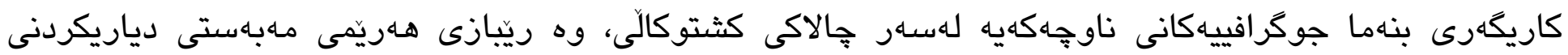

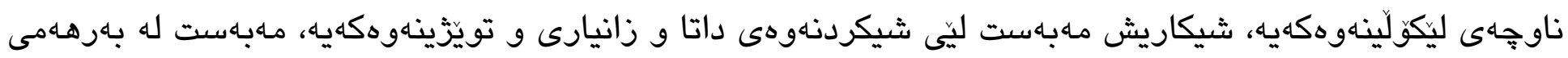

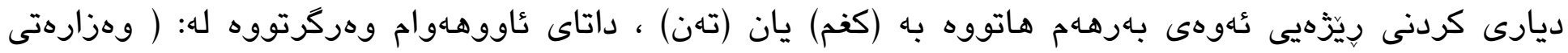

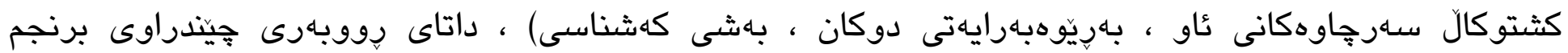

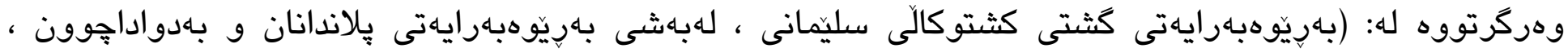

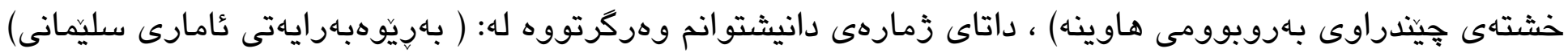

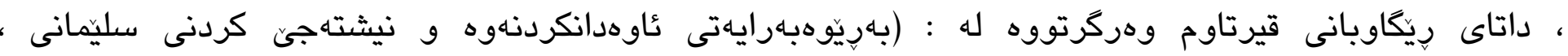

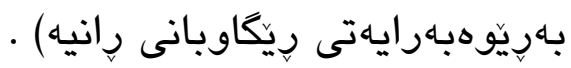

\section{نَامانجى ليكّولّينهومكه:}

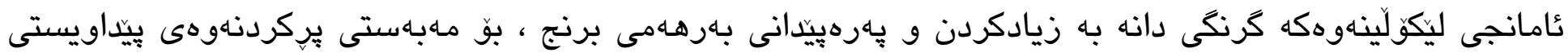

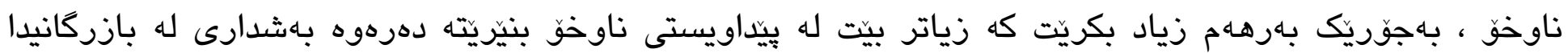
بكات.

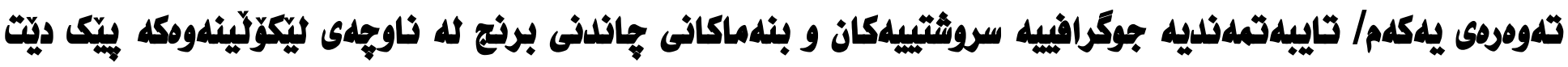

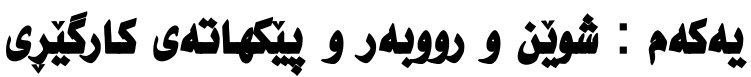

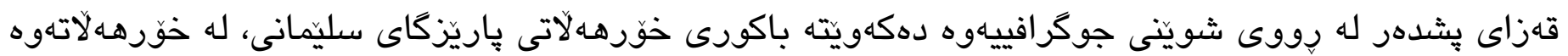

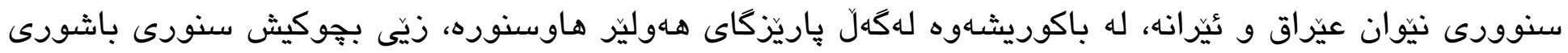

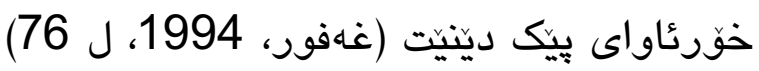

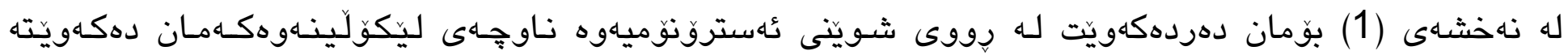

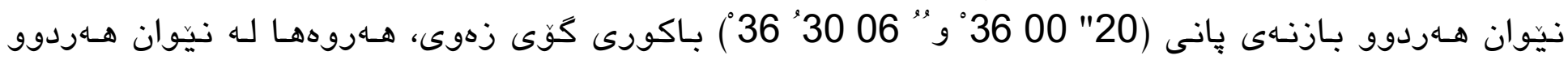

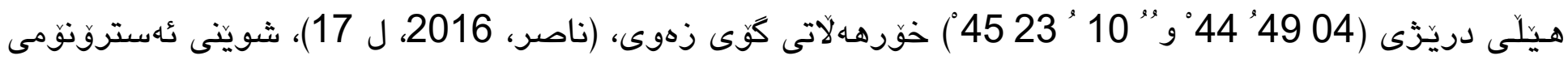

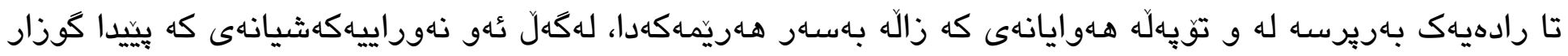

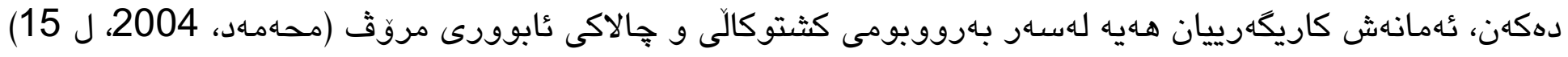




\section{نهخشهى (1) نهان}

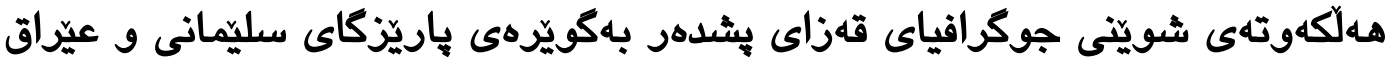

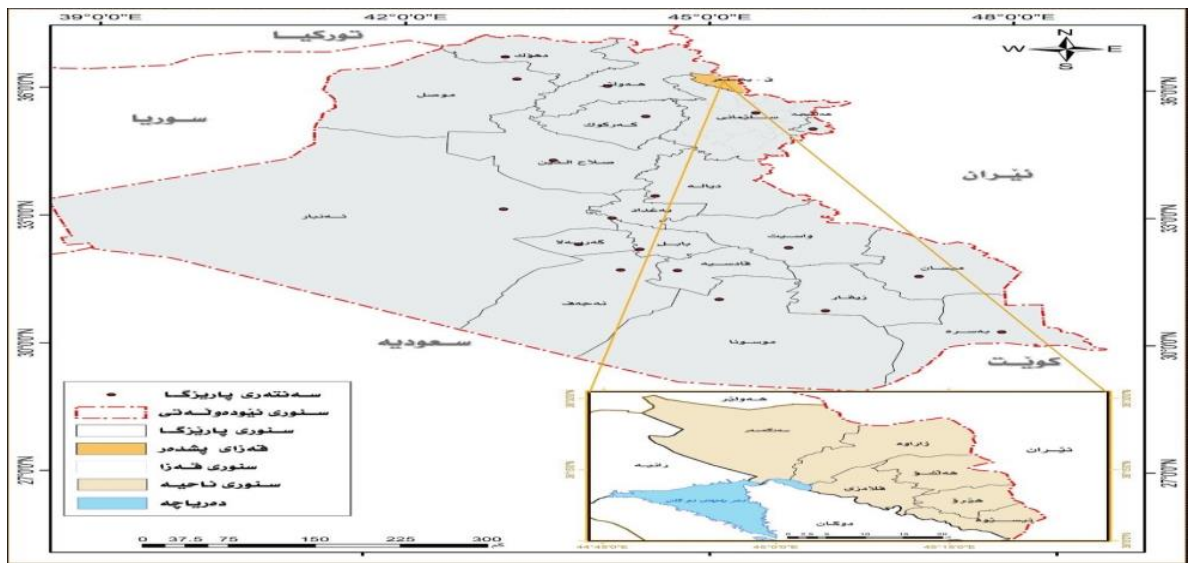

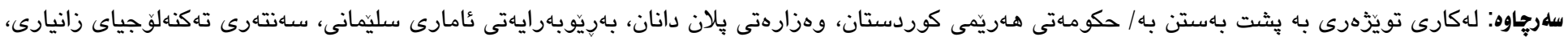
بهشى GIS، نهخشهى قهزاي بشدهر،

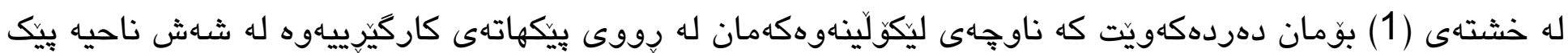

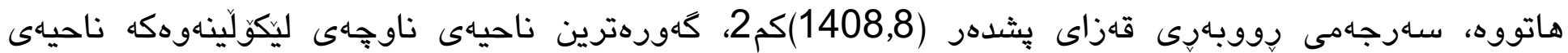

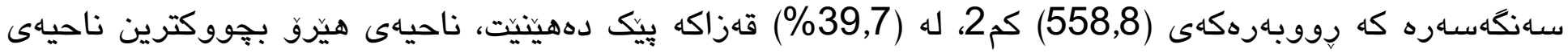

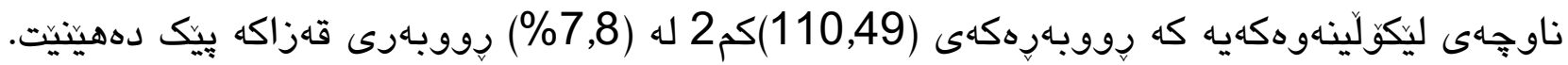

\section{خشتهى (1)}

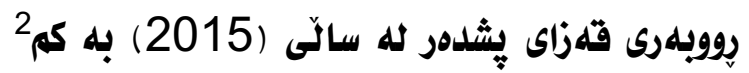

\begin{tabular}{|c|c|c|}
\hline ريّزّه لهسهر ئاستى سهرجهم قهزا & ניووبهر (كم²) & يهكه كاركيّرييهكان \\
\hline 39,7 & 558,8 & سهنكهارد \\
\hline 21,5 & 303,29 & ذراراوه \\
\hline 11,8 & 166,9 & هـالتشو \\
\hline 10,9 & 153,49 & سهانتهر (قهلادزيّ) \\
\hline 8,2 & 115,8 & ائيسيّوه \\
\hline 7,8 & 110,49 & هيَرق \\
\hline 100 & 1408,8 & سهرجهامى قهزا \\
\hline
\end{tabular}

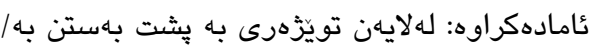
حكومة اقليم كوردستان، مديرية احصاء السليمانية، المؤشرات السكانية والبني الخدمية الارتكازية لاقليم كوردستان العراق، لسنة 2002، بـانه محافظة السليمانية 2003، غير منشورة، ص 3-4

\section{دووم : نُاو و هلوا}

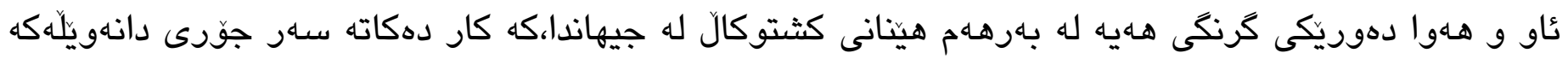

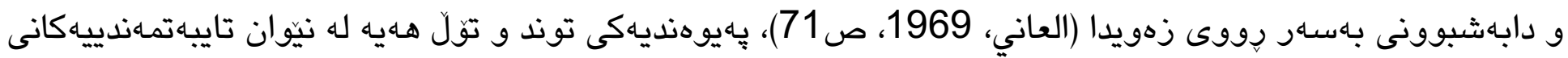

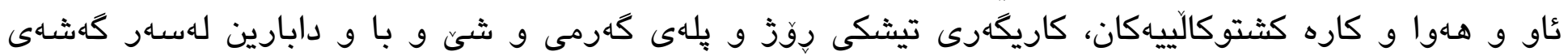




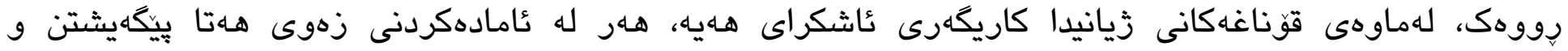

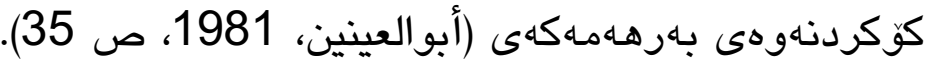

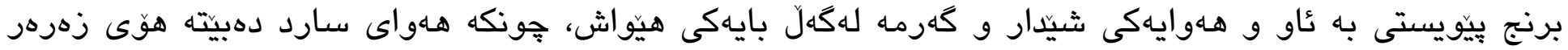

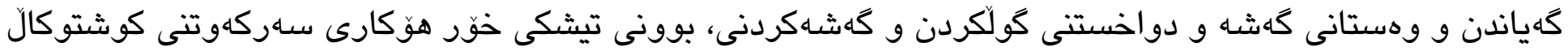

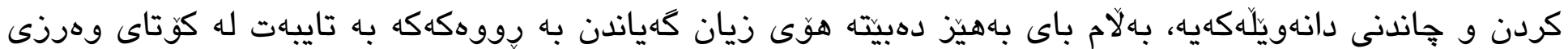
كَشهدا ( شفيق و الدبابي، 2008، صانك

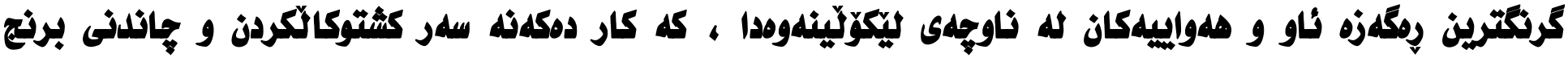

تيشكى خوّر ياخود رِووناكى يهكيكه له كرنكترين هوَكارهكان بو كهشهى روووهك (العانى،1969،ص 73)، برنج

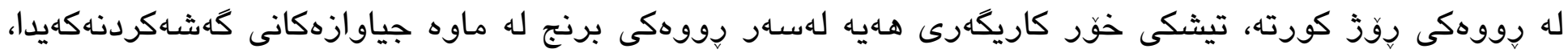

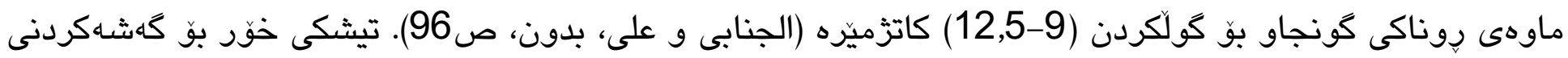

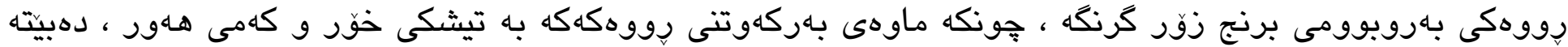

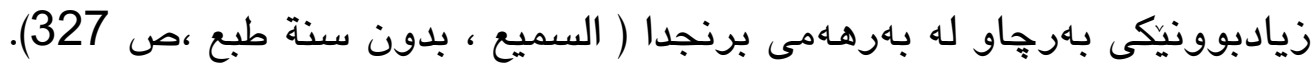

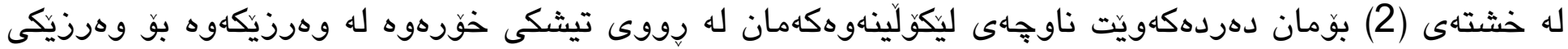

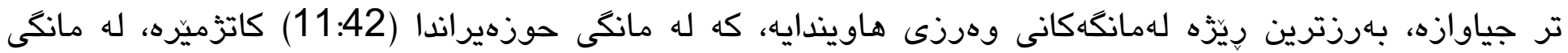

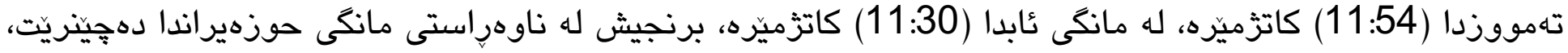

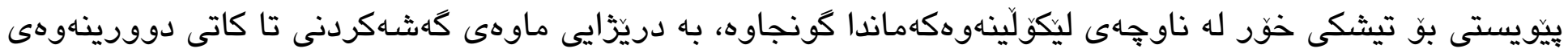

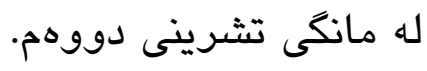

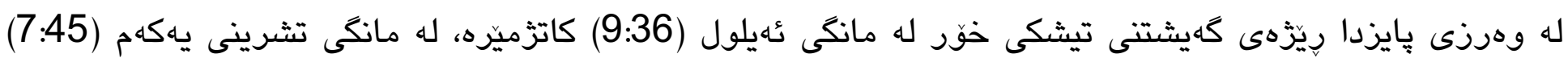

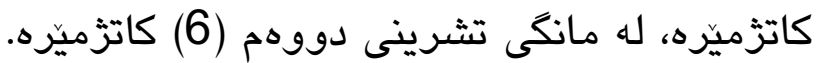

ته (2)

تيّكراى مانكانه و وهرزانه و سالآنهى بهركلهوتنى تيشكى خوّر (كاتثميّر) له قهزاى يشدهر له نيّوان سالآنى (2006-2015)"

\begin{tabular}{|c|c|c|c|c|c|c|c|c|c|c|c|c|c|}
\hline \multirow{2}{*}{$\begin{array}{c}\frac{1}{4} \\
\frac{y}{y} \\
3 \\
3\end{array}$} & \multicolumn{3}{|c|}{ زستان } & \multicolumn{3}{|c|}{ پֶايز } & \multicolumn{3}{|c|}{ هاوين } & \multicolumn{3}{|c|}{ بههار } & \multirow{2}{*}{ 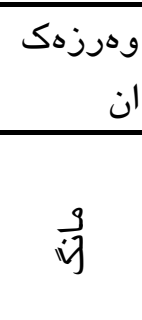 } \\
\hline & 尘. & $\begin{array}{l}y \\
3 \\
3\end{array}$ & $\begin{array}{cc}y \\
3 \\
3 & y\end{array}$ & 县 & 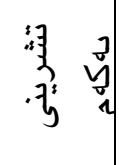 & 䎑: & J. & 䍂 & $\begin{array}{c}1 \\
0 \\
0 \\
3 \\
3.5\end{array}$ & 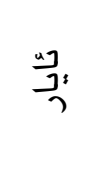 & 刑' & $\frac{m_{7}}{2}$ & \\
\hline$\stackrel{\substack{\infty \\
\stackrel{h}{\sim}}}{ }$ & $5: 30$ & $\begin{array}{c}4: 3 \\
0\end{array}$ & $4: 48$ & 6 & $7: 24$ & $9: 36$ & $11: 30$ & $11: 54$ & $11: 42$ & 8:54 & 8 & 5:48 & 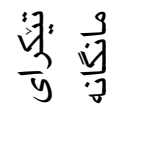 \\
\hline
\end{tabular}




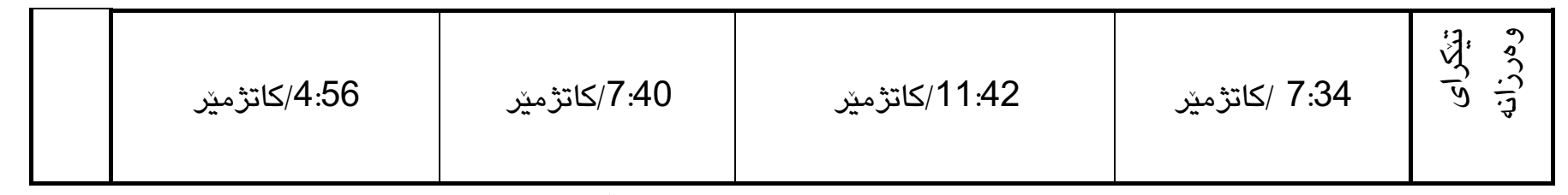

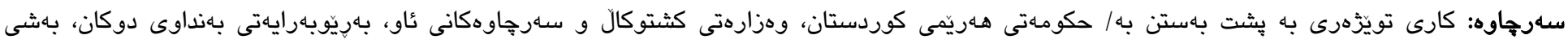

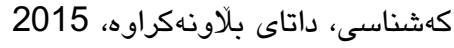

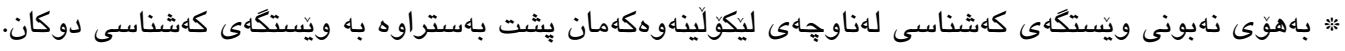

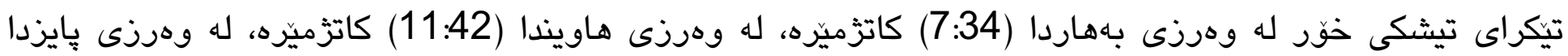

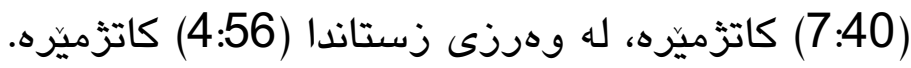

\section{2}

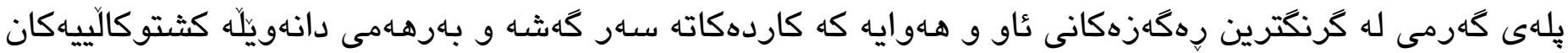

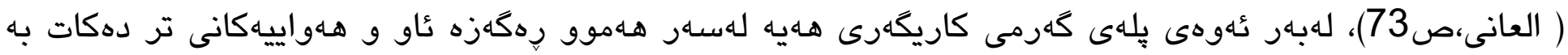

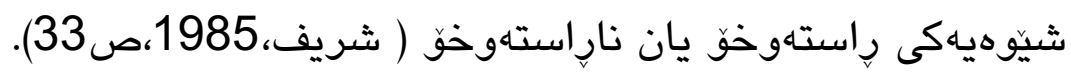

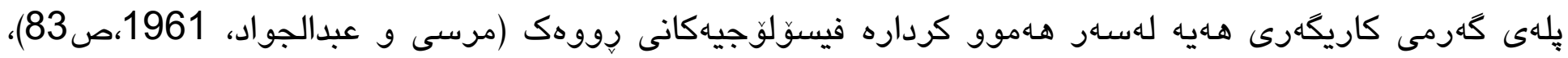

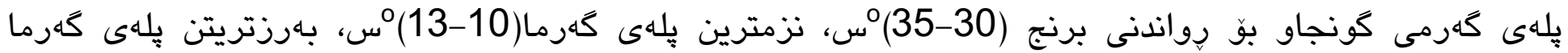

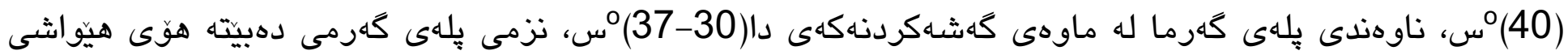

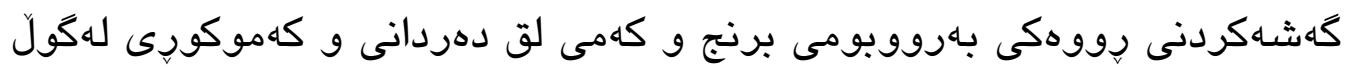

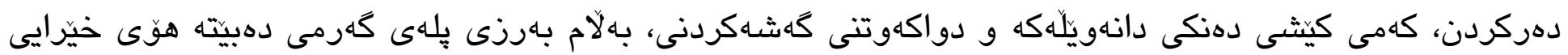

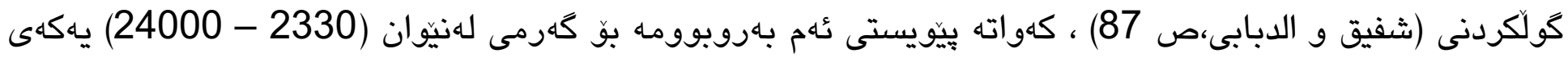

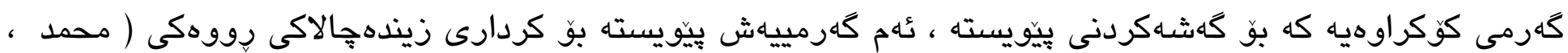

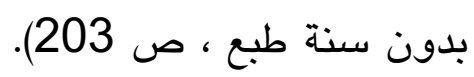

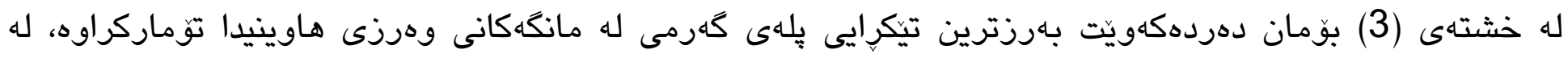

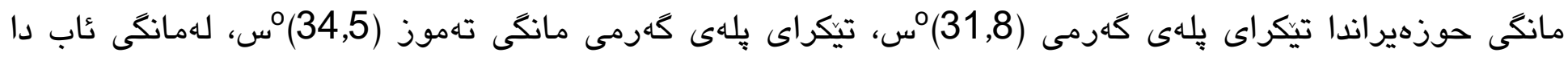

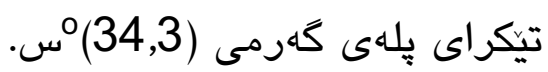

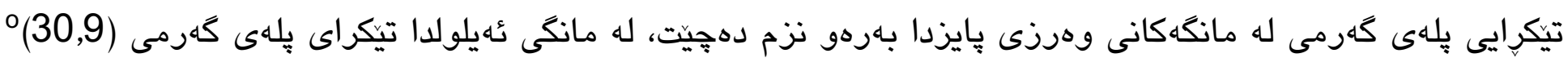

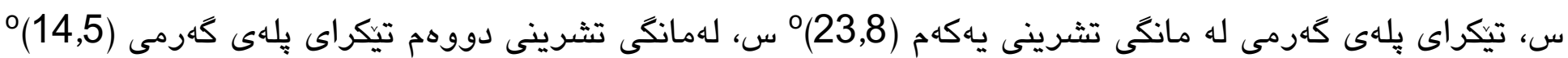




\section{خثتهى (3)}

تيّكراى مانكانه و ودرزانه و سالآنهى بِلهى كَرمى (س5) له قهزاى يشدهر له ماوهى سالآنى (2006-2015)".

\begin{tabular}{|c|c|c|c|c|c|c|c|c|c|c|c|c|c|}
\hline \multirow{2}{*}{$\begin{array}{l}\frac{1}{y} \\
\frac{3}{y} \\
\frac{3}{3}\end{array}$} & \multicolumn{3}{|c|}{ زستان } & \multicolumn{3}{|c|}{ پايز } & \multicolumn{3}{|c|}{ هاوين } & \multicolumn{3}{|c|}{ بهار } & 角 \\
\hline & 尘 & $\begin{array}{l}y \\
\frac{1}{3} \\
y \\
3 \\
3 \\
0 \\
2\end{array}$ & $\begin{array}{l}y \\
y \\
y \\
y \\
\vec{y} \\
y \\
2\end{array}$ & 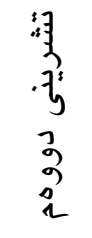 & 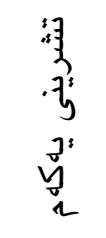 & 等: & $\stackrel{a}{J}$. & $\begin{array}{l}3 \\
3 \\
3\end{array}$ & $\begin{array}{r}2 \\
0 \\
3 \\
3 \\
3\end{array}$ & 先; & 管: & $\stackrel{\frac{a}{2}}{\frac{2}{2}}$ & $\overrightarrow{\mid \vec{v}}$ \\
\hline \multirow{2}{*}{$\stackrel{\infty}{\text { in }}$} & 8,2 & 6,7 & 9,4 & 14,5 & 23,8 & 30,9 & 34,3 & 34,5 & 31,8 & 24,4 & 17,9 & 12,9 & $\begin{array}{l}\text { 翠 } \\
\frac{1}{y}\end{array}$ \\
\hline & \multicolumn{3}{|c|}{8,1} & \multicolumn{3}{|c|}{23,07} & \multicolumn{3}{|c|}{33,5} & \multicolumn{3}{|c|}{18,4} & 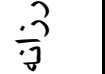 \\
\hline
\end{tabular}

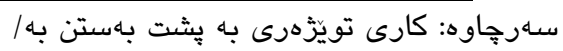

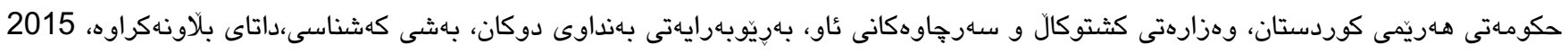

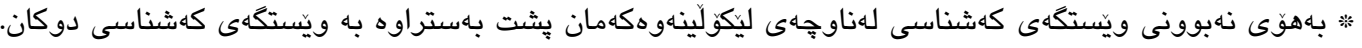

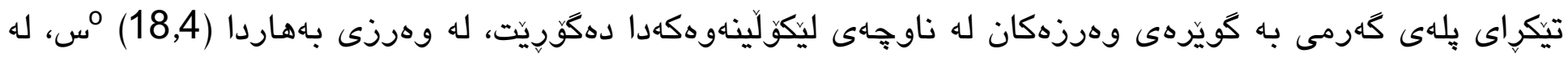

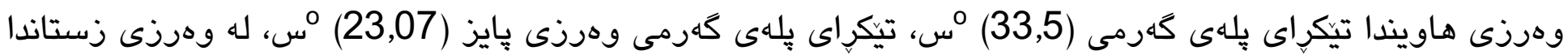

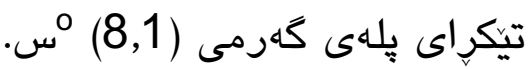

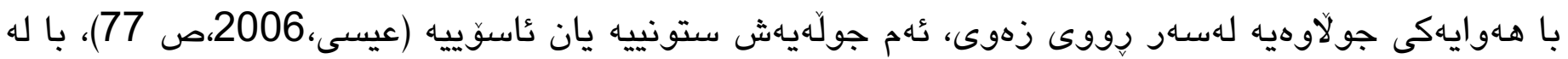

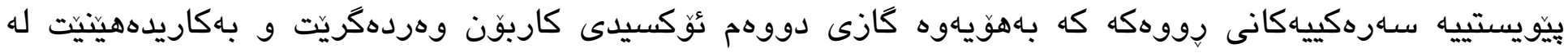

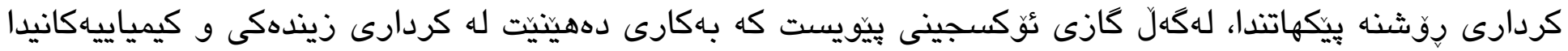

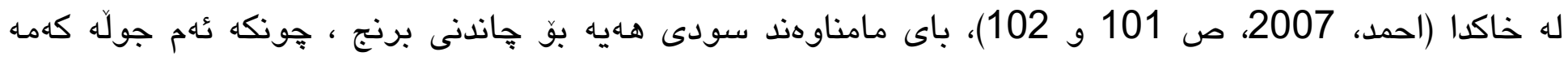

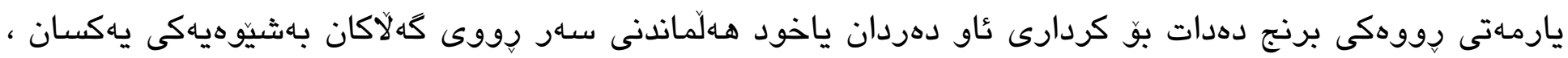

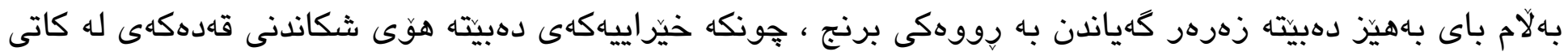

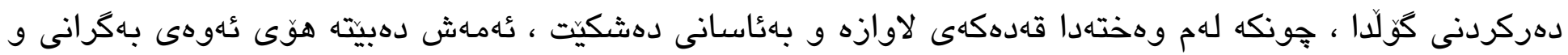

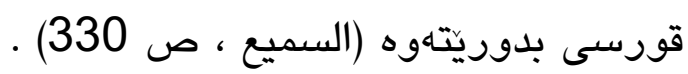

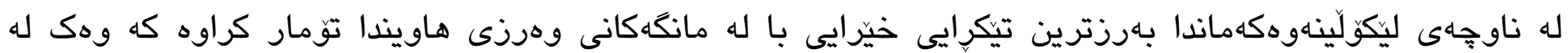

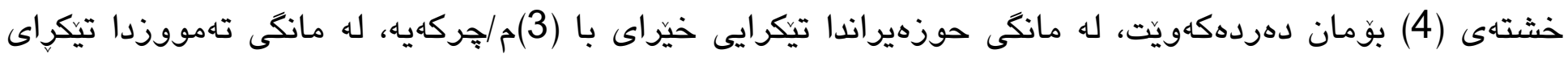

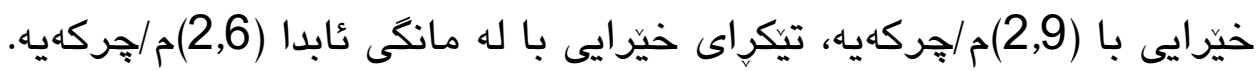




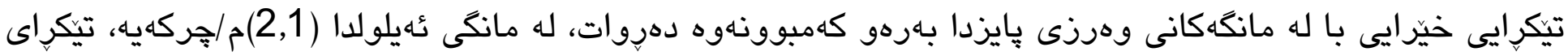

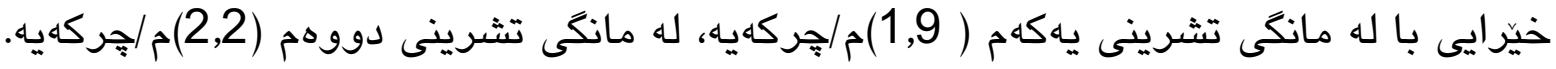

\section{خشتهى (4)}

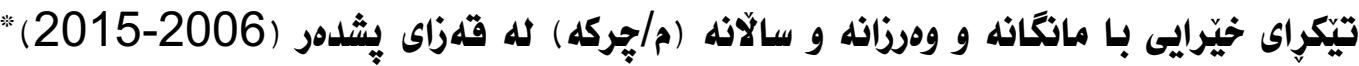

\begin{tabular}{|c|c|c|c|c|c|c|c|c|c|c|c|c|c|}
\hline تيكّي الانه & \multicolumn{3}{|c|}{ زستان } & \multicolumn{3}{|c|}{ يايز } & \multicolumn{3}{|c|}{ هاوين } & \multicolumn{3}{|c|}{ به هار } & وهرزهكان \\
\hline & 里 & $\begin{array}{l}y \\
3 \\
y\end{array}$ & $\frac{y}{3}$ & 缶 & 角 & 羿: & ]. & $\begin{array}{l}3 \\
\xi \\
\xi\end{array}$ & $\begin{array}{r}1 \\
0 \\
0 \\
3 \\
-3\end{array}$ & $\frac{a}{7} ;$ & 薢 & $\frac{a 7}{2}$ & مانخ \\
\hline \multirow[t]{2}{*}{2,45} & 2,5 & 1,9 & 2,2 & 2,2 & 1,9 & 2,1 & 2,6 & 2,9 & 3 & 2,5 & 2,6 & 3 & تيكّراي \\
\hline & \multicolumn{3}{|c|}{2,2} & \multicolumn{3}{|c|}{2,1} & \multicolumn{3}{|c|}{2,8} & \multicolumn{3}{|c|}{2,7} & وهرزانه \\
\hline
\end{tabular}

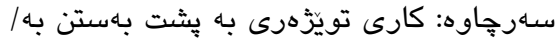

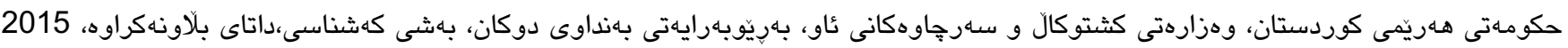

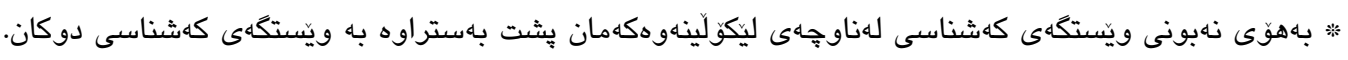

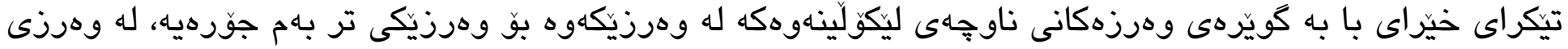

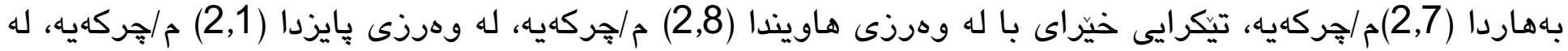
وهرزى زستاندا (2,2) م/ هركهيه.

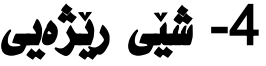

هـلّمى تُاو له رهكَزه ئاووهـواييه كرنكهكانه، جهونكه هوَى دروستبوونى جههندين دياردهى كهش وهـهواييه

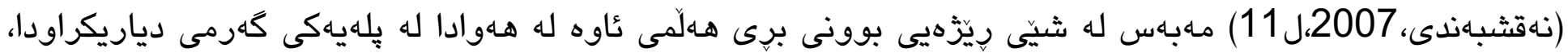

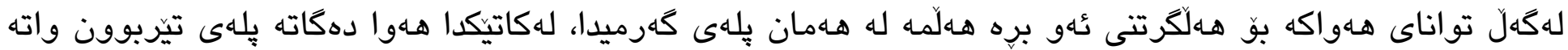

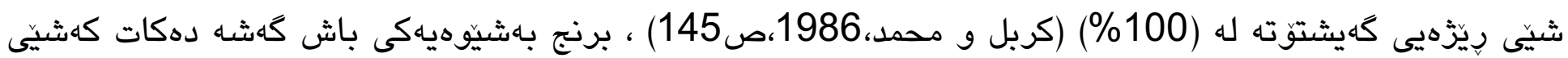

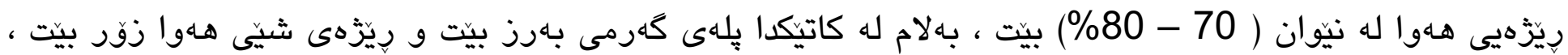

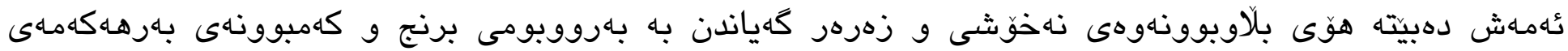

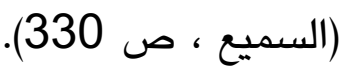

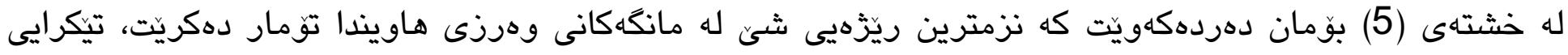

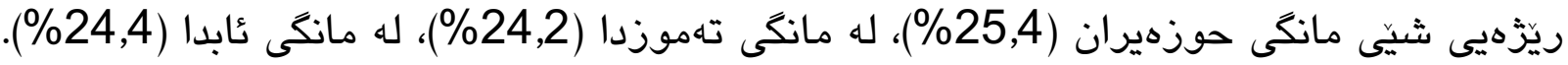

\section{خشتهى (5)}




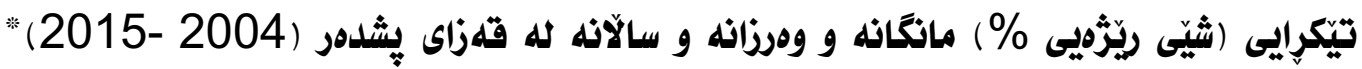

\begin{tabular}{|c|c|c|c|c|c|c|c|c|c|c|c|c|c|}
\hline \multirow{2}{*}{ 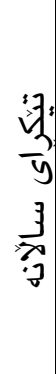 } & \multicolumn{3}{|c|}{ زستان } & \multicolumn{3}{|c|}{ بايز } & \multicolumn{3}{|c|}{ هاوين } & \multicolumn{3}{|c|}{ بههار } & وهرزهك \\
\hline & 里 & $\begin{array}{l}y \\
13 \\
3 \\
3 \\
3 \\
0 \\
2 \\
2\end{array}$ & 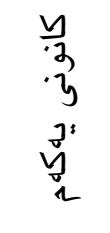 & $\begin{array}{l}3 \\
3 \\
3 \\
3 \\
3 \\
3 \\
2 \\
2\end{array}$ & 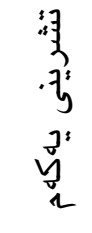 & 䎑 & J. & 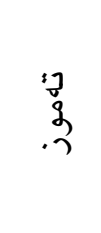 & 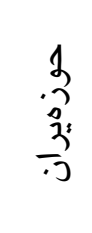 & ב & 争: & $\stackrel{\frac{a}{2}}{\frac{2}{2}}$ & $\vec{b}$ \\
\hline \multirow[t]{2}{*}{$\begin{array}{c}\hat{6} \\
0 \\
0\end{array}$} & 65,4 & 68,6 & 62,5 & 58,4 & 38,8 & 25,7 & 24,4 & 24,2 & 25,4 & 42,1 & 55,1 & 57,5 & $\frac{4}{y}$ \\
\hline & \multicolumn{3}{|c|}{65,5} & \multicolumn{3}{|c|}{40,9} & \multicolumn{3}{|c|}{24,7} & \multicolumn{3}{|c|}{51,6} & رزانه \\
\hline
\end{tabular}

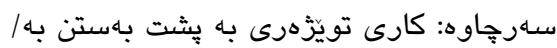

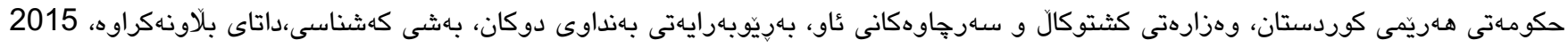

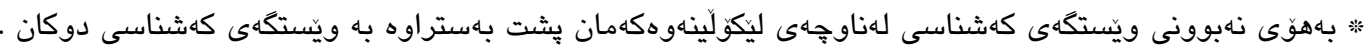

تيكرايى شيّى ريّزّهيى له مانكى عُهيلولى وهرزى بِايزدا (25,7\%)، له مانكى تشرينى يهكهم (38,8\%)، له مانكى تثرينى دووهم (58,4\%).

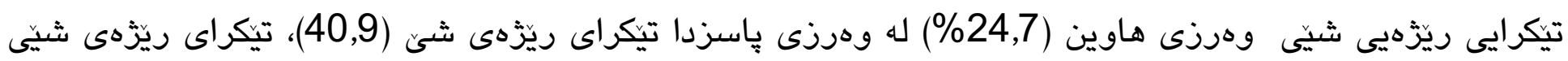

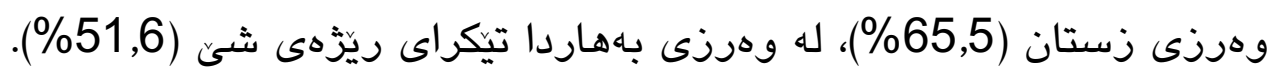

\section{"سخ يلهم : دمرامهذى ثُاو}

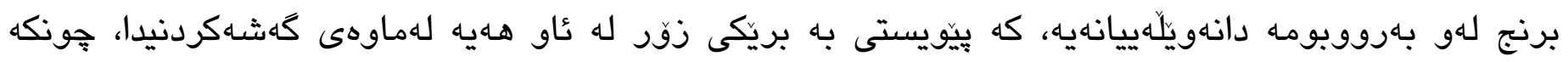

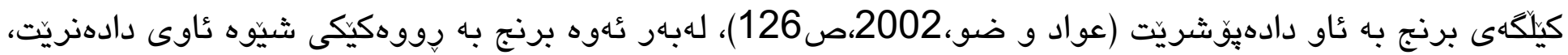

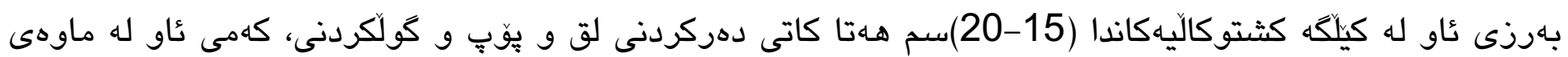

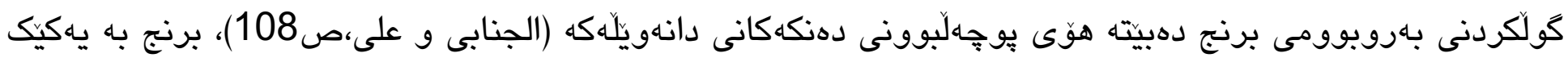

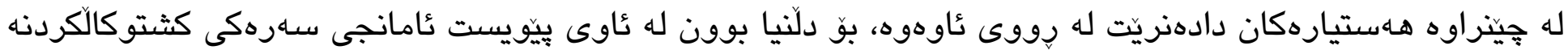

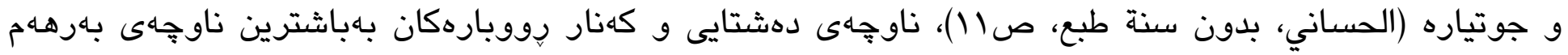

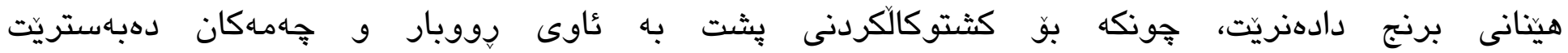

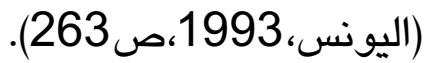

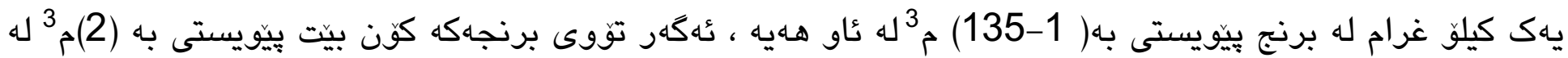
ئاو هاءيه.

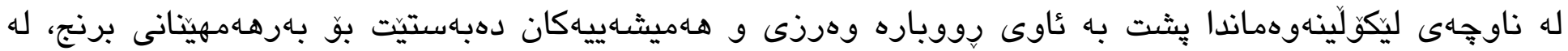

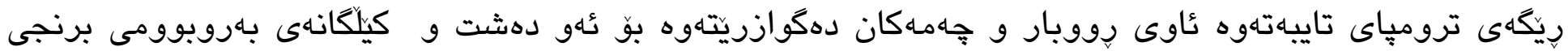

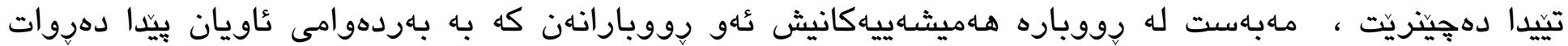

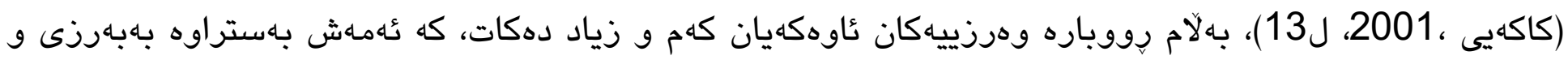

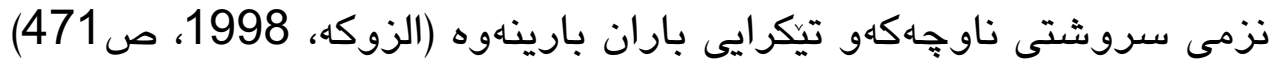


كرنكترين بوووباره هـميشهييهكانى ناوجهى ليكولينهوهكه بريتين له رِوويارى زيّى بجووك، كه يهكيكه له كرنكترين

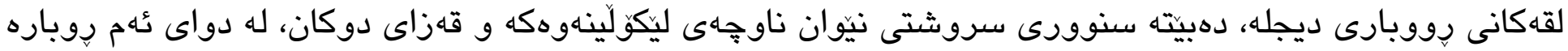

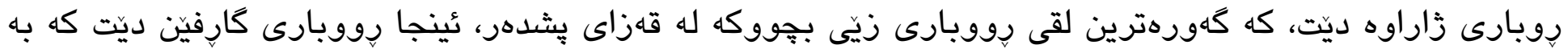

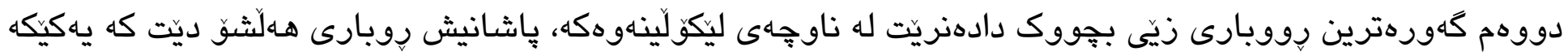

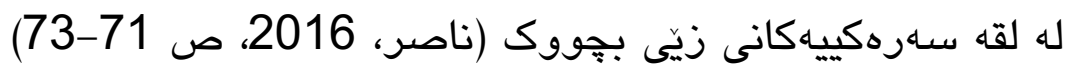

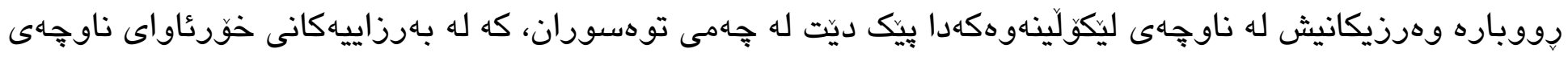

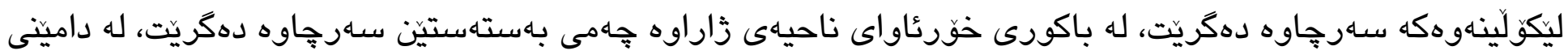

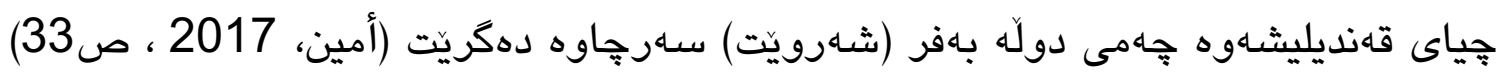

\section{هوارمم : بلهزئ و تزمى دِووى زموى}

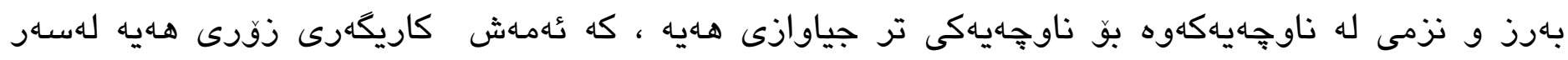

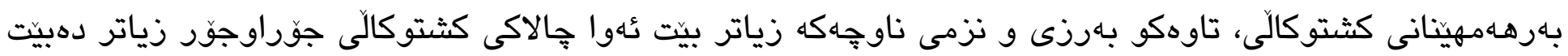

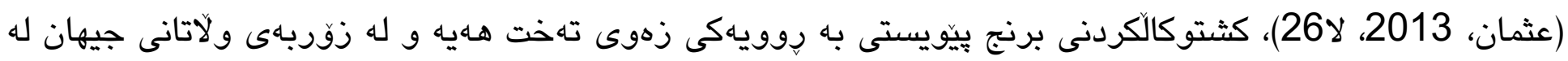

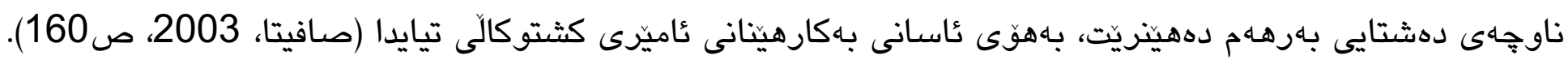

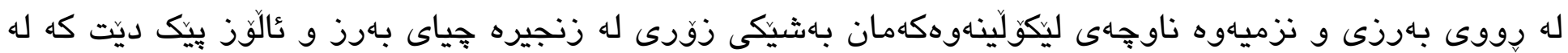

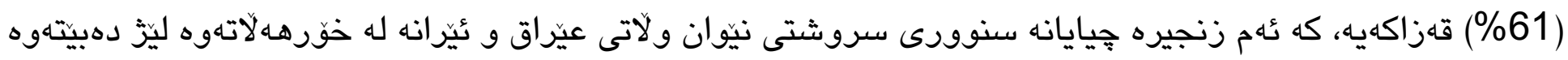

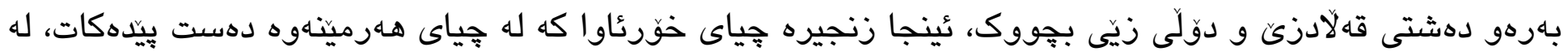

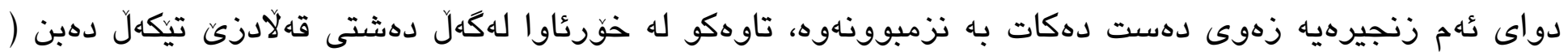

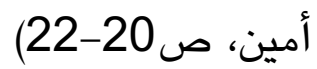

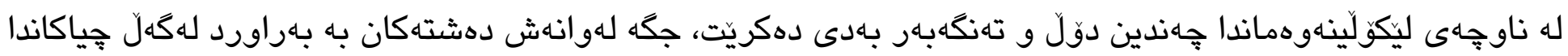

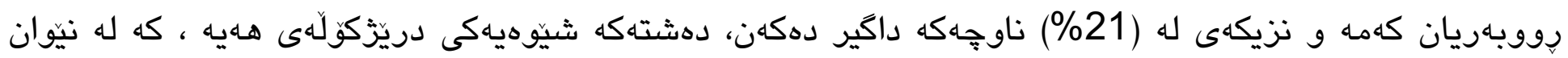

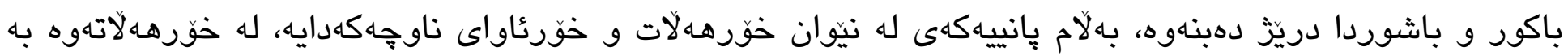

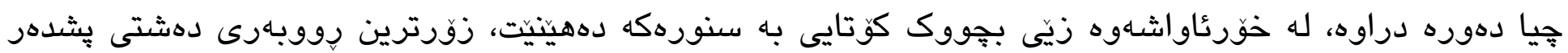

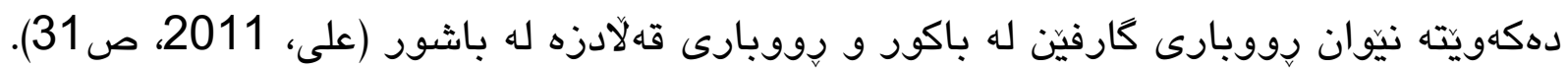

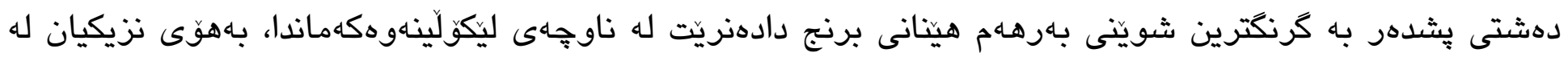

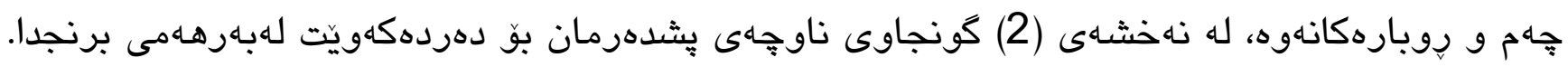

\section{نه نهل (2)}




\section{كَونجاوى ناوجهى يُشدر بوّ بهرهلمى برنج}

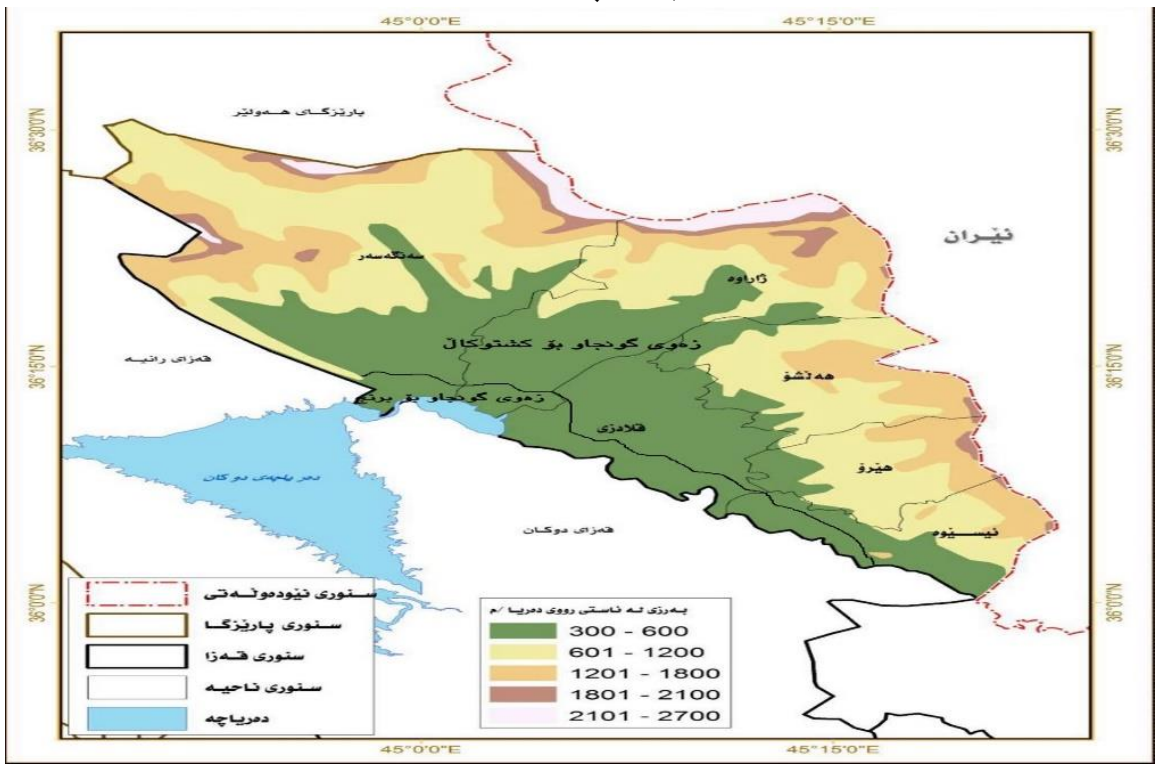

سهرجاوه: لهارى تويَّرهىى به بشارتت بهستن بها

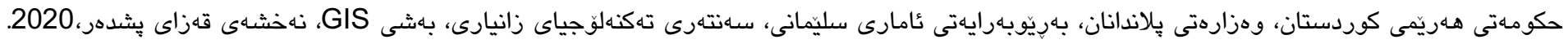

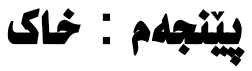

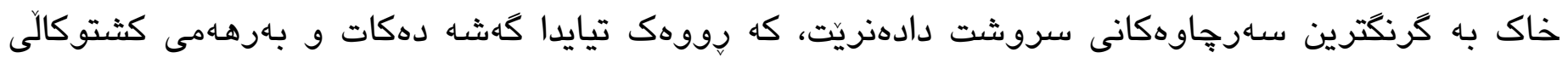

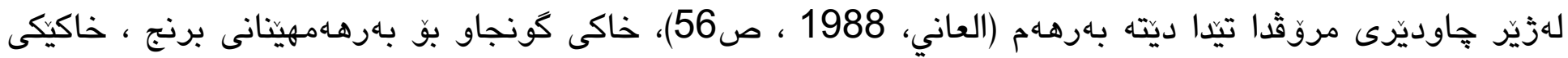

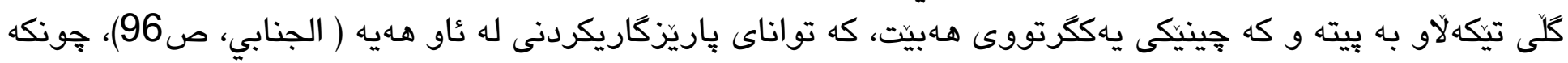

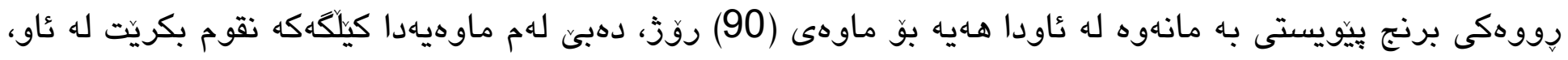

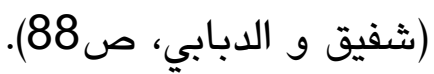

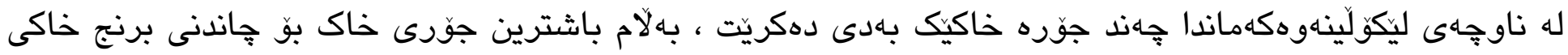

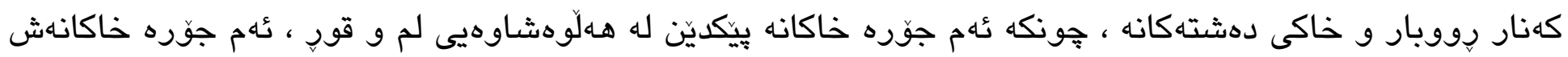

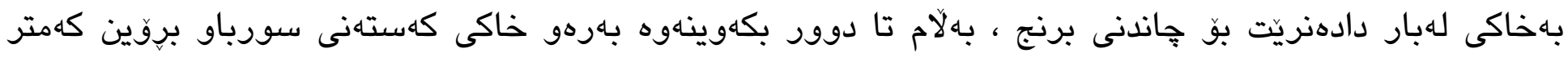

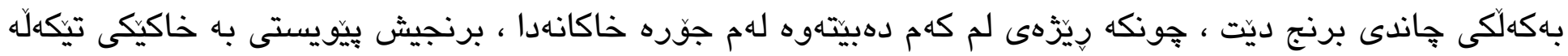

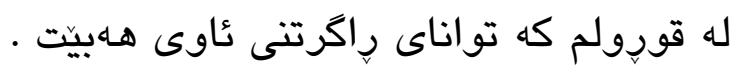

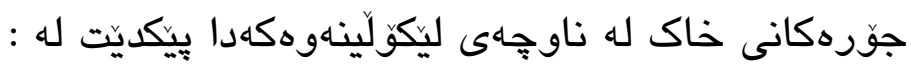

\section{1 - خاكى ناوجه سله خت و بلهرزكان:}

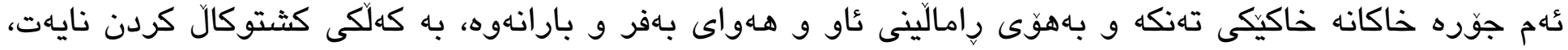

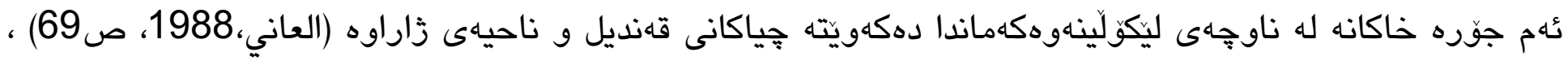

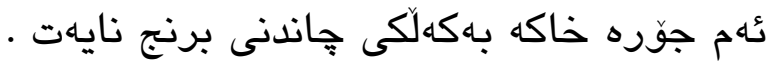

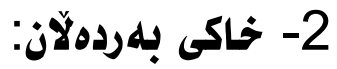




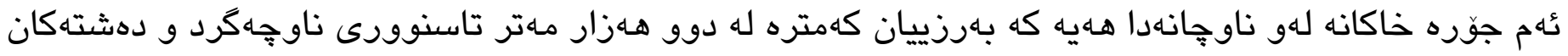

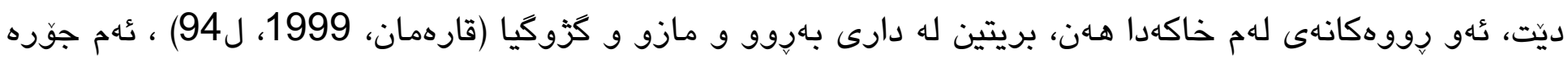

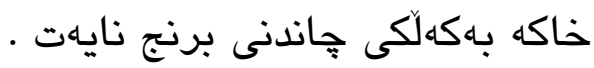
3- خاكى كهنار رِووبارهكاز:

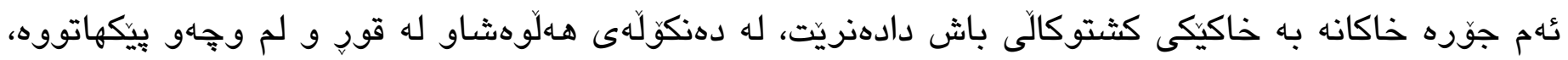

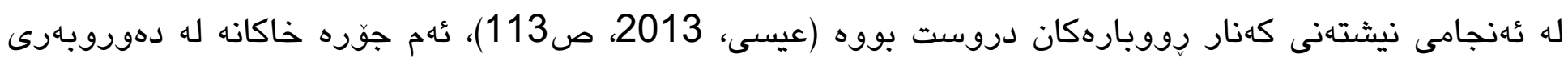

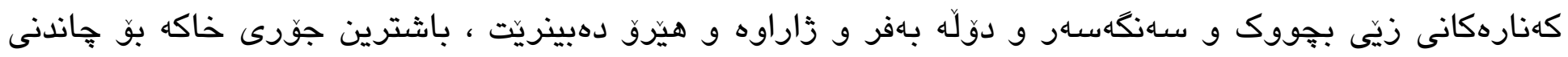
برنج.

\section{4- خاكى دهشتهكان:}

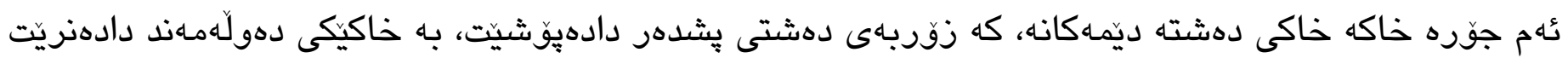

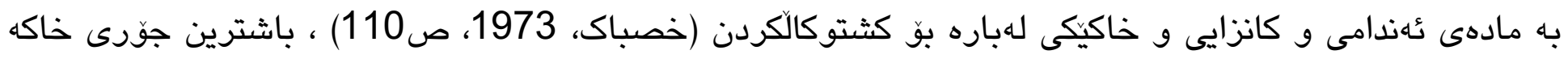
بوّ جِاندنى برنج.

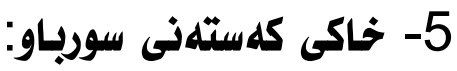

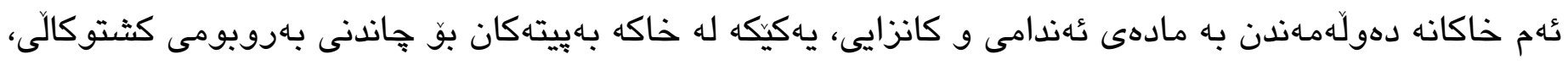

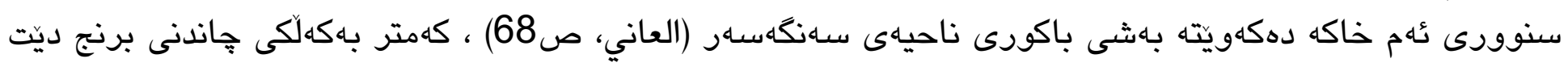

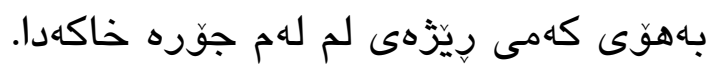

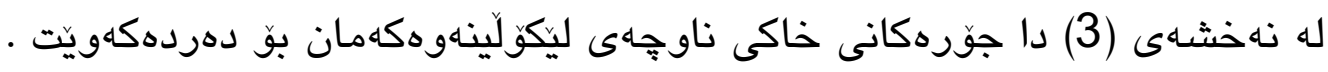

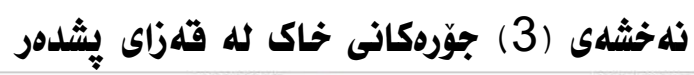

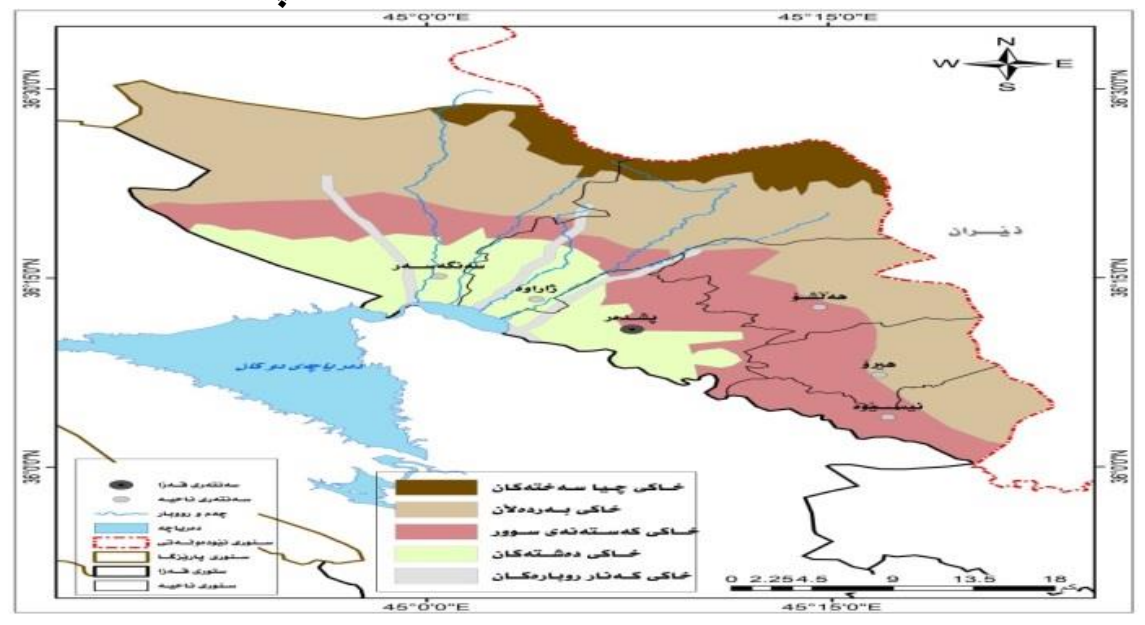

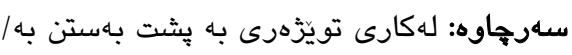

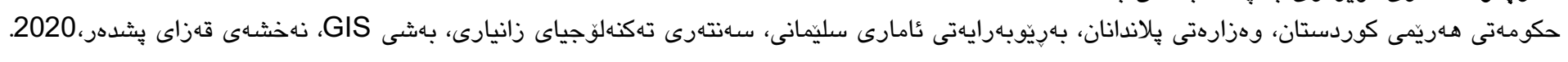

\section{تلdومرهى دووهم}




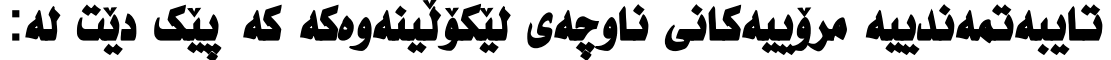

\section{يلهكم : داثيشتوان}

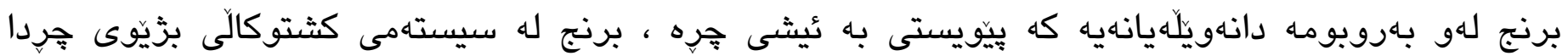

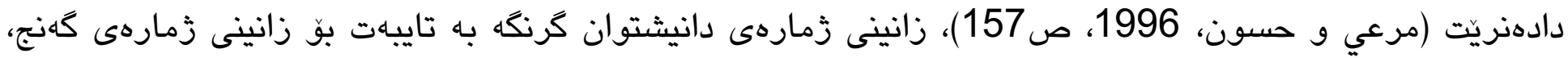

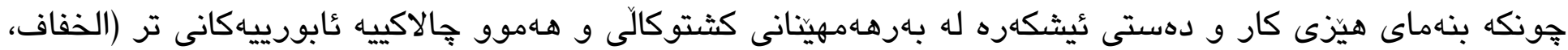

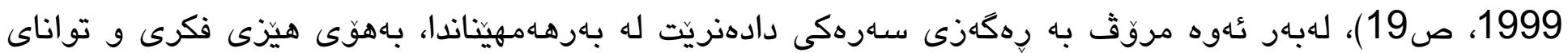

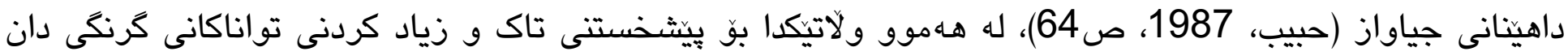

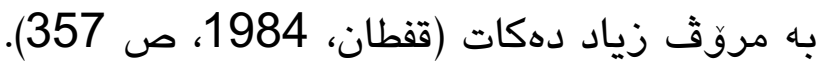

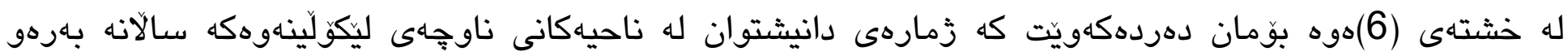

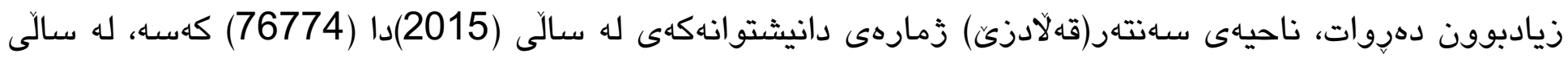

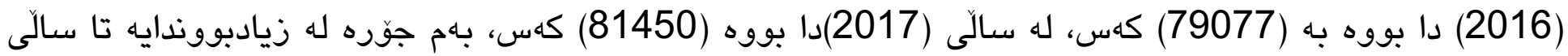
(2020) بووه به (89002) دأ بوده به (8916) كهس.

\section{خشتهى (6)}

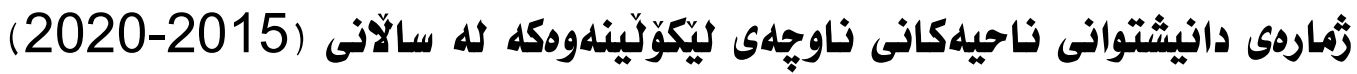

\begin{tabular}{|c|c|c|c|c|c|c|}
\hline \multicolumn{6}{|c|}{ سال } & \multirow{2}{*}{ ناحيهكان } \\
\hline 2020 & 2019 & 2018 & 2017 & 2016 & 2015 & \\
\hline 89002 & 86410 & 83893 & 81450 & 79077 & 76774 & سـهنتهر \\
\hline 2259 & 2193 & 2129 & 2067 & 2007 & 1949 & هيَّقُ \\
\hline 10115 & 9820 & 9534 & 9256 & 8987 & 8725 & هـاهُشَقو \\
\hline 17021 & 16525 & 16034 & 15576 & 15123 & 14682 & زاراوه \\
\hline 27586 & 26783 & 26003 & 25245 & 24510 & 23796 & سـانكَّهـار \\
\hline 2955 & 2869 & 2786 & 2705 & 2626 & 2549 & كيسيسيوه \\
\hline 148938 & 144600 & 140379 & 136299 & 132330 & 128475 & كوى كثتى \\
\hline
\end{tabular}

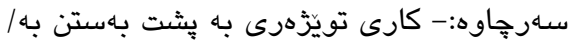

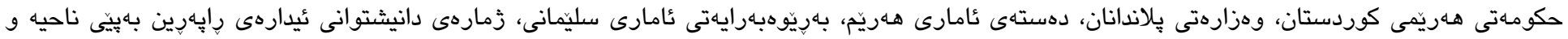

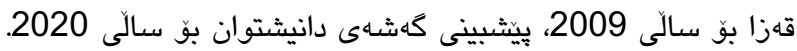

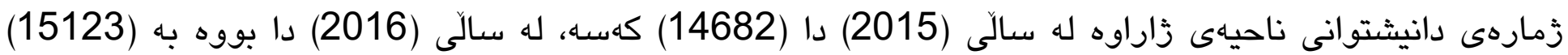

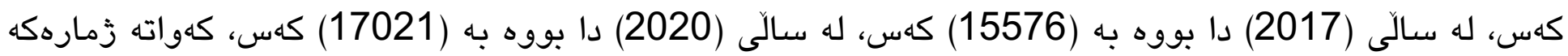

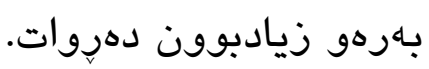

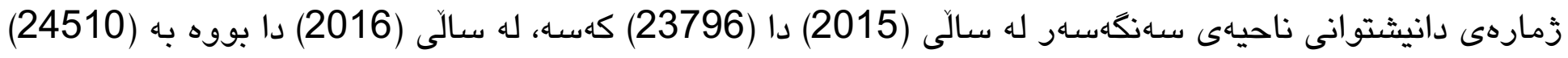

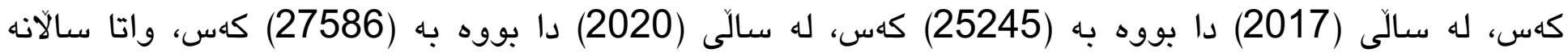
زمارهكه له زيادبووندايه. 


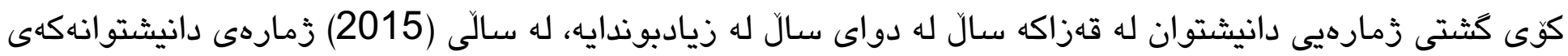

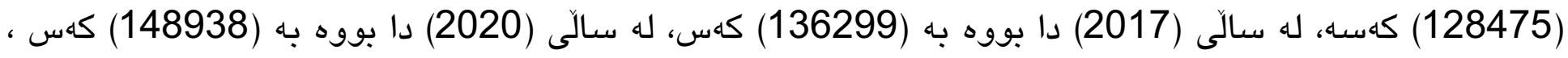

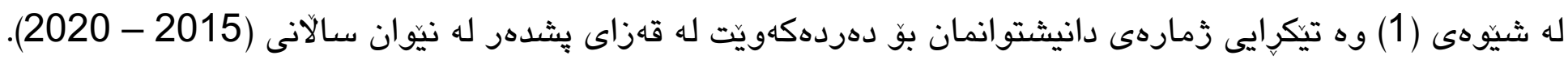

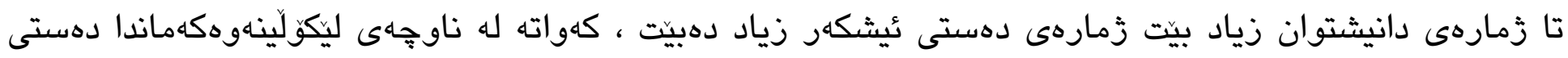

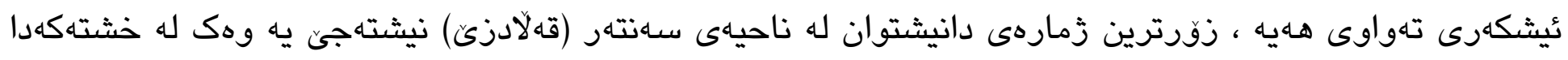

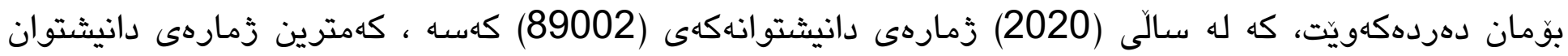

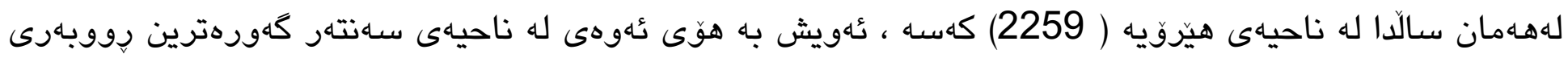

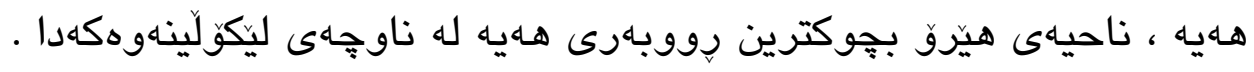

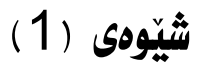

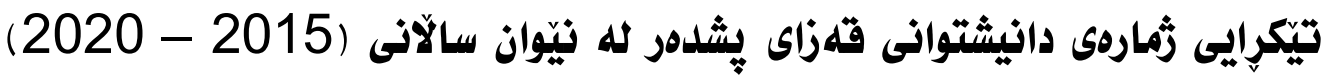

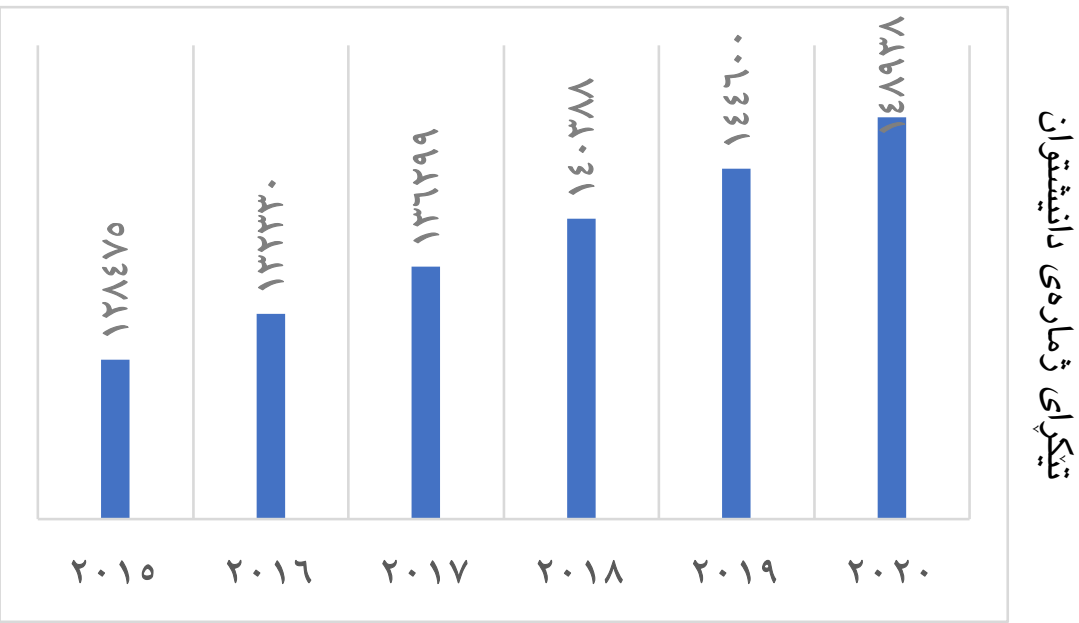

\section{سـال}

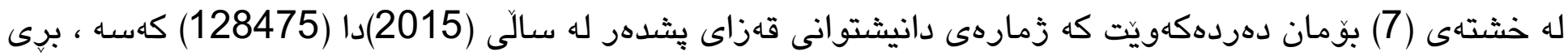

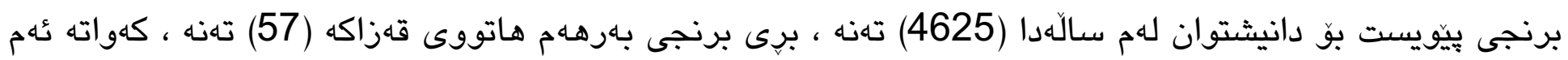

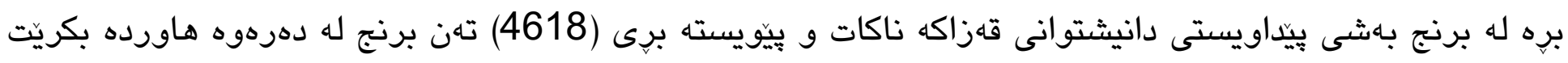

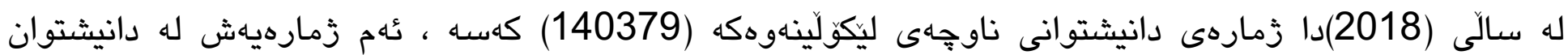

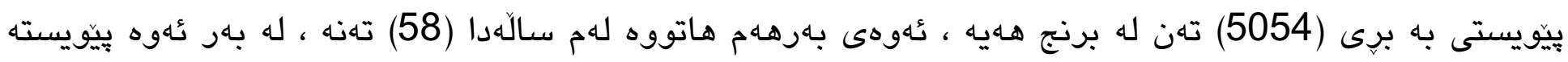

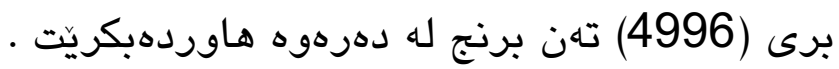

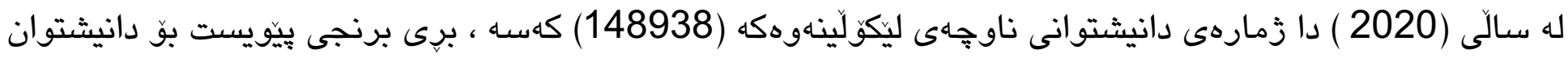

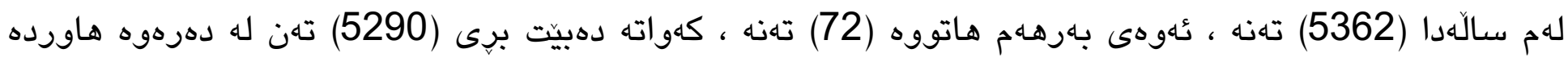

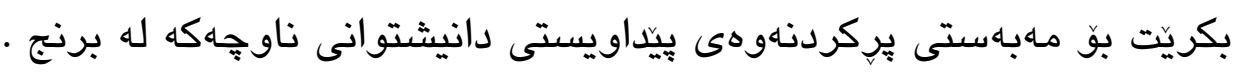

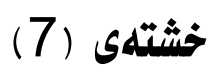

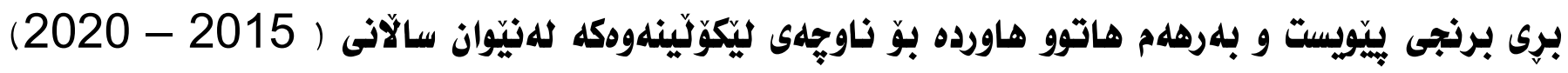




\begin{tabular}{|c|c|c|c|c|}
\hline برى برنج (تكن) & قبهرزاى بشى برنج (تهن) & برِى برنج (تهن) بيّيويست & قدارهى دانيشتوانى يشدهر & سال \\
\hline 4618 & 57 & 4625 & 128475 & 2015 \\
\hline 4706 & 58 & 4764 & 132330 & 2016 \\
\hline 4849 & 58 & 4907 & 136299 & 2017 \\
\hline 4996 & 58 & 5054 & 140379 & 2018 \\
\hline 5143 & 63 & 5206 & 144600 & 2019 \\
\hline 5290 & 72 & 5362 & 148938 & 2020 \\
\hline
\end{tabular}

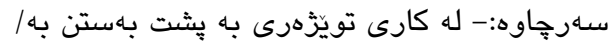

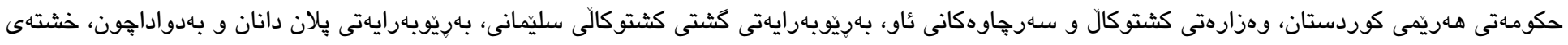

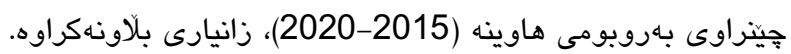

دووهم : سلهرمايد

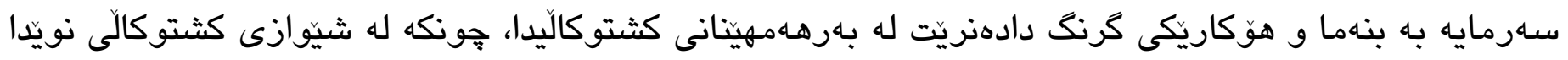

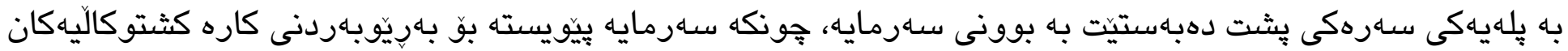

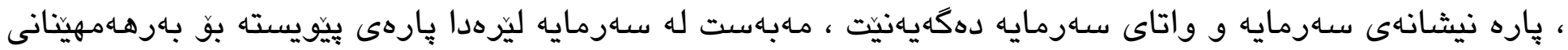

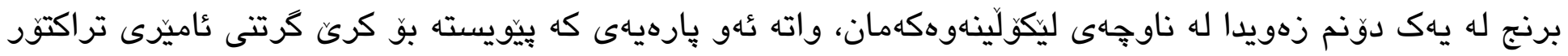

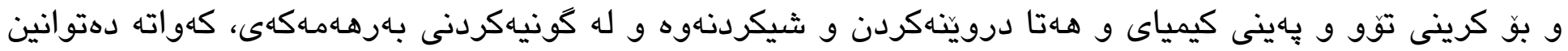

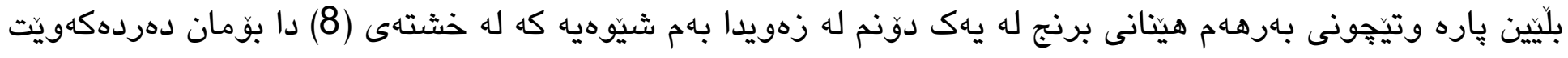

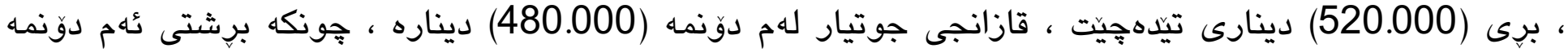

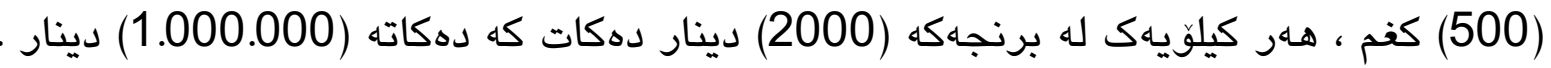

خشتهى (8)

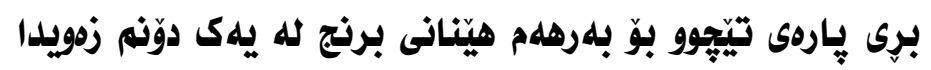

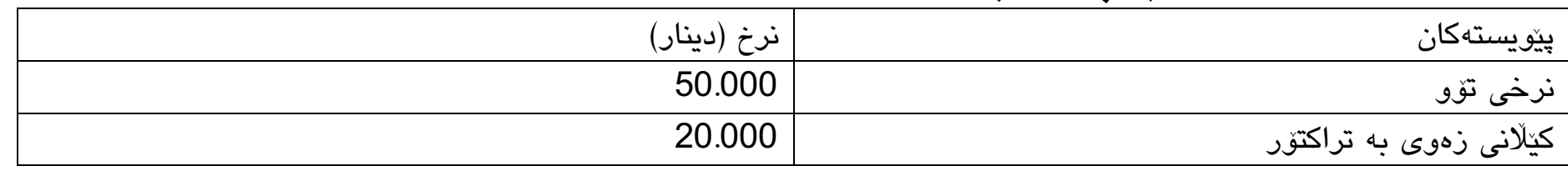




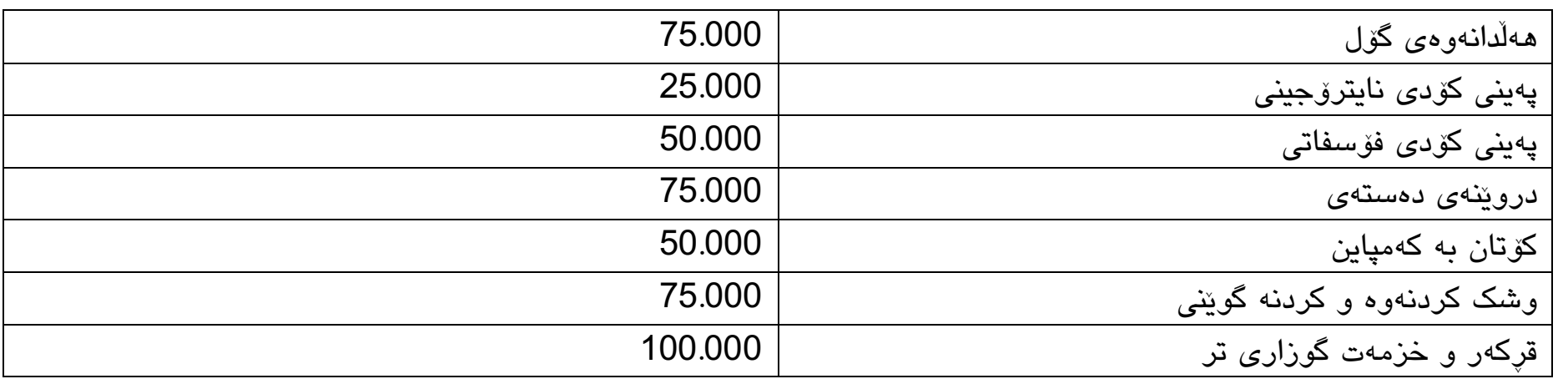

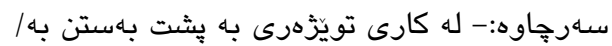

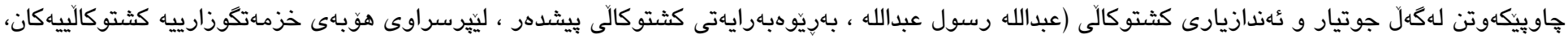
. (2020/8/1

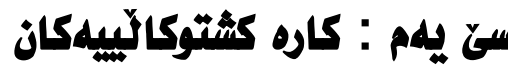

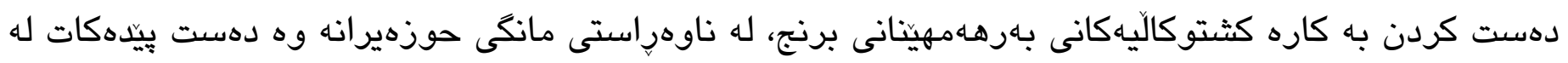

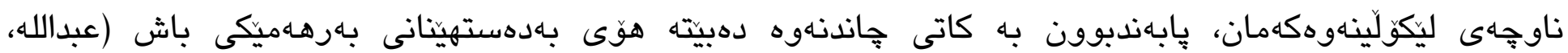

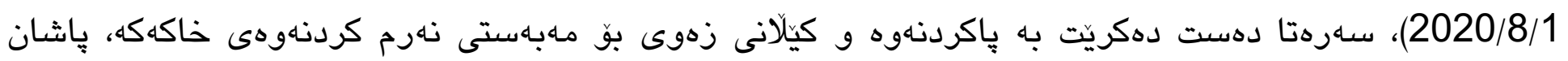

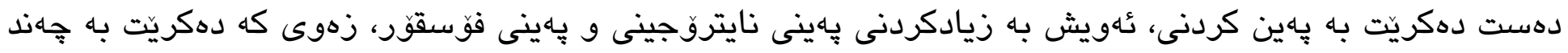

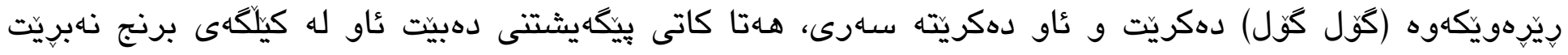

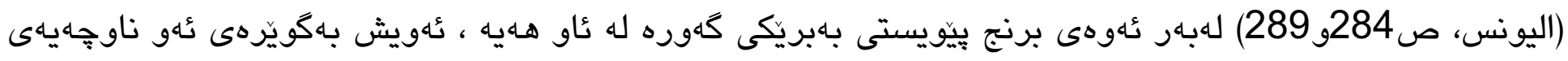

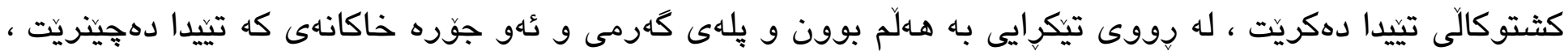

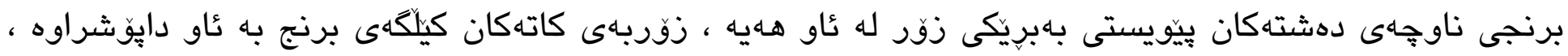

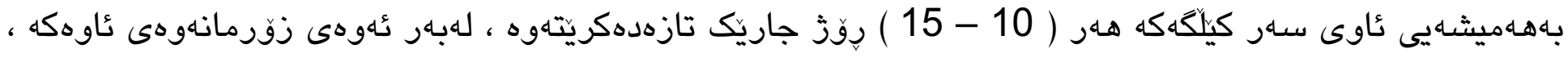

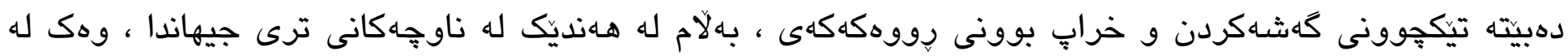

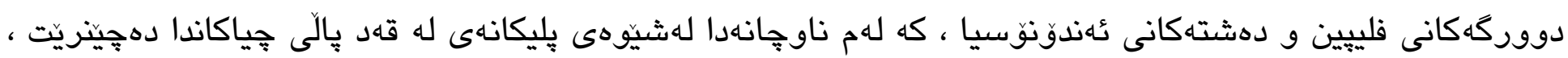

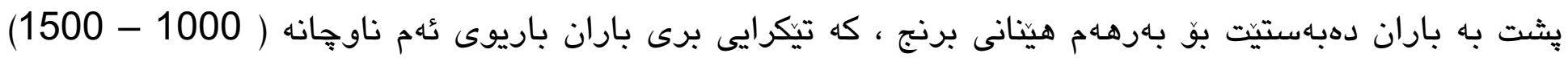

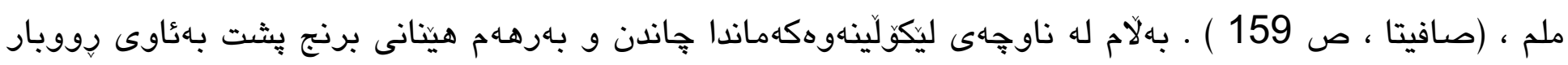

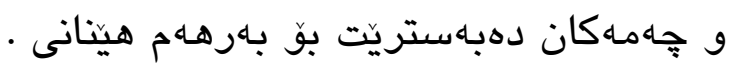

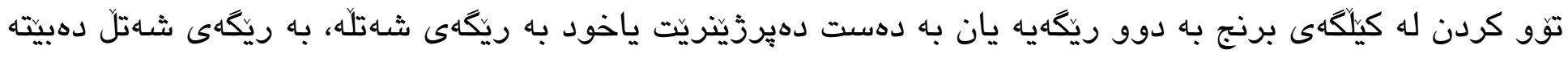

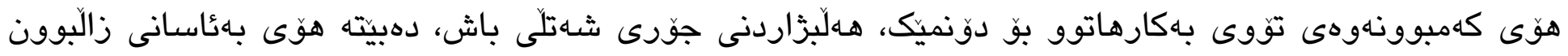

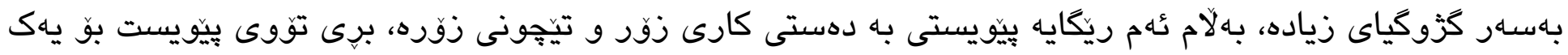

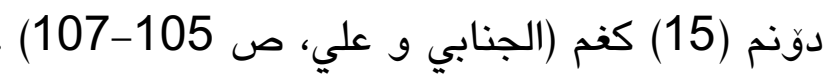

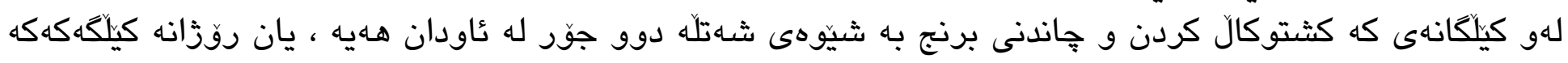

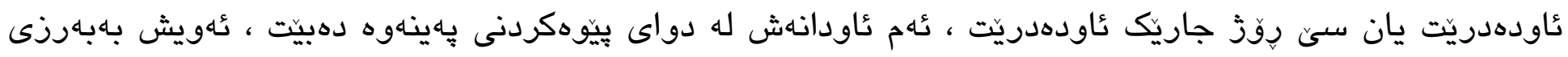

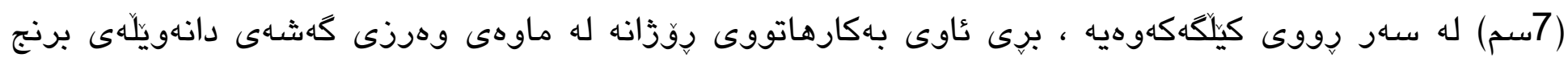

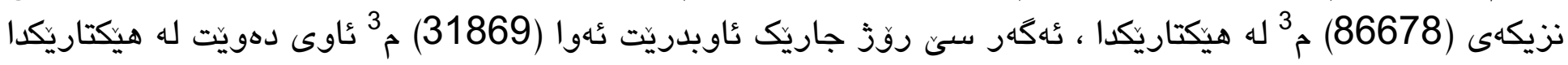

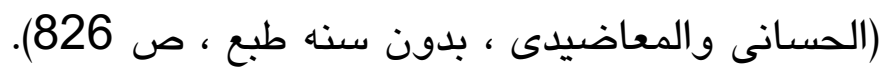




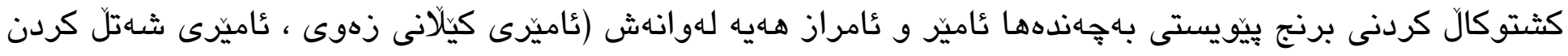

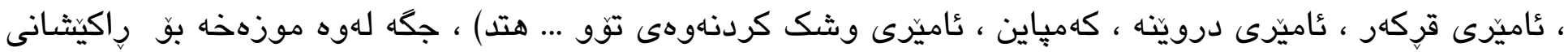

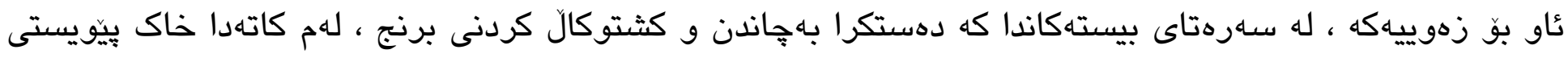

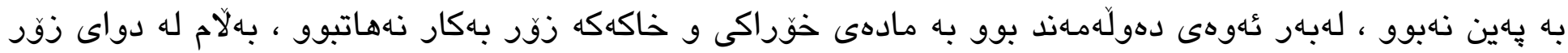

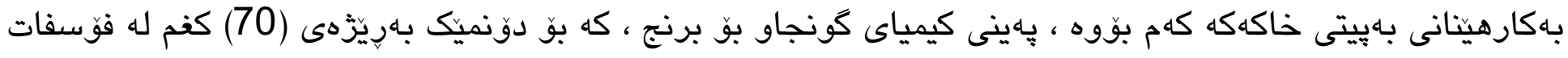

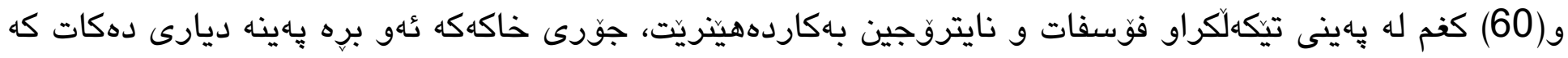

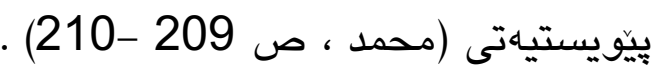

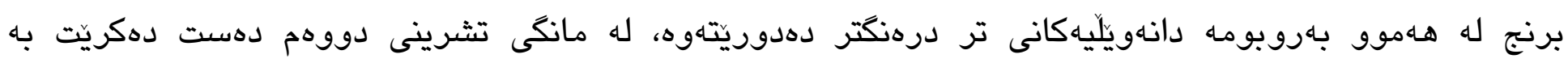

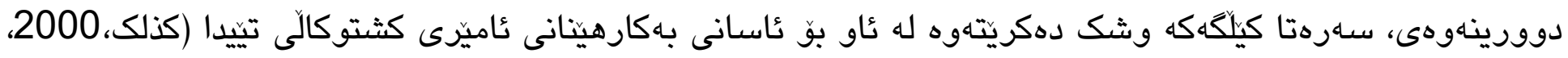
ص234). (234)

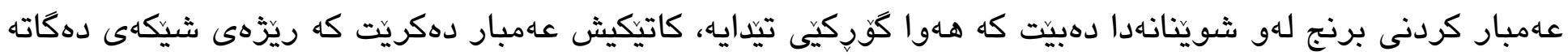

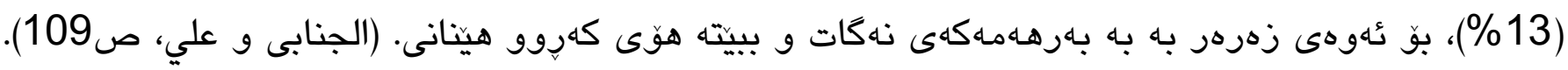

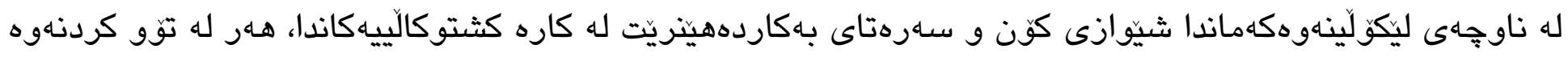

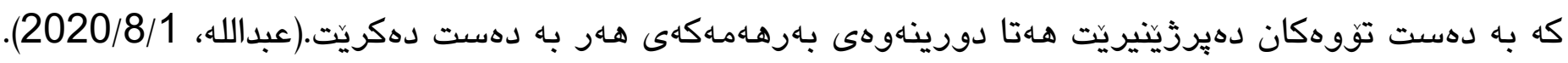

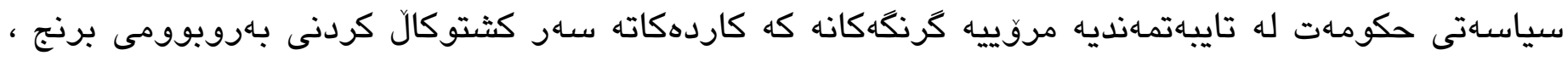

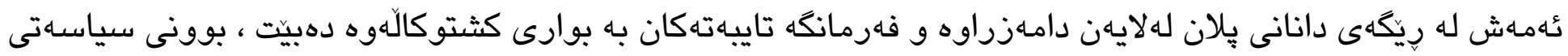

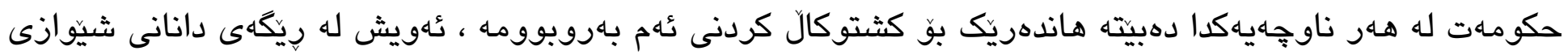

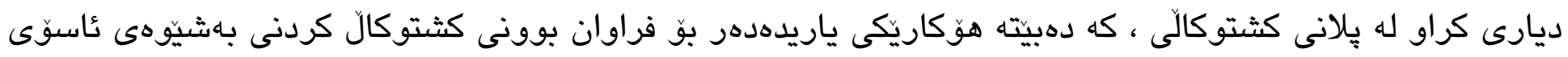

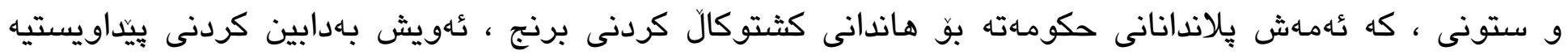

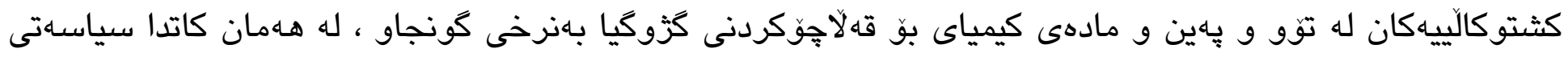

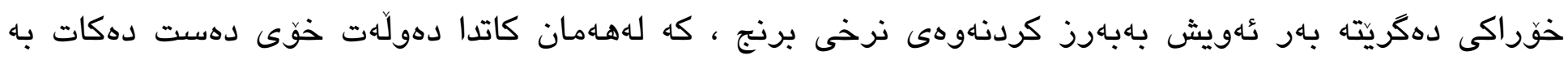

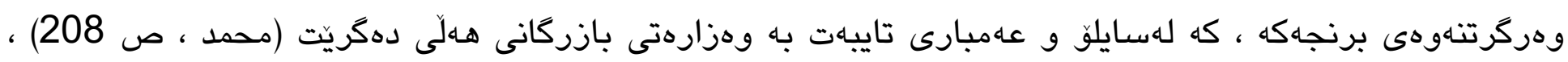

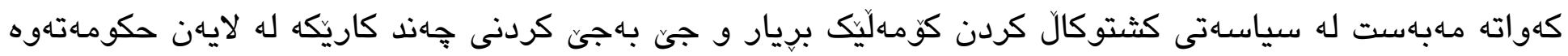

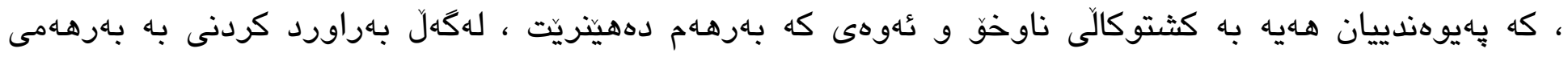

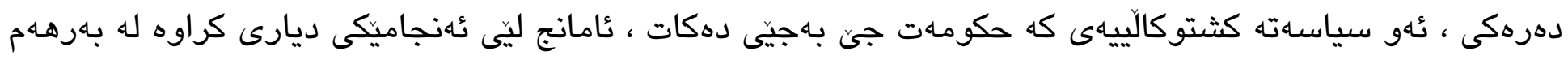

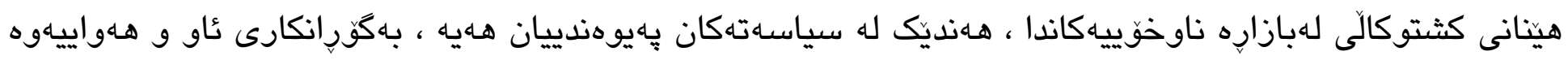

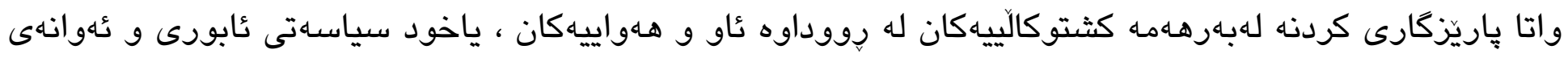

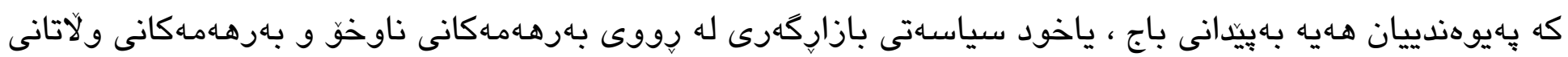

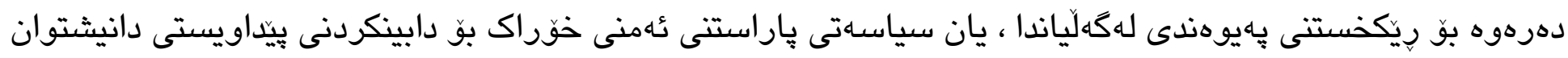

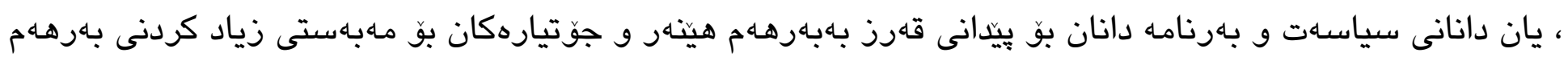

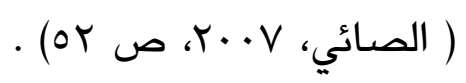




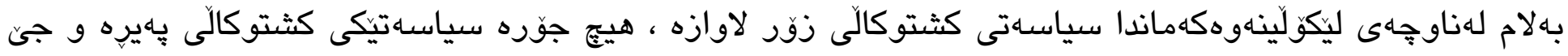

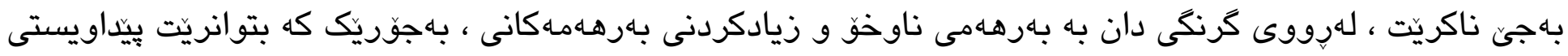

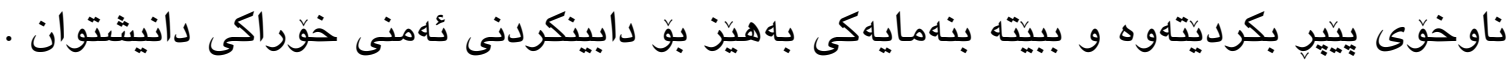

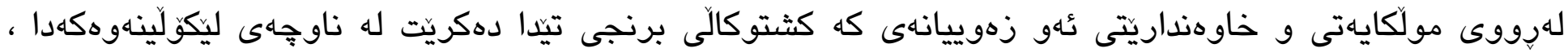

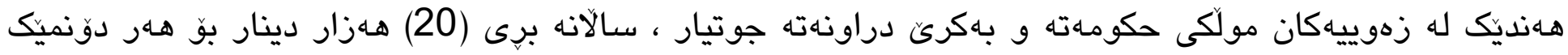

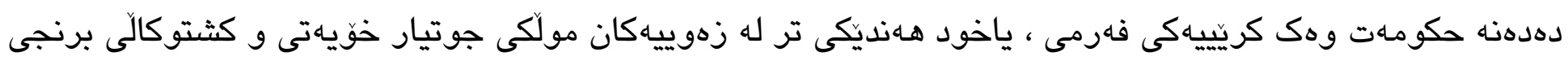

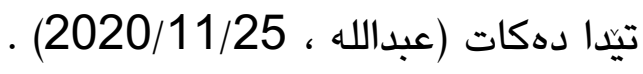

\section{بيّنجوم : كواستثلوه}

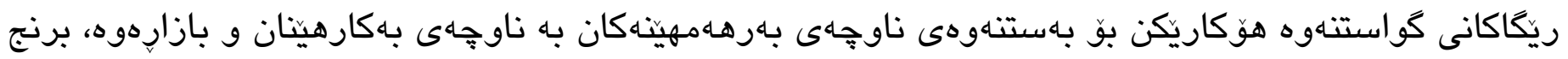

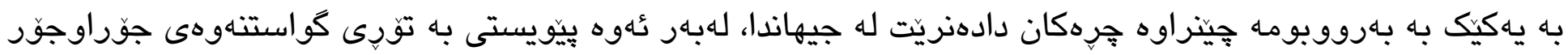

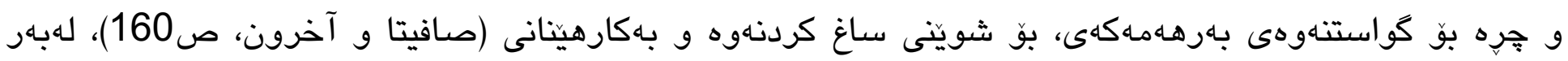

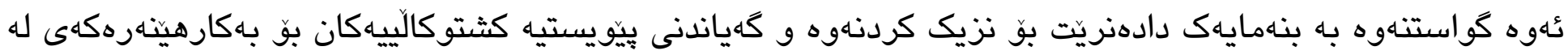

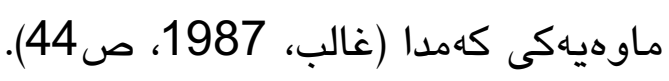

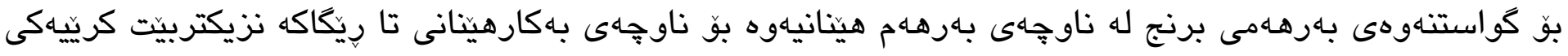

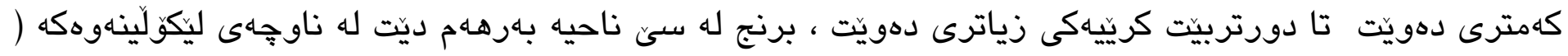

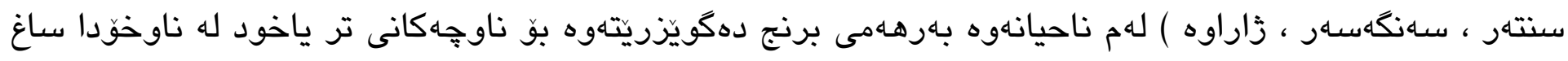
دهريتاهوه .

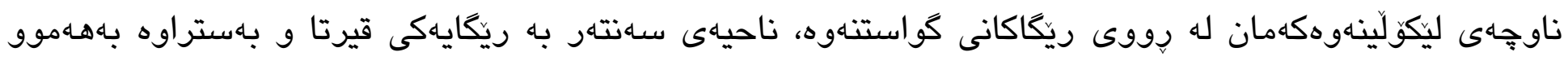

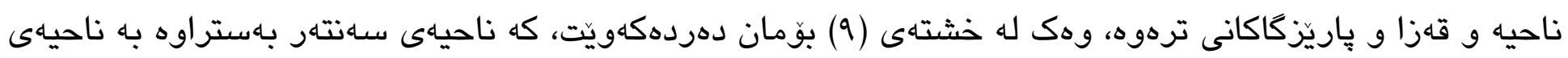

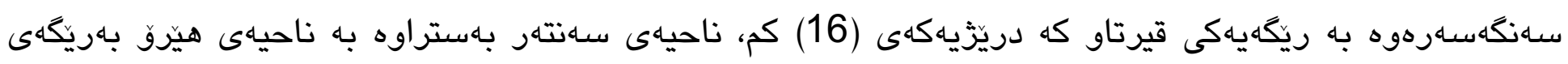

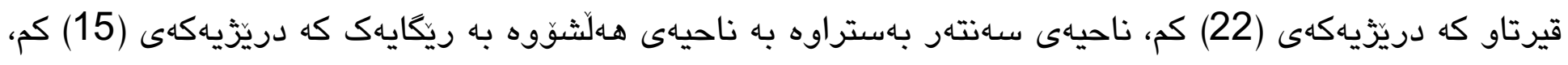

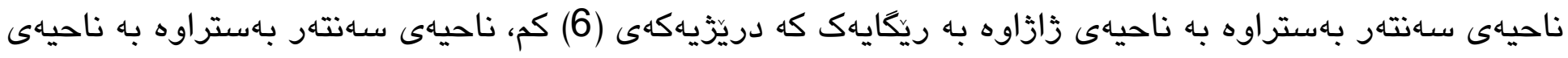

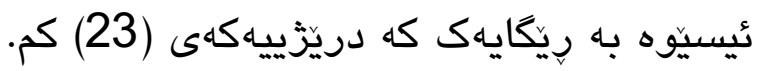

\section{خشتهى (9)}

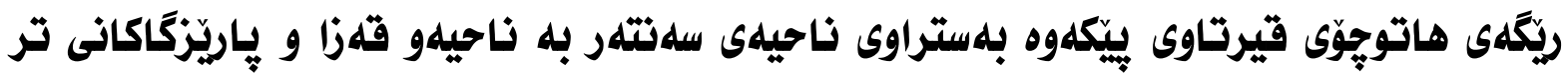




\begin{tabular}{|c|c|c|c|}
\hline دريّزيهـكهى (كم) & ناحيهى سـانتهر(قهلادزيَ)-ناحيهكانى تر & 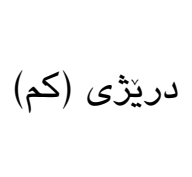 & ناحيهى سهانتهر (قالآدزيَ)- \\
\hline 175 & سهنتهر -سليّمانى & 16 & سهنتهر -سـانكاهـار \\
\hline 146 & سهنتهر-هـهوليّر & 22 & سـنتهر -هيّزوق \\
\hline 26 & سهنتهر -رانيه & 15 & سـانتهر -هـلَلشّو \\
\hline 75 & سهنتهر -كويه & 6 & سهنتهر-زاراوه \\
\hline 28 & سـانتهر -ئيزان & 23 & سانتهار -ئيسيّوكَ \\
\hline
\end{tabular}

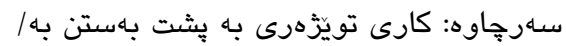

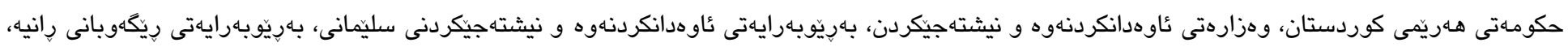
زانيارى بِلاونهكراوه.

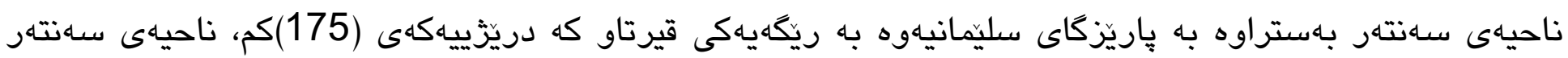

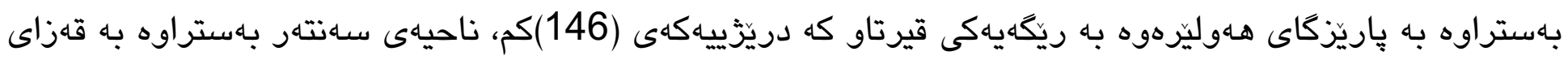

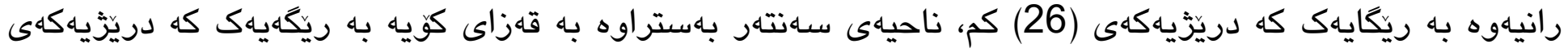

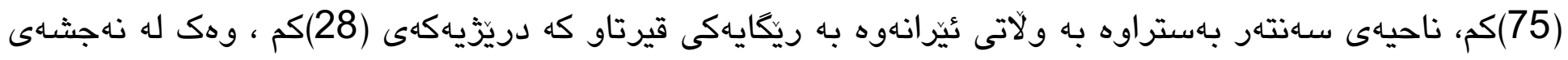

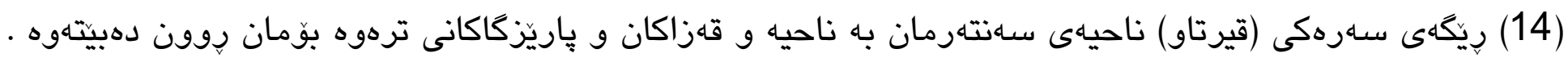

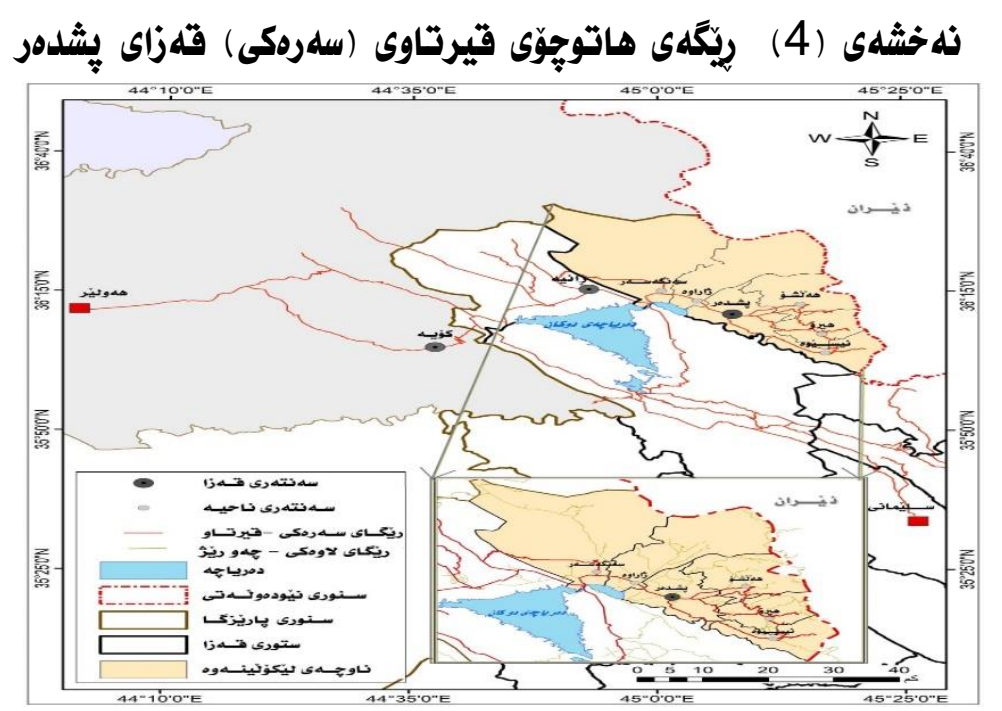

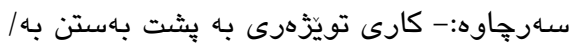

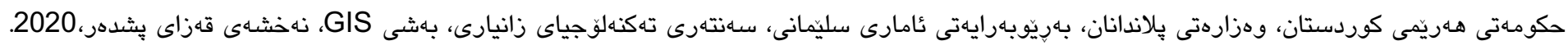

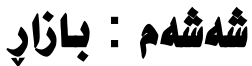

له سـاهدتاى كثتوكال كردنى برنجدا له سالآنى هـشتاكاندا بازار كردن لهسهار خواستى كريار و فروشيار

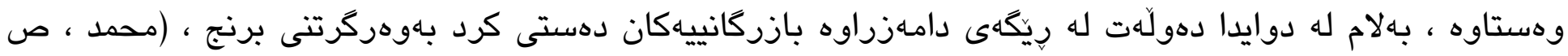

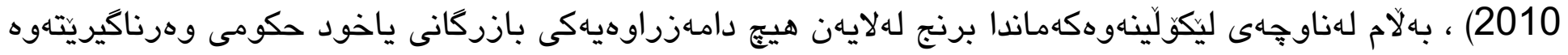




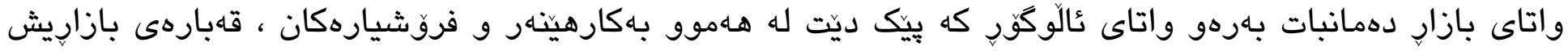

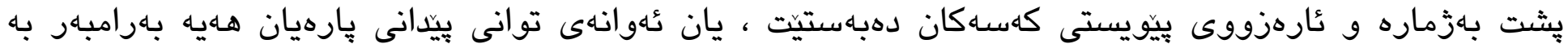

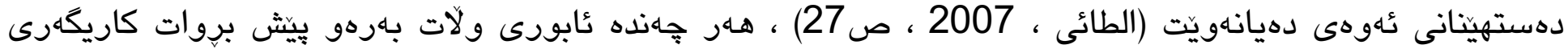

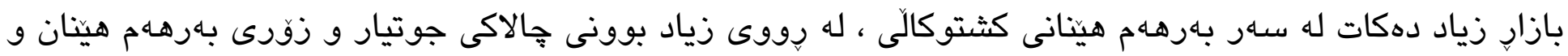

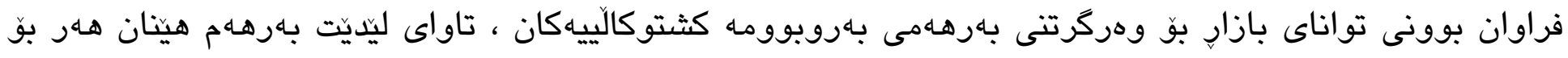

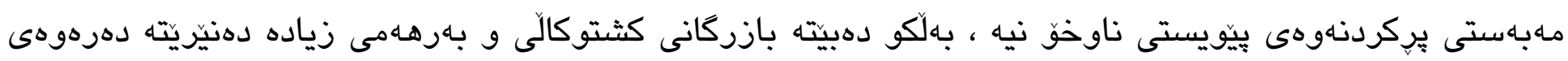

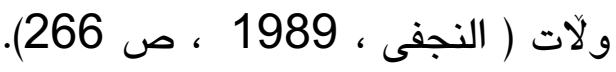

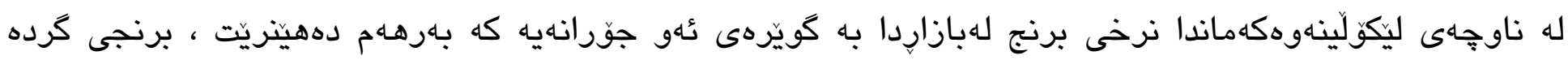

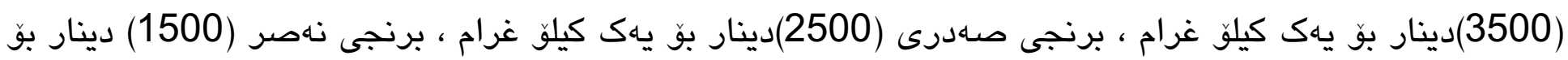

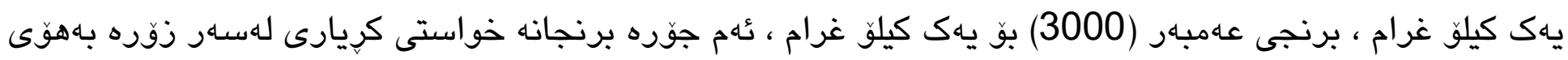

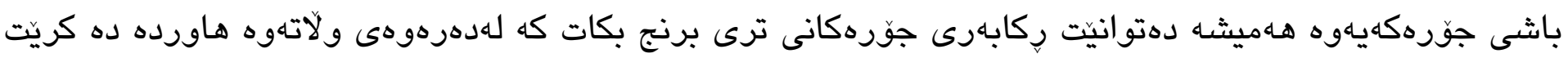

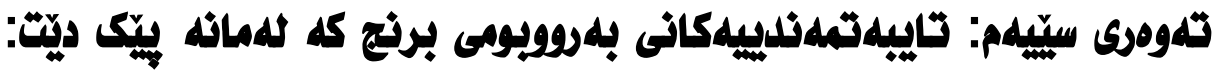

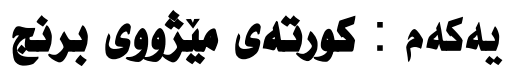

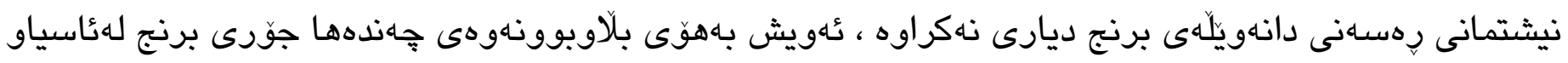

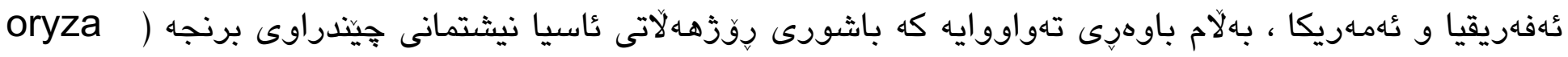

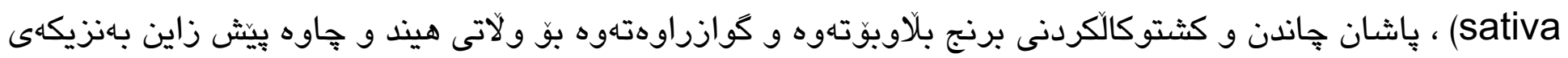

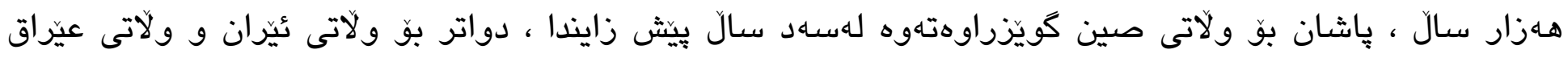

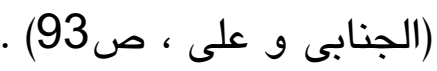

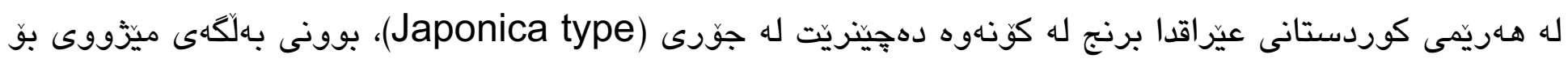

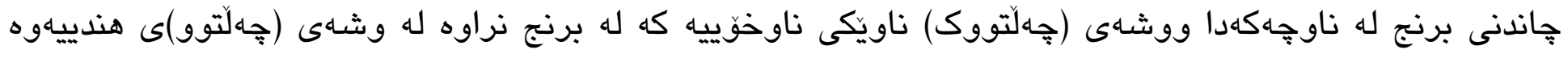

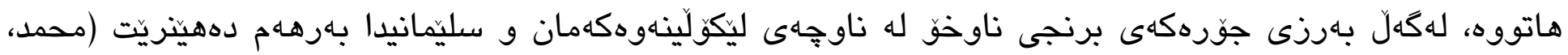

\section{دووم : كرنكى برنج لله نُابووريلا}

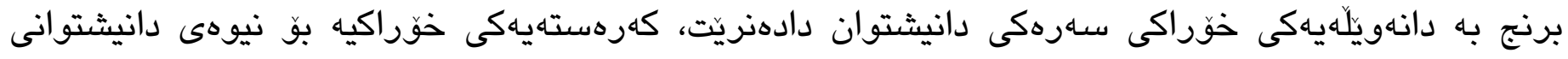

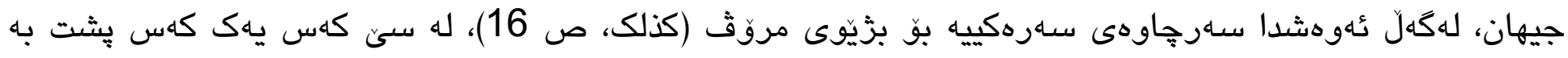

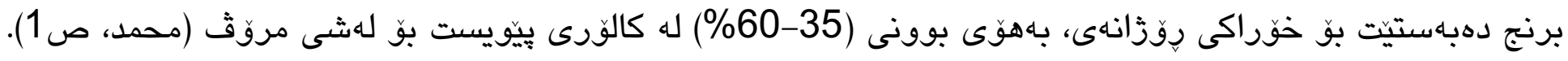

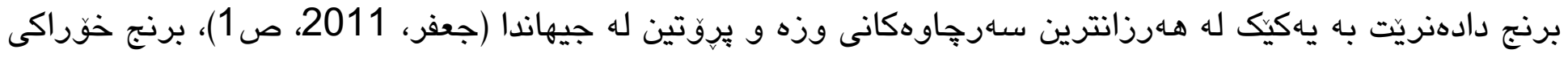

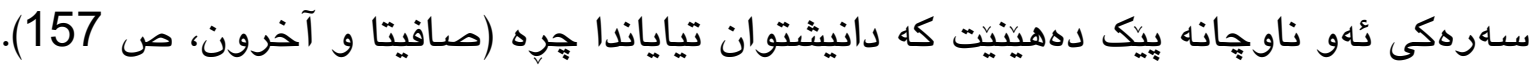

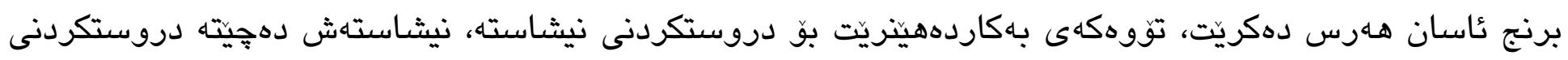

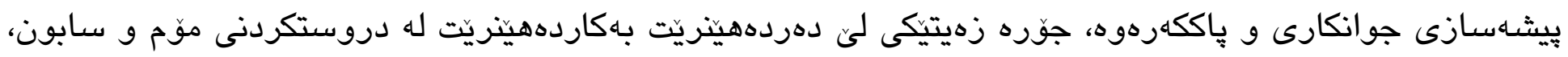

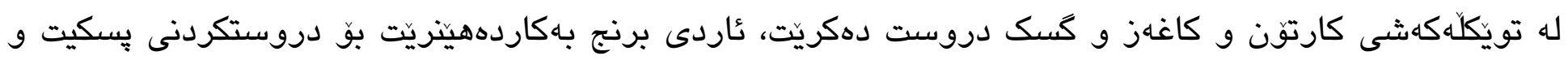

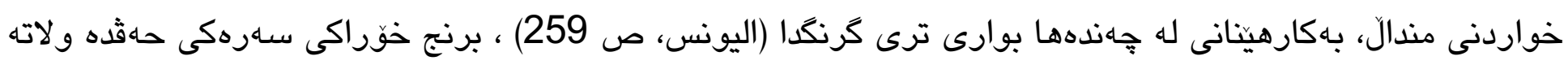




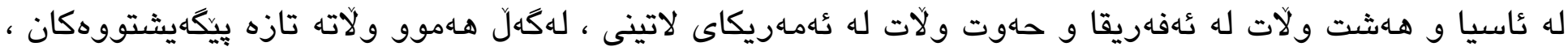

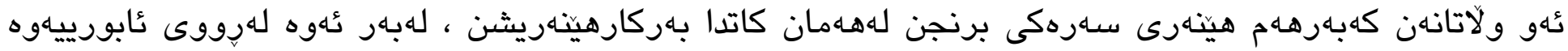

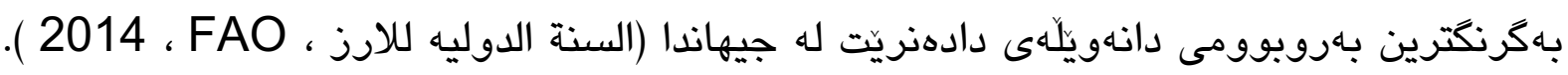

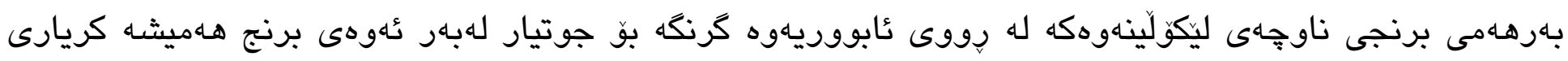

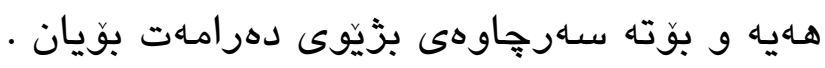

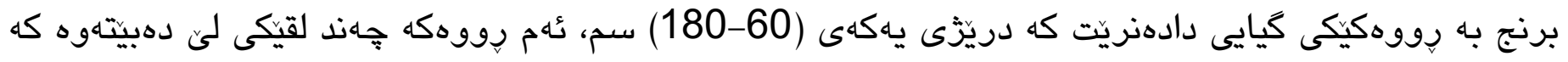

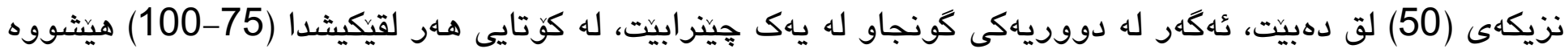

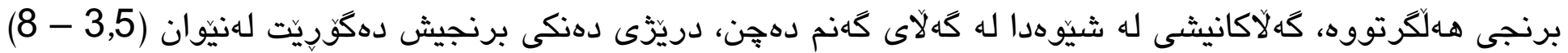

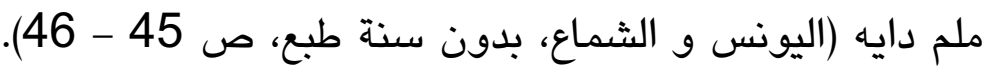

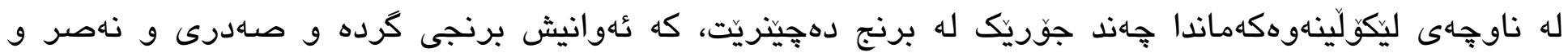

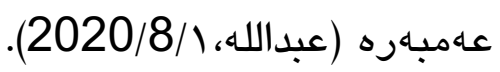

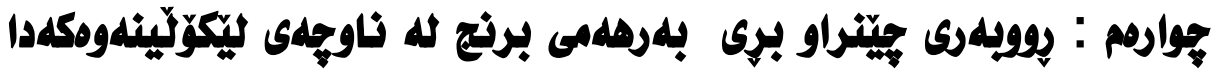

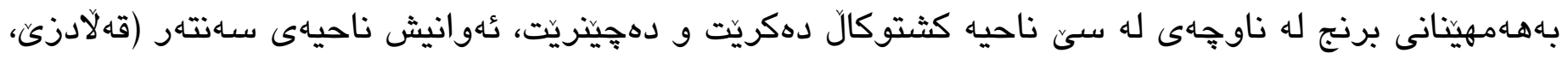

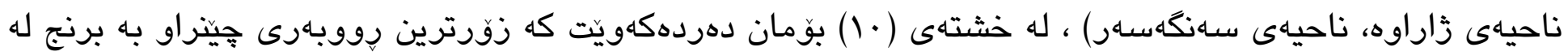

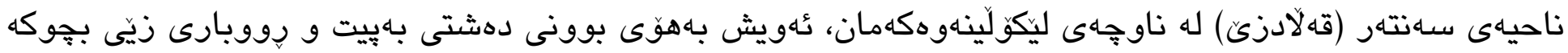

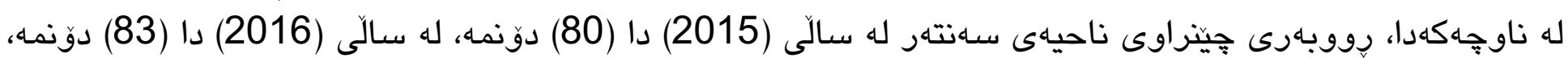

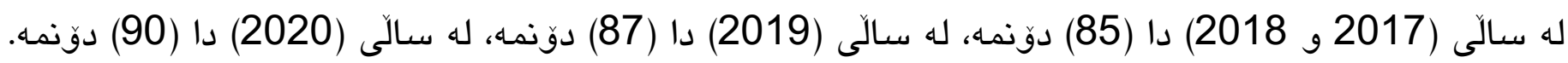

\section{خشتهى (1.)}

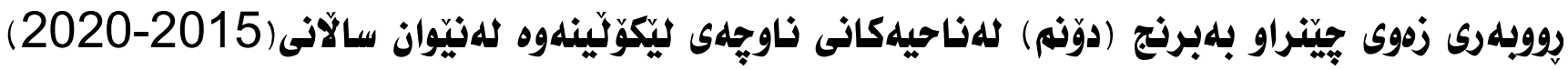

\begin{tabular}{|c|c|c|c|c|c|c|}
\hline 2020 & 2019 & 2018 & 2017 & 2016 & 2015 & ناحيهكان \\
\hline 90 & 87 & 85 & 85 & 83 & 80 & سهنتهر (قهلادزيَ) \\
\hline 30 & 22 & 21 & 21 & 21 & 20 & ز زاراوه \\
\hline 25 & 18 & 12 & 12 & 12 & 15 & سهنكهسهر \\
\hline 1 \&o & ITV & 111 & 111 & 117 & 110 & كوى كثتى \\
\hline
\end{tabular}

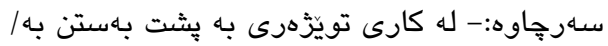

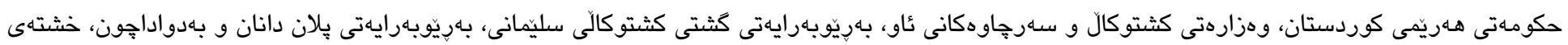

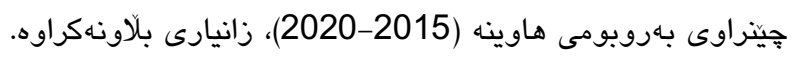

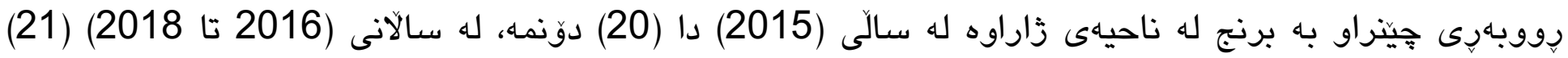

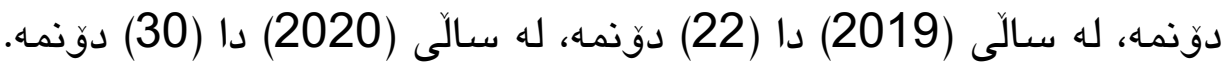

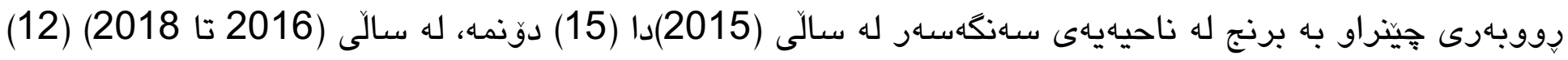

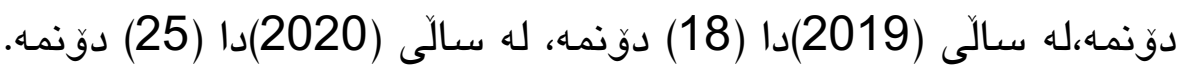




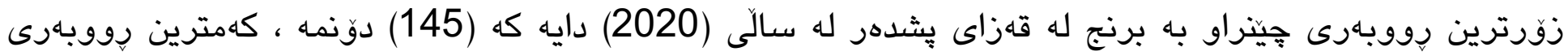

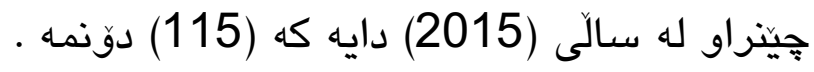

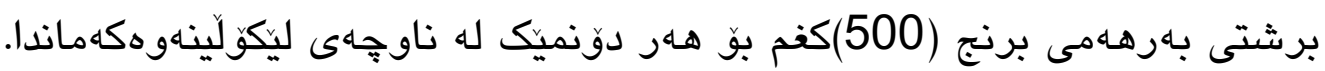

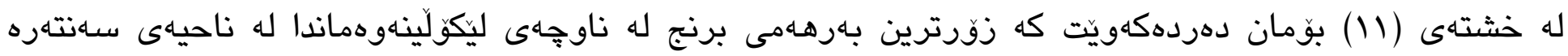

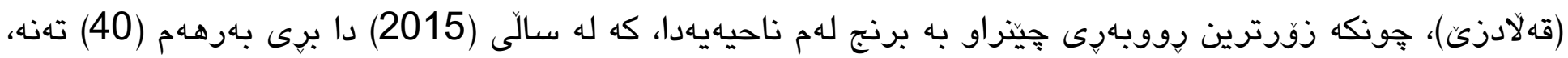

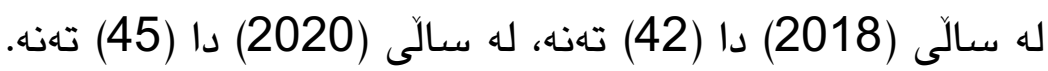

خشتهى (II)

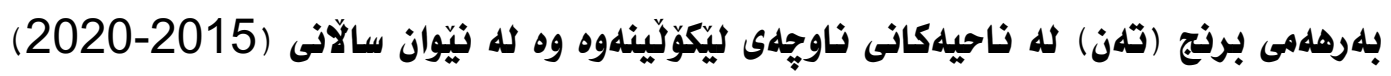

\begin{tabular}{|c|c|c|c|c|c|c|}
\hline 2020 & 2019 & 2018 & 2017 & 2016 & 2015 & ناحيهكان \\
\hline 45 & 43 & 42 & 42 & $4 r$ & 40 & سهانتهر (قهلادزيَ) \\
\hline 15 & 11 & 10 & 10 & 10 & 10 & ثراراوه \\
\hline 12 & 9 & 6 & 6 & 6 & 7 & سهنكاهسهر \\
\hline$V Y$ & 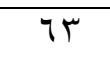 & 01 & 01 & 01 & 57 & كوى كشتى \\
\hline
\end{tabular}

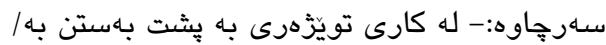

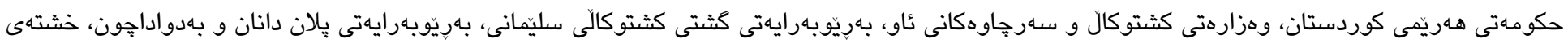
جيخزاوى بهروبومى هاوينه (2015-2020)، زانيارى بالاونهكراوه.

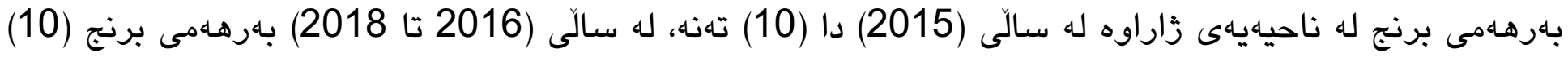

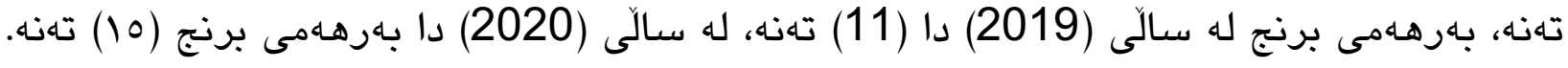

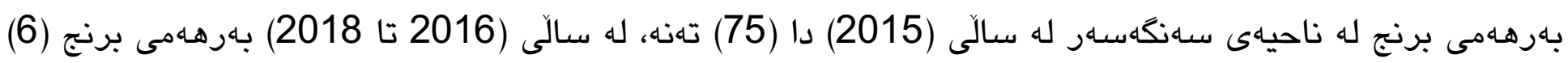

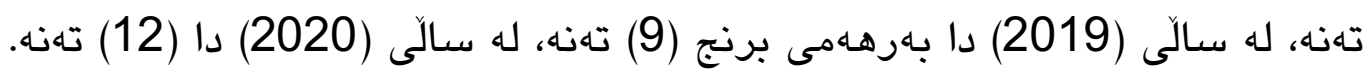

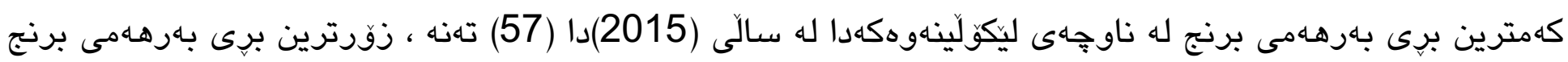
له سالى (2020) دايه (72) تهنه.

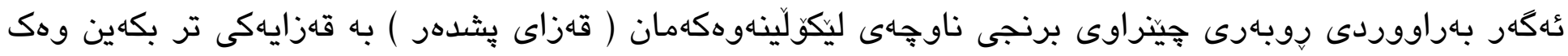

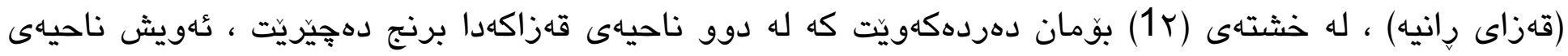
جوارقورنه و ناحياهى سهرووجاوهيه.

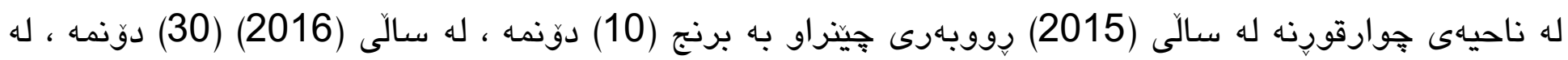

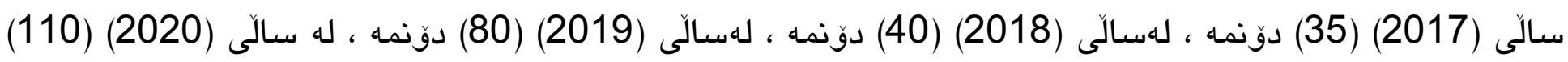
دوّنمه .

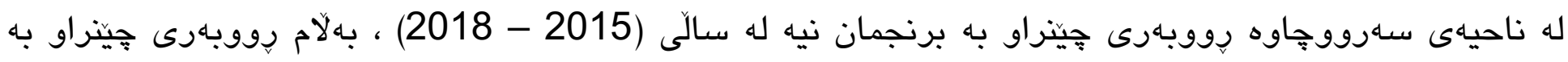

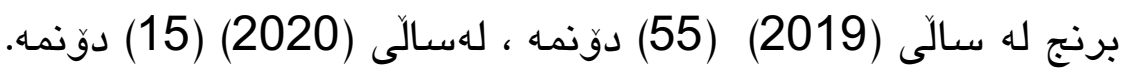

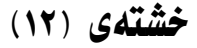




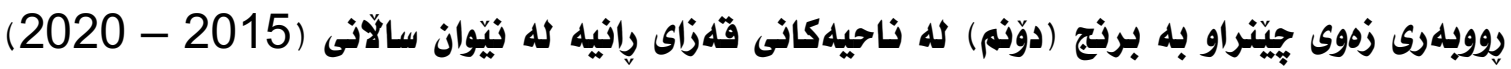

\begin{tabular}{|c|c|c|c|c|c|c|}
\hline 2020 & 2019 & 2018 & 2017 & 2016 & 2015 & ناحيهكان \\
\hline 110 & 80 & 40 & 35 & 30 & 10 & جوارقورنه \\
\hline 15 & 55 & - & - & - & - & سـهرووجاوه \\
\hline Iro & 1 1ro & $\varepsilon$. & ro & r. & 1. & كوى كثتتى \\
\hline
\end{tabular}

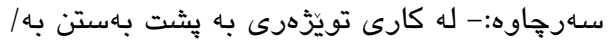

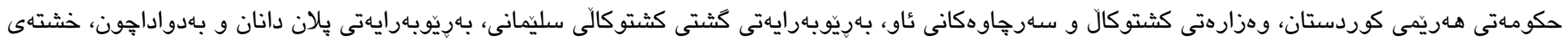

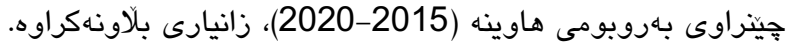

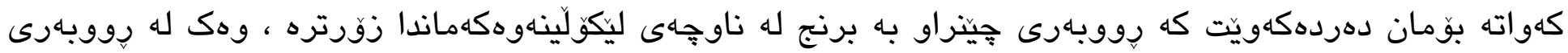

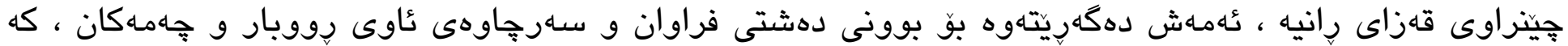

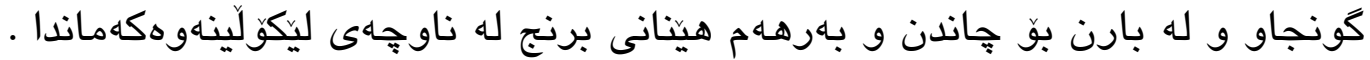

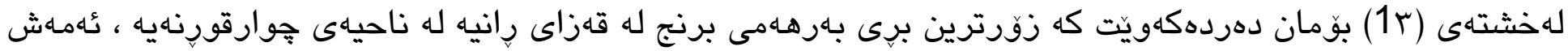

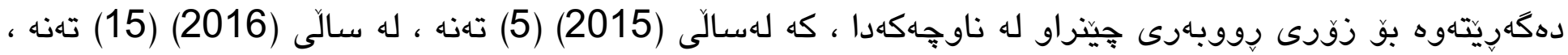

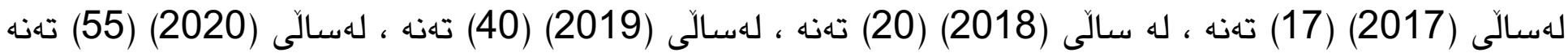

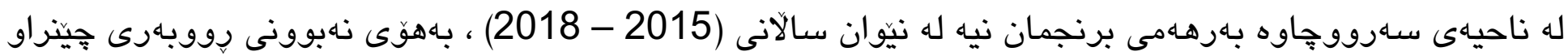

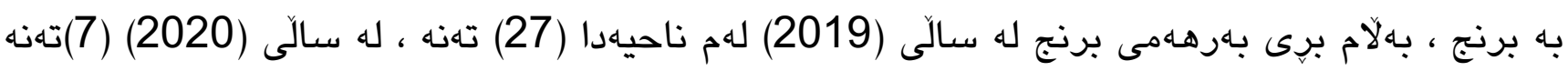
خشتهى (IT)

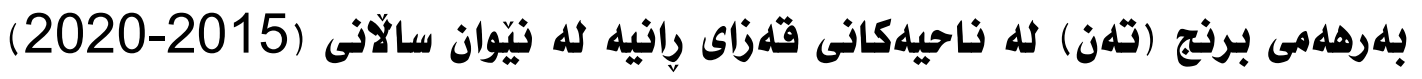

\begin{tabular}{|c|c|c|c|c|c|c|}
\hline 2020 & 2019 & 2018 & 2017 & 2016 & 2015 & ناحيهكان \\
\hline 55 & 40 & 20 & 17 & 15 & 5 & جوارقورنه \\
\hline 7 & 27 & - & - & - & - & سـهرووجاوه \\
\hline$T Y$ & $7 V$ & r. & IV & 10 & 0 & كوى كُثت \\
\hline
\end{tabular}

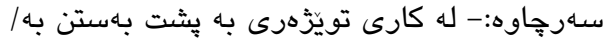

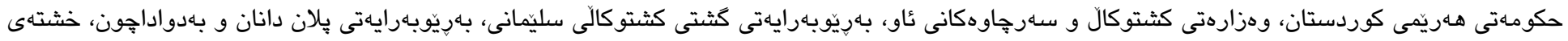

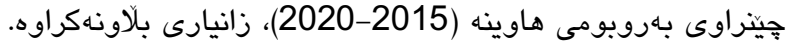

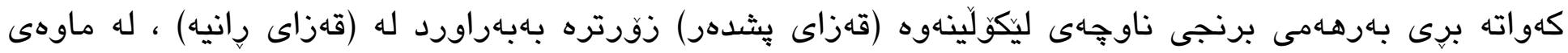

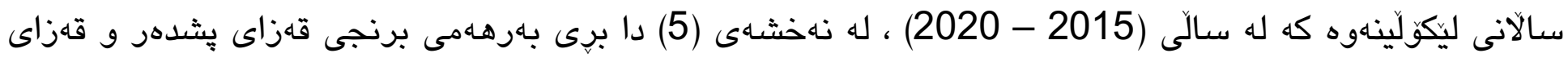
رانيهمان بو دهردهكهويت . 
نه نه نه (5)

\section{بهرهلمى برنجى قهزاى يشدهر و قهزاى رِانيه له نيّوان سالآنى (5 (2015 - 2020)}

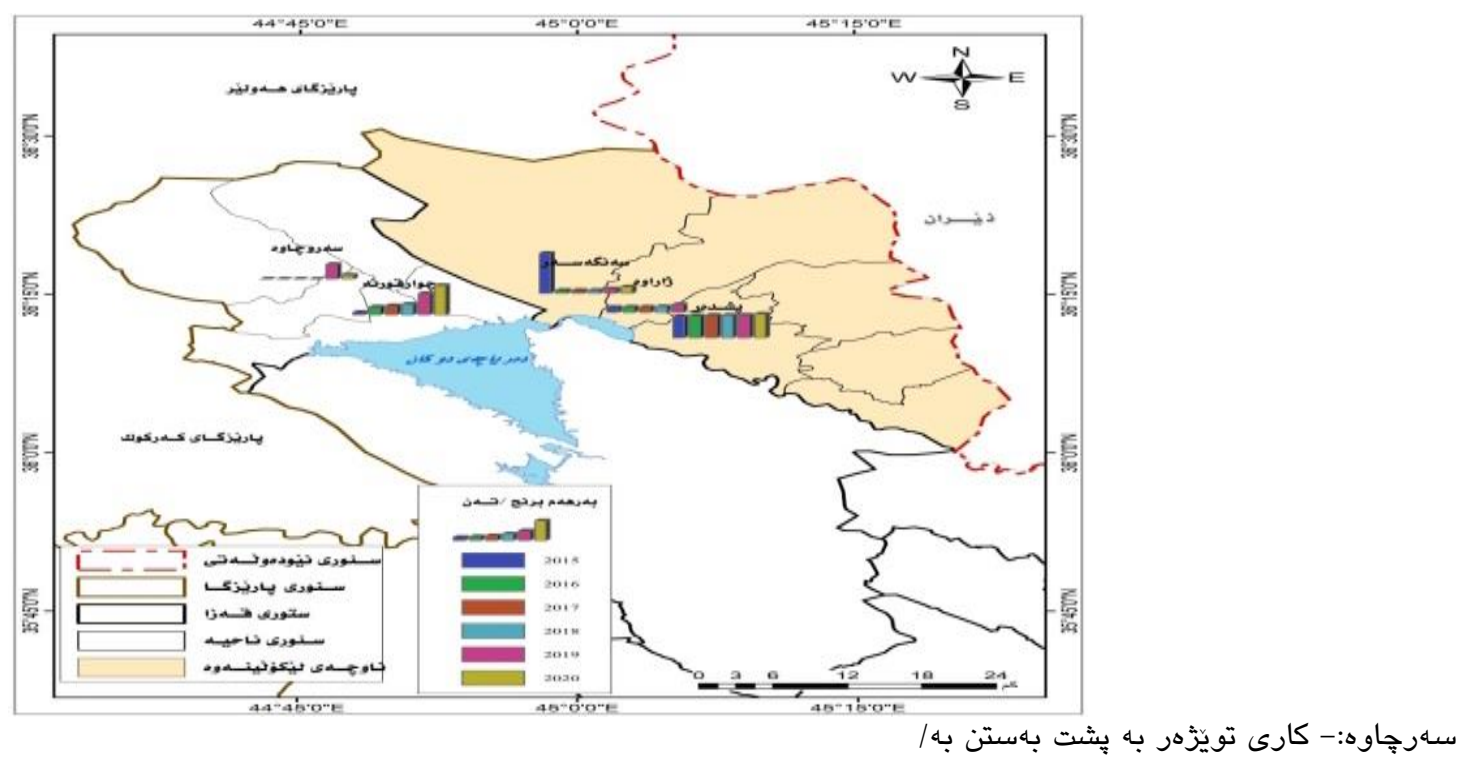

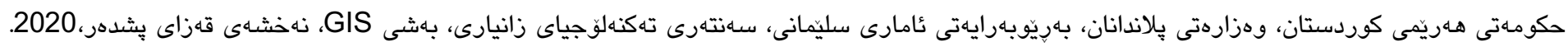

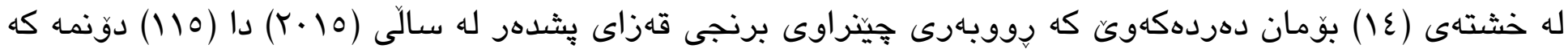

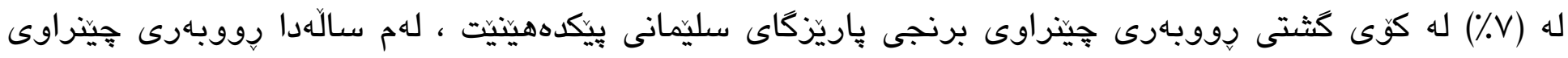

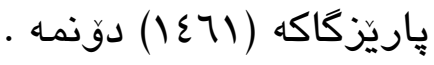

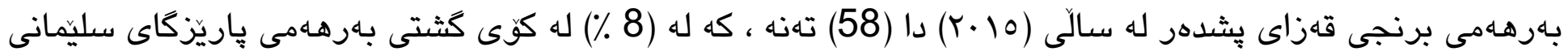

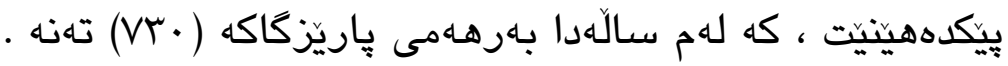

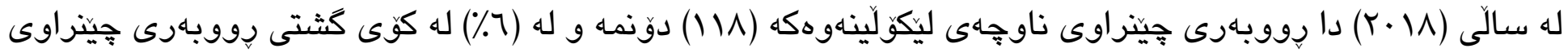

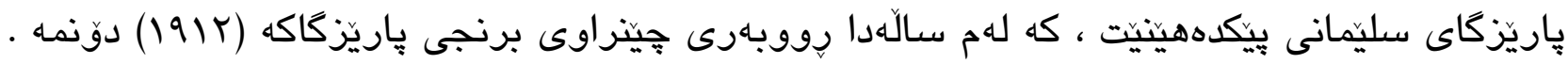

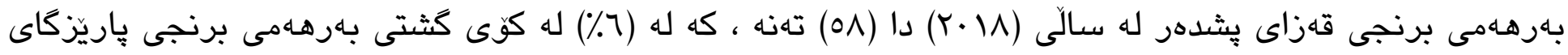

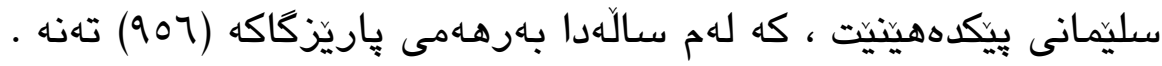

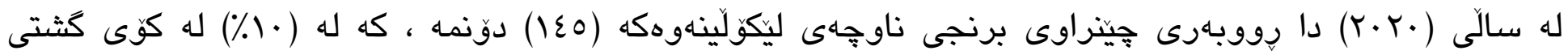

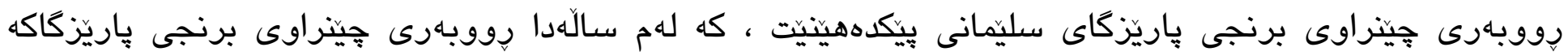

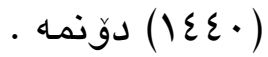

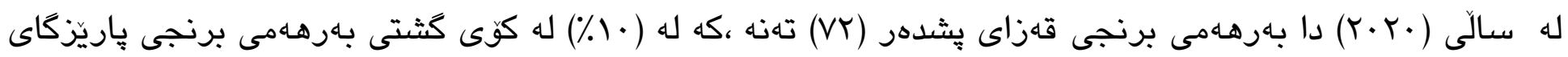

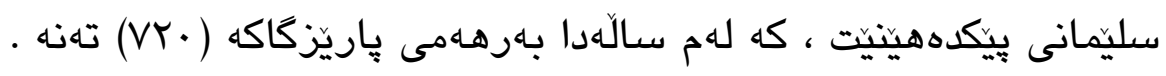




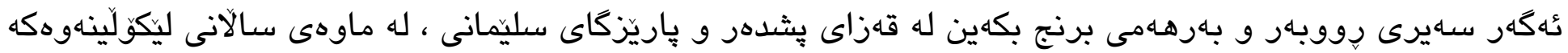

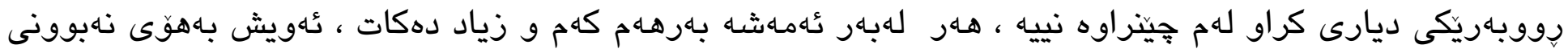

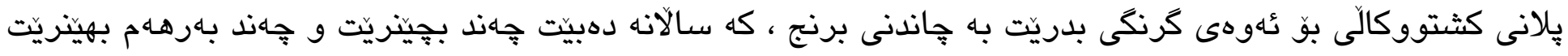

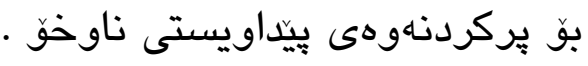

\section{خشتهى (1乏)}

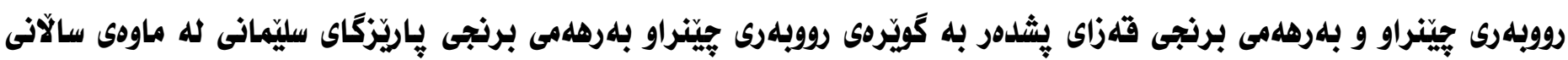
(2020-2015)

\begin{tabular}{|c|c|c|c|c|c|c|}
\hline 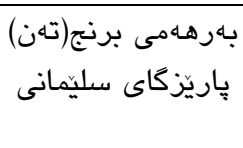 & 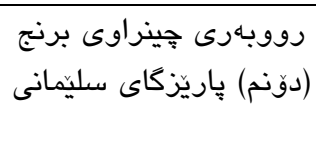 & سيّزهى & بهرهـمى برنج(تهن) قهزاى & سيَّنهى & رووبهرى (پِينراوى برنج & سـال \\
\hline$V^{\mu}$. & $|\varepsilon 7|$ & $\% \wedge$ & $0 \wedge$ & $\%$ & 110 & $r .10$ \\
\hline 人०乏 & $18 \cdot 9$ & $\%$ & $0 \wedge$ & $\%$ & 117 & $r .17$ \\
\hline Aro & 1701 & $\% \mathrm{~V}$ & $0 \wedge$ & $\% \mathrm{~V}$ & 111 & $r . I V$ \\
\hline 907 & 1915 & $\% 7$ & $0 \wedge$ & $\% 7$ & 111 & $r \cdot M$ \\
\hline $1.0 \mathrm{~V}$ & YIIO & $\% 7$ & rד & $\% 7$ & ITV & $r .19$ \\
\hline VT. & $\mid \varepsilon \varepsilon$. & $\%$ & VT & $\%$ & $1 \varepsilon 0$ & $r \cdot r$. \\
\hline
\end{tabular}

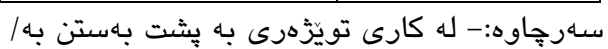

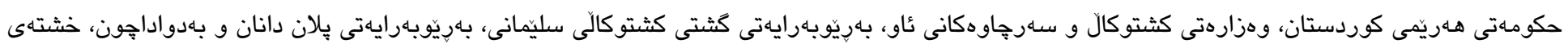

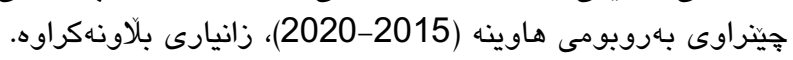

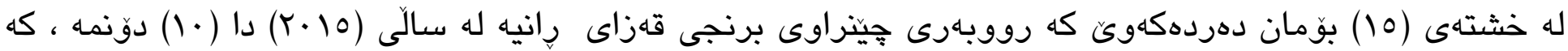

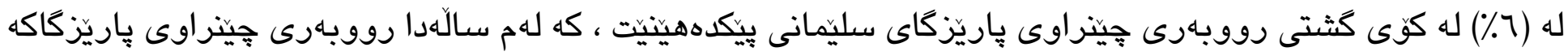
.

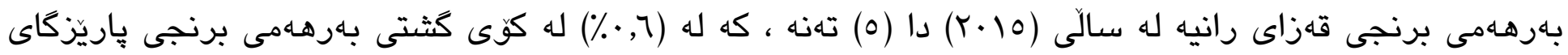

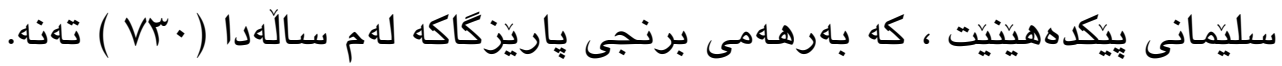

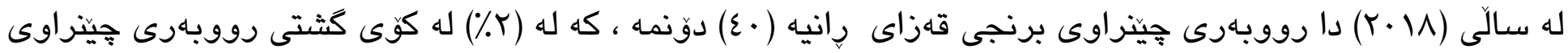

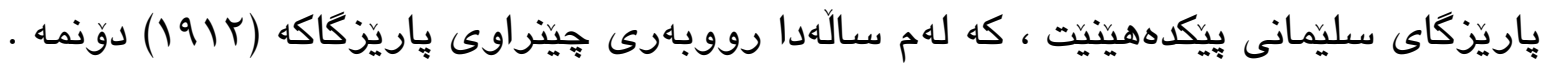

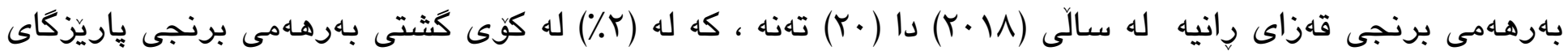

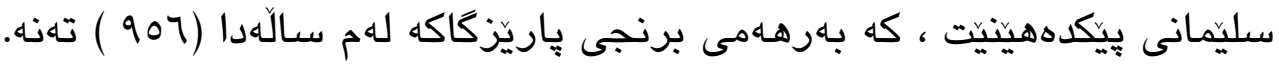




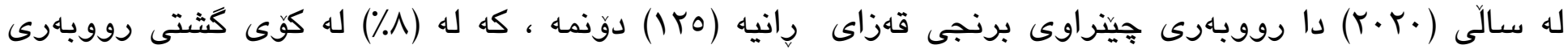

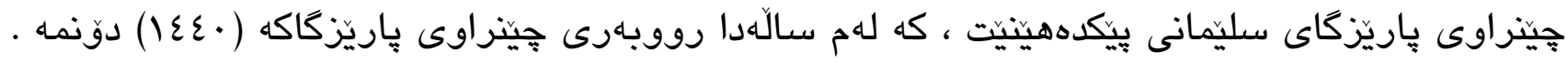

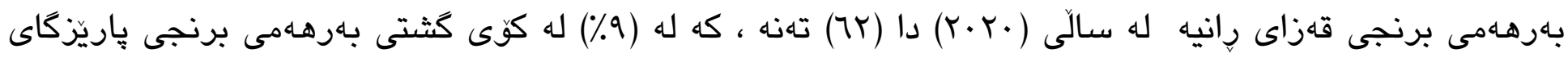

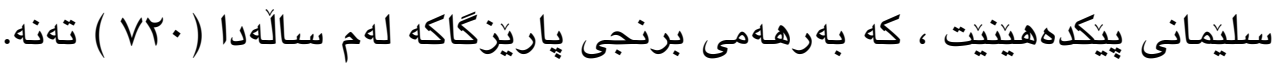

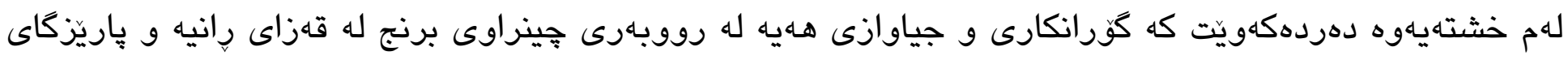

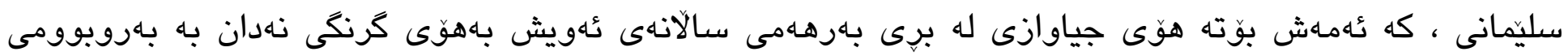

خشتمه (10)

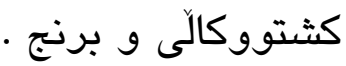

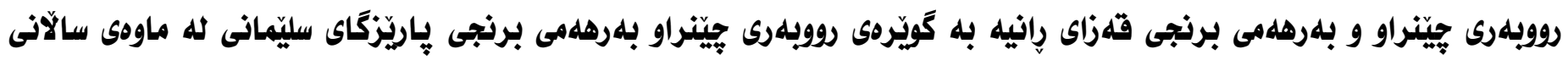
(2020-2015)

\begin{tabular}{|c|c|c|c|c|c|c|}
\hline 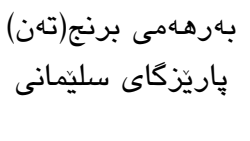 & 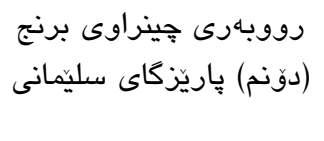 & ريّزهى & بهرهـهى برنج(تهن) قهزاى & سيزّهى & 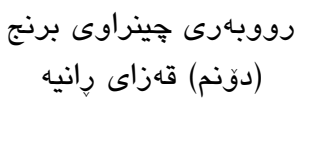 & سـال \\
\hline$v_{\mu}^{\mu}$. & $|\varepsilon 7|$ & $\% \cdot, 7$ & 0 & $\% \cdot, 7$ & 1. & $r \cdot 10$ \\
\hline$\Lambda 0 \varepsilon$ & $1 V \cdot 9$ & $\% r$ & 10 & $\% r$ & $r$. & $r .17$ \\
\hline NTO & 1701 & $\% r$ & IV & $\% r$ & ro & $r \cdot I V$ \\
\hline 907 & 1915 & $\% r$ & $r$. & $\% r$ & $\varepsilon$. & $r \cdot M$ \\
\hline $1.0 \mathrm{~V}$ & KIIO & $\% 7$ & $7 V$ & $\% 7$ & o & $r \cdot 19$ \\
\hline VT. & $\mid \varepsilon \varepsilon$. & $\% 9$ & $7 r$ & $\% \wedge$ & ITO & $r \cdot r$. \\
\hline
\end{tabular}

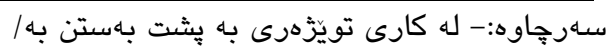

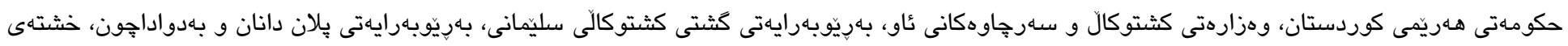

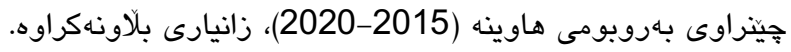

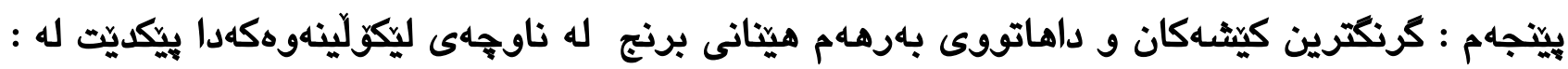

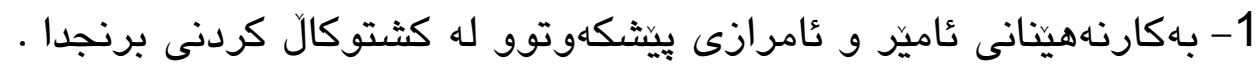

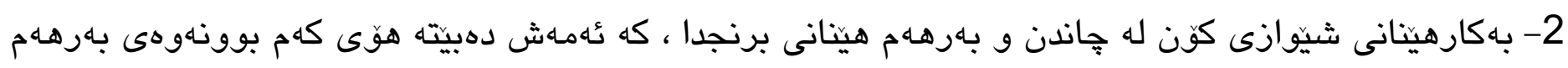

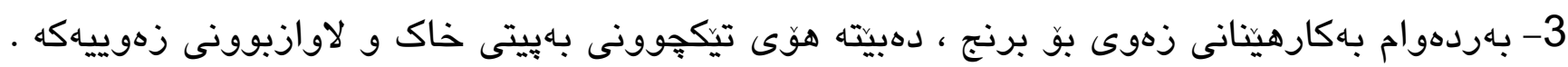

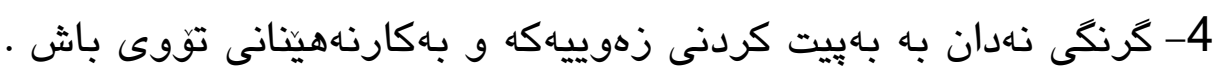

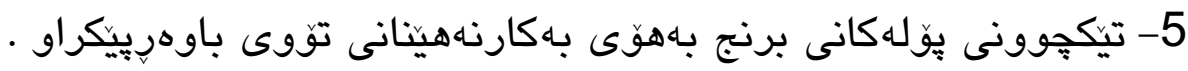

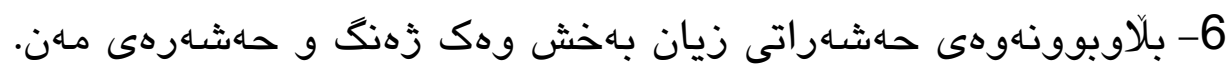

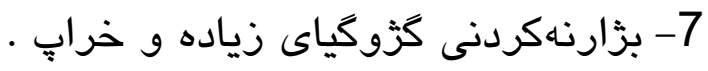

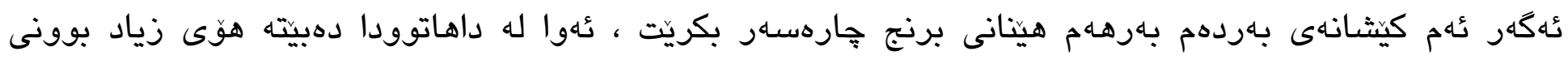

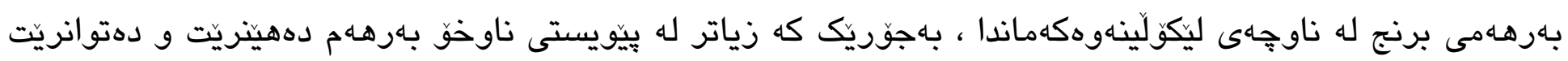


بنيّريته دهرهوه و ركابهرى برنجهكانى ترى بيّيكريّت ، جونكه لهوروىى جوّرهوه بهاباشترين جوّرى برنج دادهنريّت ، كه

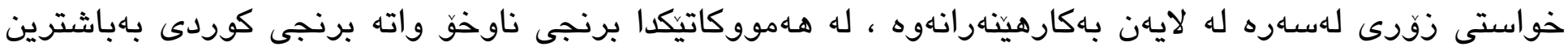
جوّرى برنج دادهنريّت .

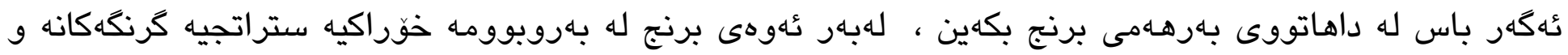

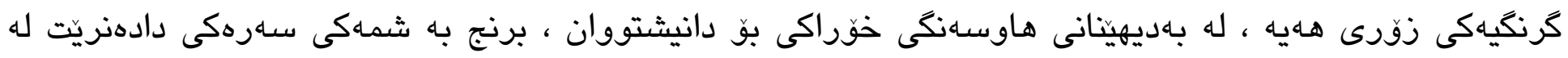

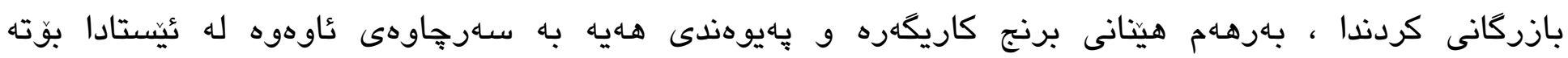

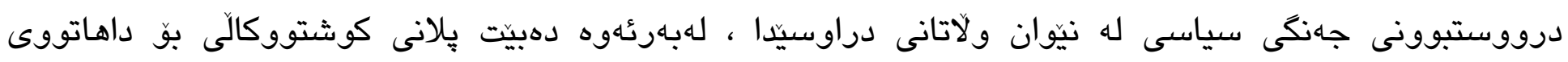

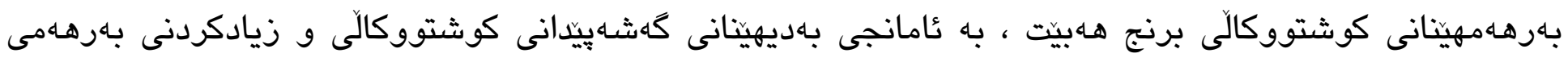

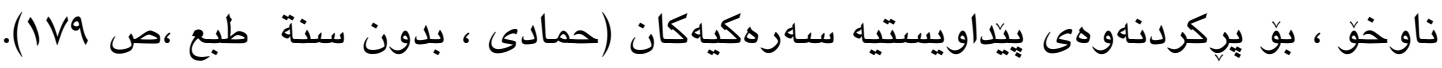

\section{ثلهنجام}

كئنجامى تويَّزينهودكه كَيشت بهم خالآنهى لاى خوارهوه:

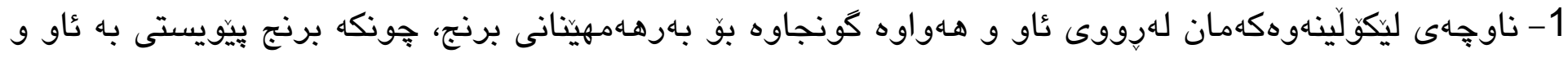

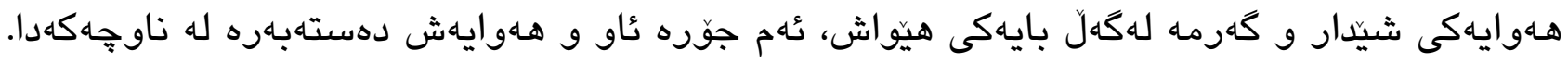

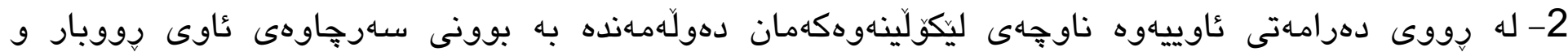

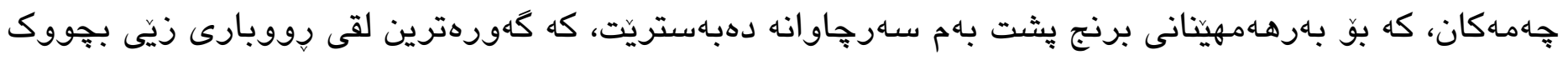

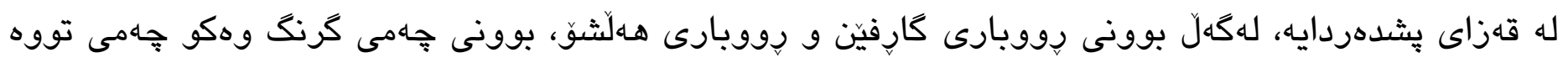

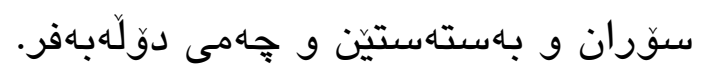

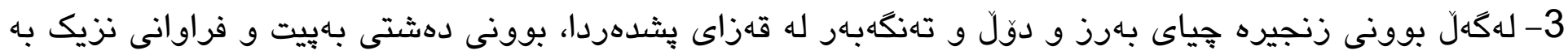

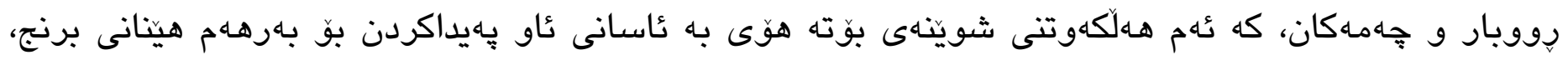

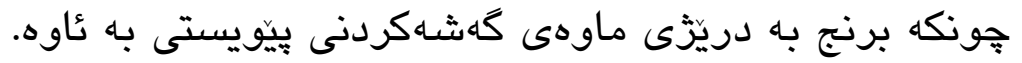

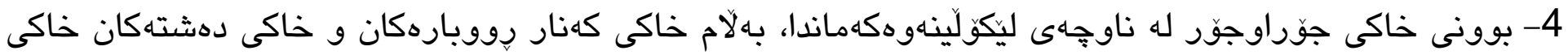

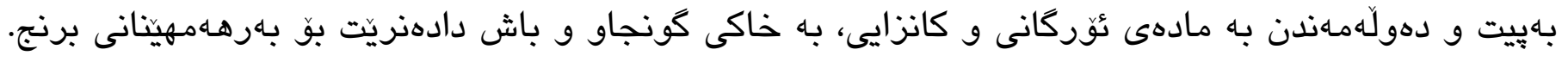

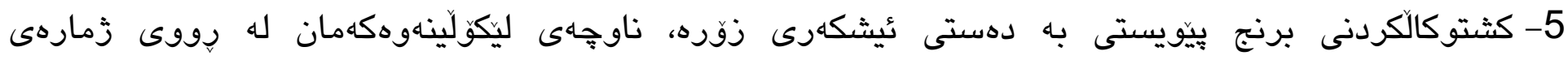

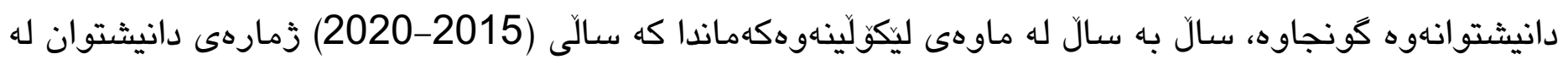

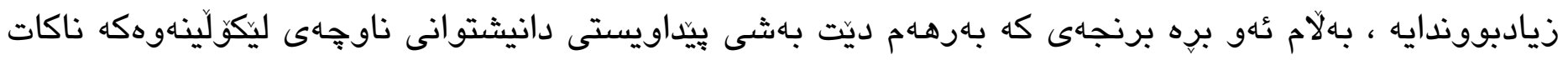

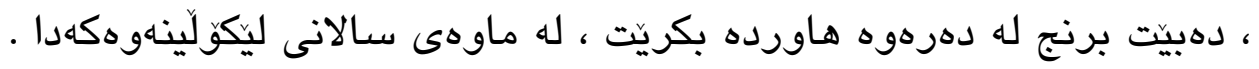




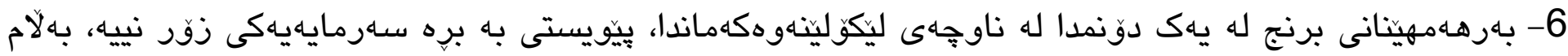

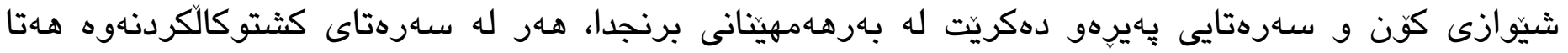

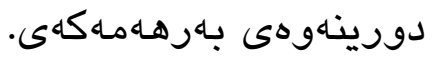

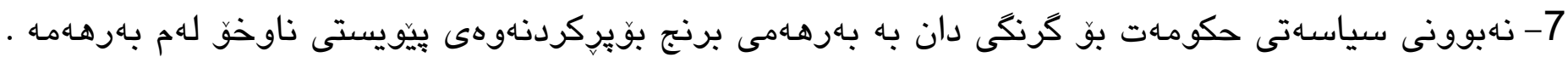

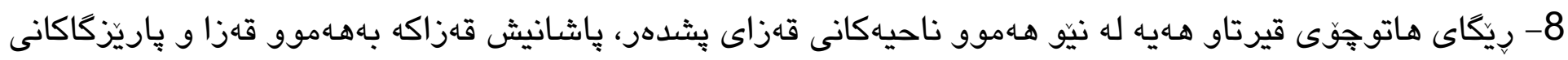

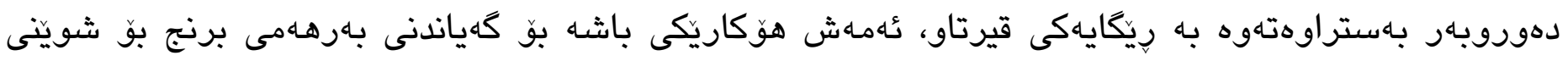
بـكارهينانى.

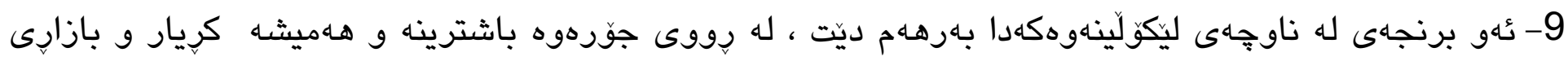

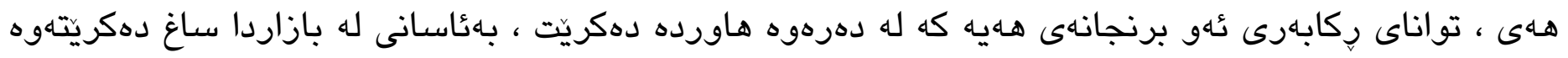

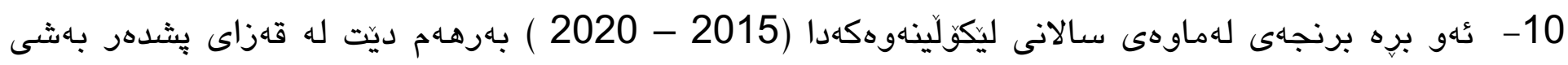

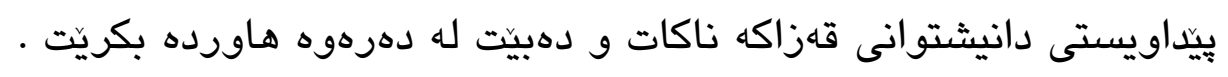

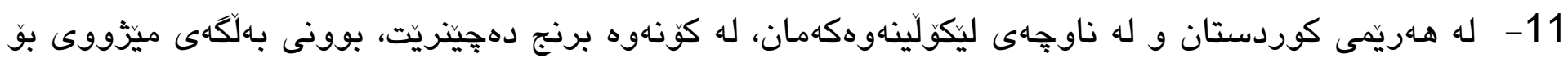

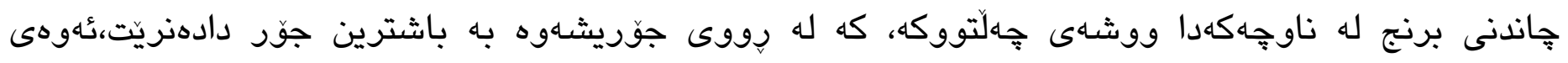

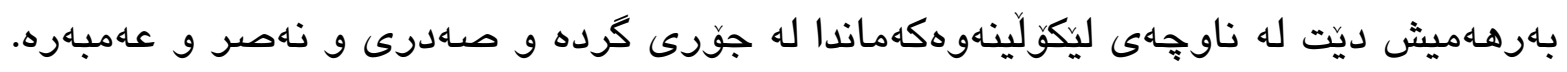

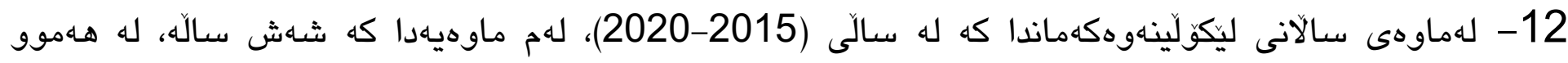

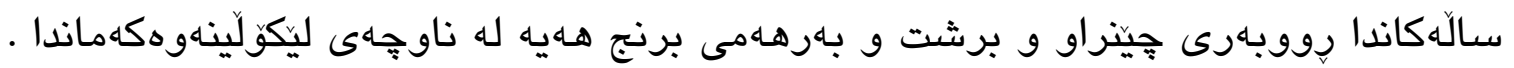

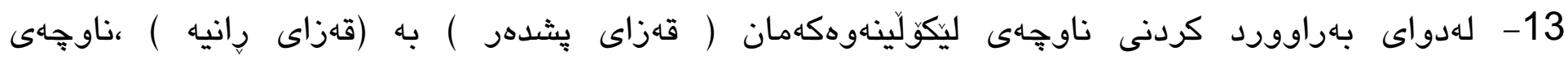

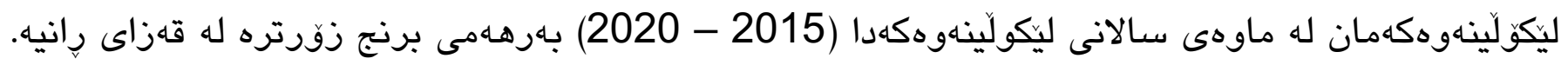




\section{وإسياردمكان}

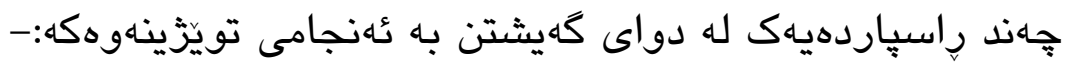

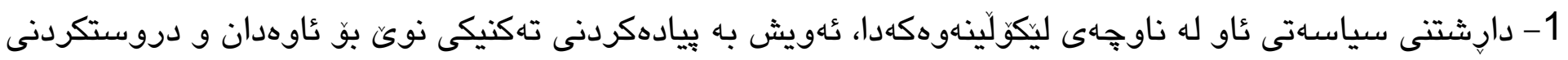

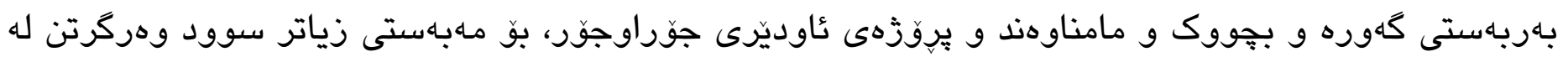

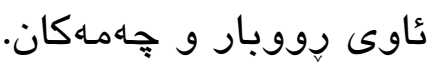

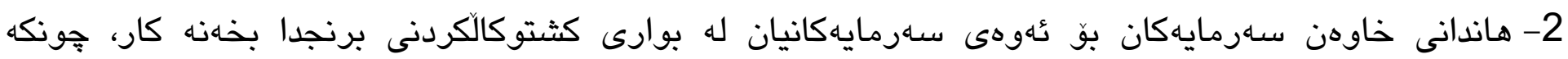

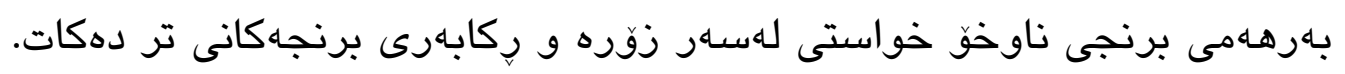

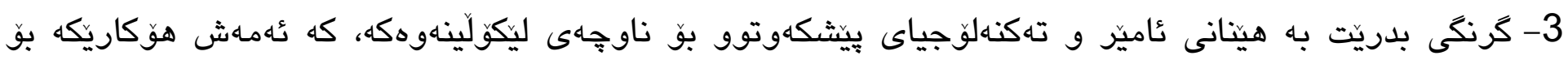

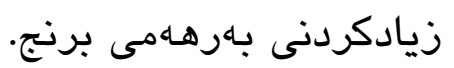

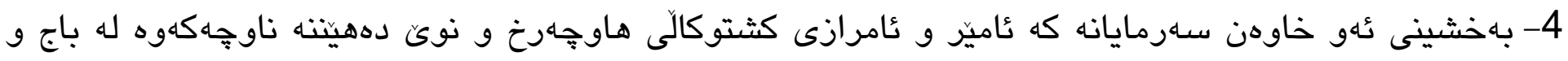

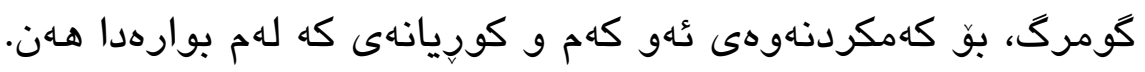

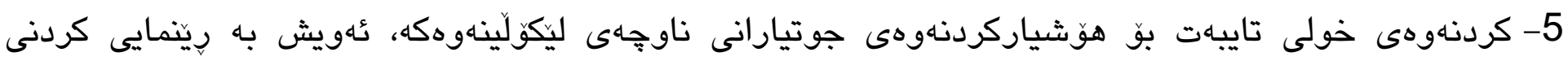

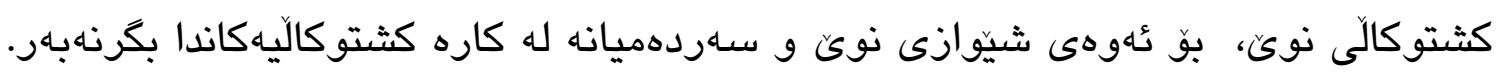

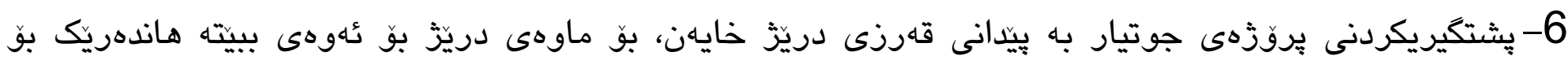
زيادكردنى بارهامى كشتوكالى برنج 


\title{
Suitability Of Pshdar Environment To Yielding Rice
}

\section{Lanja Salah Abdulla}

Geographical Department, Collage of Humanities, University of Sulaimani, Sulaimani, Kurdistan Region, Iraq.

E-mail: Lanja.abdulla@univsul.edu.iq

\begin{abstract}
:
Agriculture Geography is one of the economic Geography branches, agriculture is considered one of the important things that attracted the human attention since their existence which was the cause of the human civilization. Agriculture Geography study the natural phenomena, water, air, soil, and vegetation that cover the earth surface, which is considered as a principle of agriculture production and it may differ from location to another, the agricultural production is a function of the human activities. Knowing the agricultural principles is considered as approve of having human activities within the human geography. This research aims at carrying out an agricultural geography analysis to check the environmental suitability of Pshdar District in producing rice, the investigation has been done in the period 2015 to 2020 . The study has been made on the main resource of food that is consumed by the residents of this district.

Many maps and tables have been used in this research with the aid of numerous references in order to come up with some recommendations, we have concluded that the study area is rich of human and natural resources which can become a very suitable location for rice production if it is paid some attention.
\end{abstract}

Keywords: Rice, Climate, Agriculture, Product, Pshdar District. 


\section{سله رجاومكان}

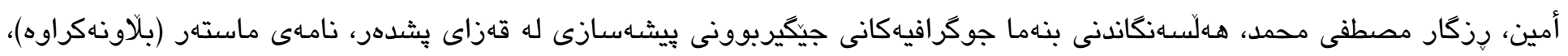

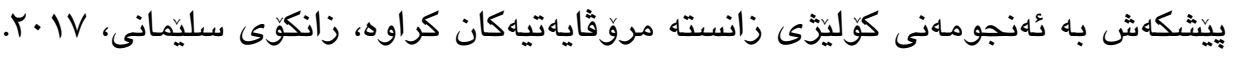

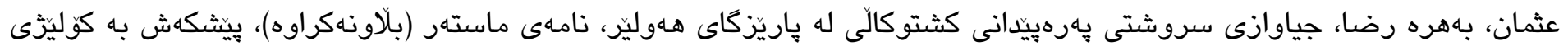

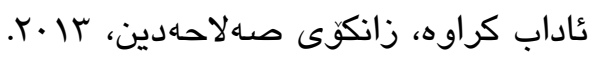

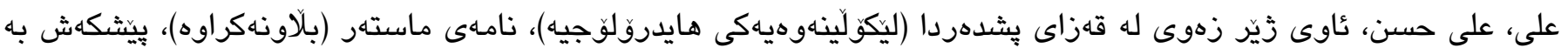
ئهنجومهنى كوليزّى زانسته مروقايهتيهكان كراوه، زانكوى سليمانى، غهفور، عبدالله، جوكرافياى دانيشتوانى كوردستان، جايیى يهكهم، ستوكوَلم، ع199. قارهمان، لهيلا محمد، خاكى هـريّمى كوردستان، جوكرافياى هـهيمى كوردستانى عيّراق، كتيبى سهنتهرى برايهتى، جايخانهى وهزارهتى

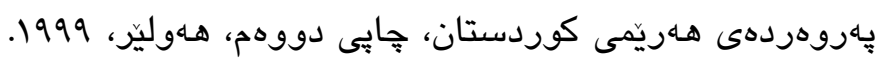
كاكهيى، فهرهيدون، داهات و ئهنى عاو له كوردستاندا، سهنتهرى ليكوَلينهوهى ستراتيجى كوردستان، سليمانى، I...

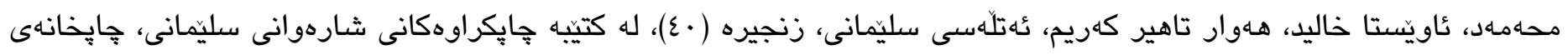
حهمدى، ع.r.

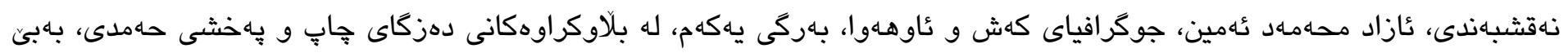

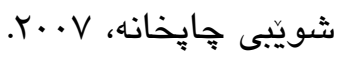
ناصر، سـلام محمود، دهرامهته سروشتيهكان و رِّلّيان له يُرهييّدانى جالاكيه عَابورييهكان له قهزاى يشدهردا، نامهى ماستهر

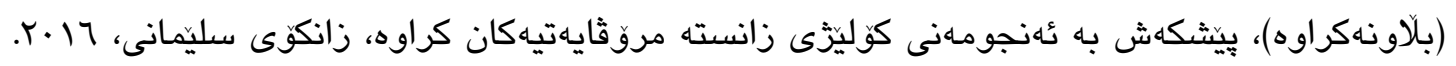

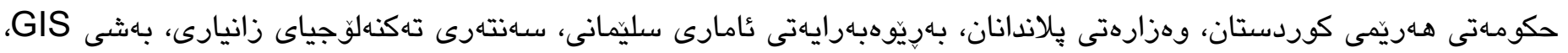

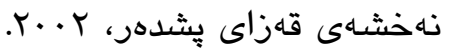


حكومهاتى هـاريّمى كوردستان، وهزارهتى كثتوكال و سهارجاوهكانى ئاو، بهريّوهبهرايهتى بهنداوى دوكان، بهشى كهشناسى، داتاى

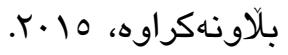

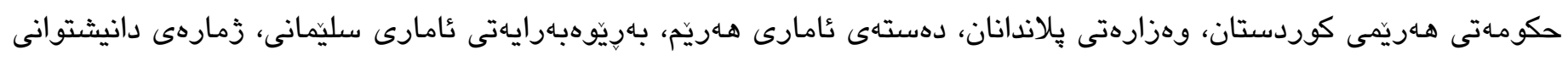

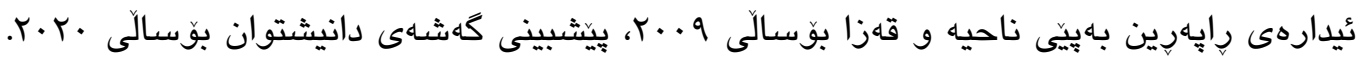
حكومـتى هـاريّمى كوردستان، وهزارهتى ئاوهدانكردنهوه و نيشته جيكردن، بهريّوهبهر ايهتى عاوهدانكردنهوه و نيشته جيكردنى سليمانى،

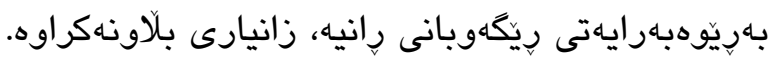

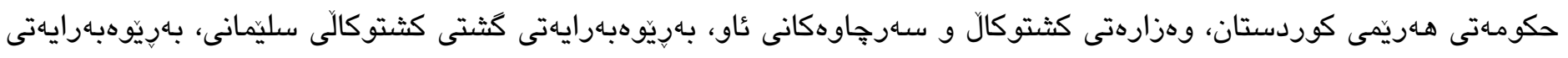

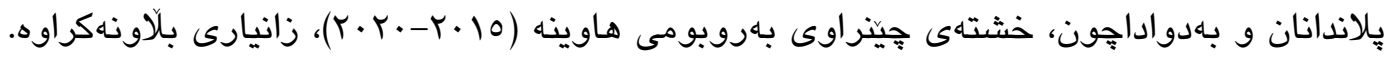

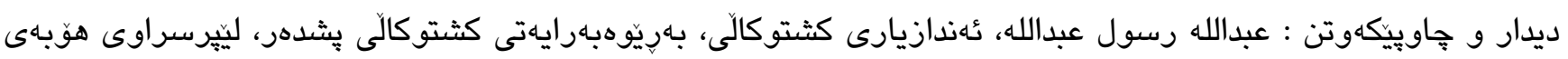

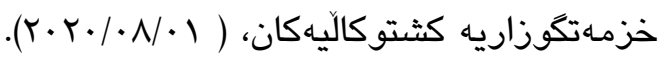
أبو العينين، حسين سيد أحمد، أصول الجغرافية المناخية، الطبعة الأولي، الدار الجامعية للطباعة و النشر، بيروت، ا 91 . ايفانز، ل.ت.، ترجمة فرهاد أحمد أمين، فسيولوجيا المحاصيل، الطبعة الأولي، البيضاء، مطابع المكتب المصري الحديث، ؟9 9 . أحمد، سؤران حمةأمين، التحليل الجغرافي لخصائص الرياح في إقليم كوردستان العراق و إمكانات إستثمارها، رسالة ماجستير (غير منشورة)، مقدمة إلى مجلس كلية العلوم الإنسانية، جامعة السليمانية، 2007. الجنابي، محسن علي أحمد، يونس عبدالقادر علي، المدخل إلي إنتاج المحاصيل الحقلية، بدون مكان الطبع، بدون سنة الطبح. جعفر، سحر أحمد، دراسة كيميائية و ريولوجية لبعض أصناف الرز المزروعة في كوردستان العراق، دبلوم عالي مقدمة إلى مجلس كلية الزراعة، جامعة السليمانية، 2011.

الحساني ، ليث نعيم حسوني ، عمار دحام المعاضيدي ، تأثير مدد الري و التسميد في نمو وحاصل الرز تحت نظام التكيف و الرز (SRI) ، بدون سنة طبع · حمادي ، كاظم عبادي ، تأثير قلة المياه على مستقبل زراعة محصول الرز في العراق ، مجلة البحوث الجغرافية ، العدد الثاني عشر , جامعة ميسان ، بدون سنة طبع 
حبيب، كاظم، دراسات في الإصلاح و التعاون الزراعي الإنتاجي، دار الكتب للطباعة و النشر، جامعة الموصل، 9 I V . خصباك، شاكر، العراق الشمالي، دراسة الجغرافية البشرية (الطبيعة و البشرية)، مطبعة شفيق، الطبعة الأولي، بغداد، 1971. الخفاف، جفرافية السكان أسس عامة، الطبعة الأولي، دار الفكر للطباعة و النشر و التوزيع، عمان، 1999. الزوكة، محمد خميس، جغرافية المياه، دار المعرفة الجامعية، الأسكندرية، 1998 السميع ، محمود بلدر على ، الظروف المناخية وعلاقتها بمرض لفحة الرز (الشري) في محافظة النجف ناحية العباسية ، مجلة القادسية للعلوم الانسانية ، المجلة الحادي عشر ، جامعة الكفة ، بلدون سنة طبع · شريف، عبدالله طريح، الجغرافية المناخية و النباتية، الطبعة الثانية، الناشر: منشأة المعارف بالأسكندرية، مصر، 1985. شفيق، صلاح الدين عبدالرزاق شفيق، عبدالحميد السيد الدبابي، إنتاج محاصيل الحقل، الطبعة الأولى، دار الفكر العربي، 2008. العاني، خطاب صكار، الجغرافية الإقتصادية، الطبعة الثانية، مطبعة دار التضامن، بغداد، 1969. العاني، خطاب صكار، جغرافية العراق أرضا و سكانا و موارد إقتصادية، دار الحكمة للطباعة و النشر، جامعة بغداد، 1988. عيسى، ناظم أنيس، جغرافية التربة، منشورات جامعة دمشق، مطابع دار البعث، 2013-2014. عيسى، صالحة مصطفى، الجغرافية المناخية، الطبعة الأولى، مكتبة المجتمع العربي للنشر و التوزيع، عمان، 2006. غالب، سعدي علي، جغرافية النقل و التجارة، مديرية دار الكتب للطباعة و النشر، جامعة الموصل، 1987. قفطان، محمد فاضل محمد عزيز، التنمية الإقتصادية، الطبعة الأولى، مطبعة الحوادث، بغداد، 1984. صافيتا، محمد و آخرون، جغرافية الزراعة، دار الكتب للطباعة و النشر، الموصل، 2003. الصائي ، حميد ، وأخرون ، الأسس العلمية للتسويق الحديث ، دار اليازورى العلمية للنشر و التوزيع ، عمان ، 2007 . كذلك، محمد محمد، زراعة الأرز، الطبعة الأولى، طبع مركز دلتا، بدون مكان الطبع، 2000. كربل، عبدالأله رزوقي، ماجد السيد ولي محمد، علم الطقس و المناخ، مطبعة جامعة البصرة، البصرة 1986. 
محمد، آرام عباس، تأثير الكثافة النباتية و طريقتين للزراعة في صفات النمو و الحاصل لأربعة أصناف محلية من الرز (Oryza Sative L) في منطقة السليمانية، رسالة ماجستير مقدمة إلى مجلس كلية الزراعة، جامعة السليمانية، 2002. محمد ، كرديم دراغ ، أقليم زراعة الرز في محافظتي النجف والقادسية ، مجلة البحوث الجغرافية ، العدد (19 ) ، جامعة الكفة ، بدون سنة طبع · مرعى، مخلف الشلال، إبراهيم محمد حسون، جغرافية الزراعة، جامعة الموصل، 1961. مرسي، مصطفى علي، عبدالعظيم عبدالجواد، محاصيل الحقل، الطبعة الأولى، دار الهنا للطباعة، مصر، 1961. النجفي ، سالم توفيق ، اسماعيل عبيد حمادي ، التخطيط الزراعي ( التخطيط التنمية و السياسية الزراعة ) ، مديرية دار الكتب للطباعة والنشر ، الموصل 1989، اليونس، عبدالحميد أحمد، إنتاج و تحسين المحاصيل الحقلية، دار الكتب للطباعة و النشر، بغداد، 1993. اليونس، عبدالحميد أحمد، وفقي شاكر الشماع، المحاصيل الحقلية و البقولية-المرشد العلمي، مؤسسة دار الكتب للطباعة و النشر، بدون سنة طبع. السنة الدولية للارز ، (FAO) ، 2004 ( ) .

حكومة إقليم كوردستان، مديرية إحصاء السليمانية، المؤشرات السكانية و البنى الخدمية الإرتكازية لإقليم كوردستان العراق، لسنة 2002، محافظة السليمانية 2003، غير منشورة 